\section{Pacific Northwest}

\section{- National Laboratory}

Operated by Battelle tor the U.S Department of Energy

\title{
Low-Activity Waste Feed Data Quality Objectives
}

\author{
M.J. Truex \\ K.D. Wiemers

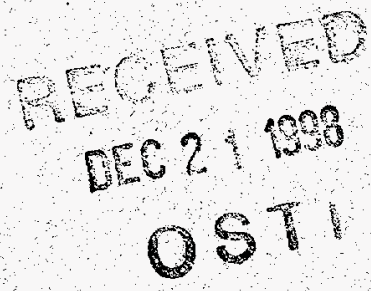

December 1998

Prepared for the U.S. Department of Energy under Contract DE-AC06-76RLO 1830 


\title{
DISCLAIMER
}

This report was prepared as an account of work sponsored by an agency of the United States Government Neither the United States Government nor any agency thereof, nor Battelle Memorial Institute, nor any of their employees, makes any warranty, express or implied, or assumes any legal liability or responsibility for the accuracy, completeness, or usefulness of any information, apparatus, product, or process disclosed, or represents that its use would not infringe privately owned rights. Reference herein to any specific commercial product, process, or service by trade name, trademark, manufacturer, or otherwise does not necessarily constitute or imply its endorsement, recommendation, or favoring by the United States Government or any agency thereof, or Battelle Memorial Institute. The views and opinions of authors expressed herein do not necessarily state or reflect those of the United States Government or any agency thereof.

\author{
PACIFIC NORTHWEST NATIONAL LABORATORY \\ operated by \\ BATTELLE \\ for the \\ UNITED STATES DEPARTMENT OF ENERGY \\ under Contract $D E-A C 06-76 R L O 1830$
}

Printed in the United States of America

Available to DOE and DOE contractors from the

Office of Scientific and Technical Information, P.O. Box 62, Oak Ridge, TN 37831; prices available from $(615) 576-8401$.

Available to the public from the National Technical Information Service, U.S. Department of Commerce, 5285 Port Royal Rd,, Springfield, VA 22161 


\section{DISCLAIMER}

Portions of this document may be illegible in electronic image products. Images are produced from the best available original document. 
Low-Activity Waste Feed Data Quality Objectives

M.J. Truex

K.D. Wiemers

December 1998

Prepared for

the U.S. Department of Energy

Under Contract DE-AC06-76RLO 1830

Pacific Northwest National Laboratory Richland, Washington 99352 


\section{Contents}

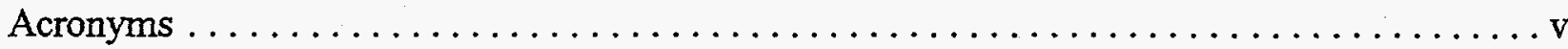

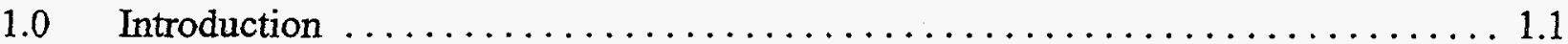

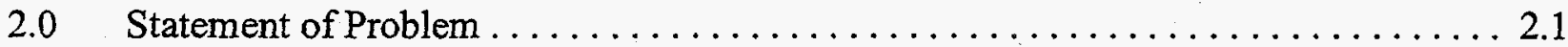

3.0 Decisions/Questions and Data Inputs $\ldots \ldots \ldots \ldots \ldots \ldots \ldots \ldots \ldots \ldots \ldots \ldots \ldots \ldots \ldots \ldots$

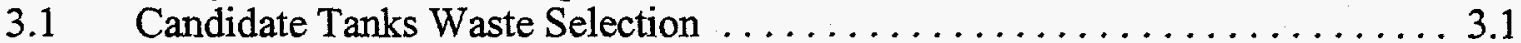

3.2 LAW Treatment Facility Process Development and Plant Design . . . . . . . 3.2

3.2 .1 Pretreatment ................................. 3.3

3.2.2 Immobilization . . . . . . . . . . . . . . . . . . . . . . . . . . 3.6

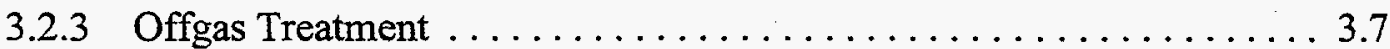

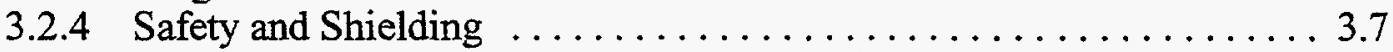

3.3 ILAW Storage/Disposal Facility Design $\ldots \ldots \ldots \ldots \ldots \ldots \ldots \ldots \ldots .8$

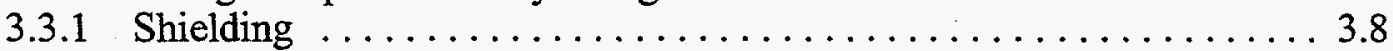

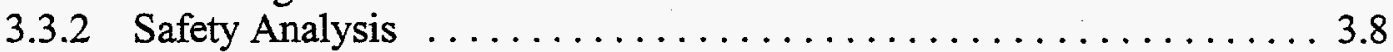

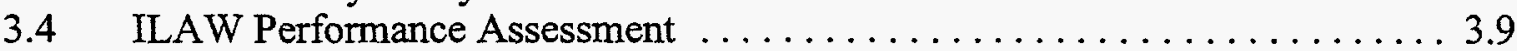

$3.5 \quad$ NRC Guidelines for Incidental Waste $\ldots \ldots \ldots \ldots \ldots \ldots \ldots \ldots \ldots \ldots .11$

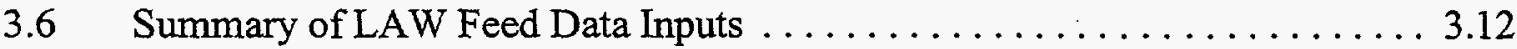

3.7 DQO Decision Logic Implementation $\ldots \ldots \ldots \ldots \ldots \ldots \ldots \ldots \ldots \ldots \ldots \ldots \ldots \ldots \ldots$

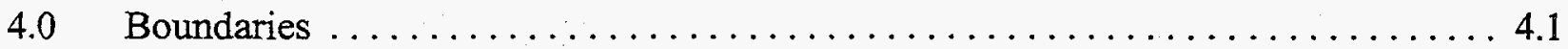

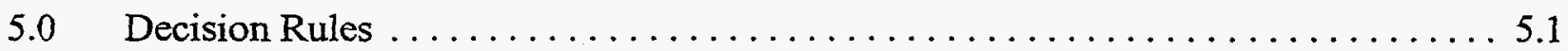

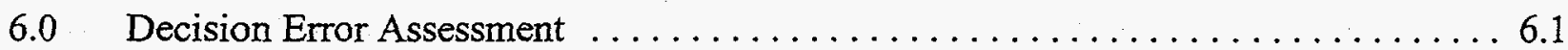

6.1 Consequences of an Incorrect Decision $\ldots \ldots \ldots \ldots \ldots \ldots \ldots \ldots \ldots .1$

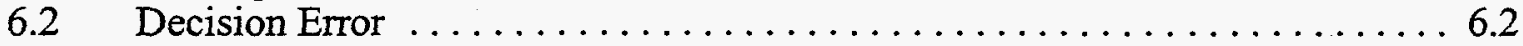

6.2 .1 Number of Samples $\ldots \ldots \ldots \ldots \ldots \ldots \ldots \ldots \ldots \ldots \ldots . .6 \ldots \ldots \ldots$

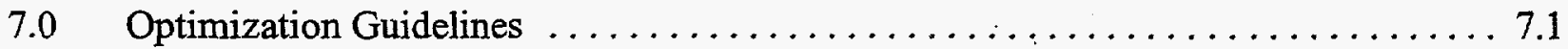

$7.1 \quad$ Planning Assumptions $\quad \ldots \ldots \ldots \ldots \ldots \ldots \ldots \ldots \ldots \ldots \ldots \ldots \ldots \ldots, 1$

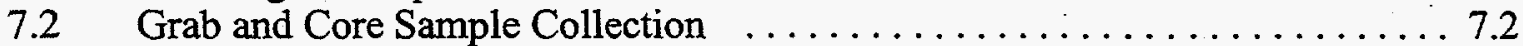

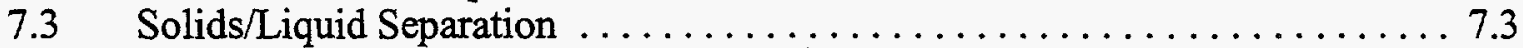

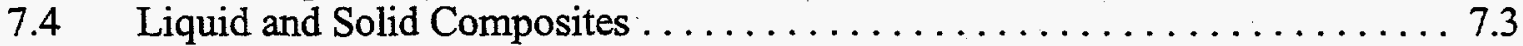

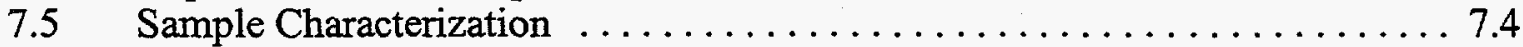

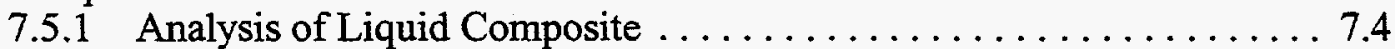

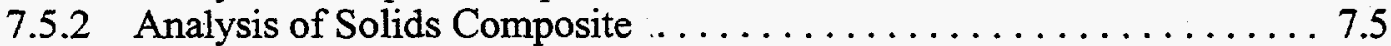

7.5.3 Solids Solubility Screening $\ldots \ldots \ldots \ldots \ldots \ldots \ldots \ldots \ldots . \ldots \ldots$

7.6 Project-Specific Analytical Quality Assurance

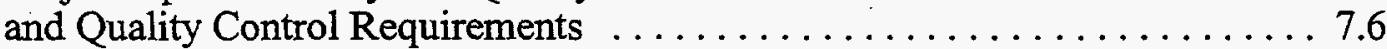

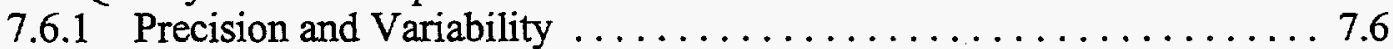

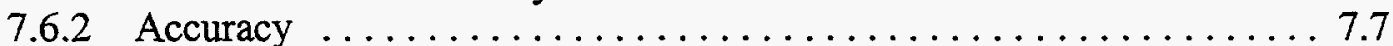

7.6.3 Laboratory Control Standard $\ldots \ldots \ldots \ldots \ldots \ldots \ldots \ldots \ldots \ldots \ldots . . \ldots \ldots$

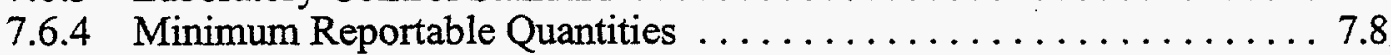


7.7 Data Reduction Methodology and Reporting $\ldots \ldots \ldots \ldots \ldots \ldots \ldots . . \ldots$

7.7.1 Laboratory Assessment and Report ................... 7.9

7.7.2 Statistical Approach, Treatment of the Data, and Report ....... 7.10

$8.0 \quad$ References. $\ldots \ldots \ldots \ldots \ldots \ldots \ldots \ldots \ldots \ldots \ldots \ldots \ldots \ldots \ldots . .1$

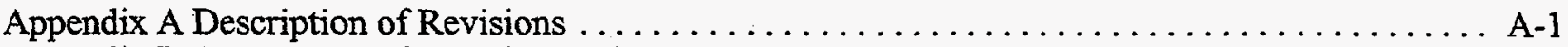

Appendix B Assessment of Sample Number Based on Sample Mean $\ldots \ldots \ldots \ldots \ldots \ldots \ldots \ldots$. B-1

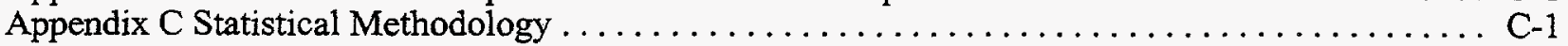

\section{Figures}

1.1 A Strategy for TWRS Privatization Feed Characterization $\ldots \ldots \ldots \ldots \ldots \ldots \ldots \ldots$

3.1 DQO Interfaces for ILAW Phase I Flowsheet ........................ 3.16

3.2 Generic Process Flowsheet for Private Contractor LAW Service . . . . . . . . . . . 3.17

3.3 TWRS Privatization LAW DQO Decision Logic $\ldots \ldots \ldots \ldots \ldots \ldots \ldots \ldots \ldots \ldots \ldots$

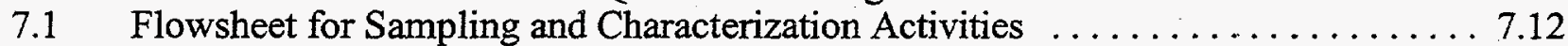

7.2 Sampling Strategy for TWRS Privatization Candidate LAW Feed Source Tank . . . 7.13

\section{Tables}

3.1 Group 1 List and Corresponding Contract LAW Feed

Specification Envelope Limits ............................ 3.21

3.2 Group 1 Radionuclides Versus Reason for Data Collection .............. 3.22

3.3 Group 1 Chemical Analytes and Physical Properties

Versus Reason for Data Collection $\ldots \ldots \ldots \ldots \ldots \ldots \ldots \ldots \ldots \ldots \ldots . . \ldots \ldots . .23$

3.4 Group 2 Radionuclides Versus Reason for Data Collection ................. 3.24

3.5 Group 2 Chemical Analytes and Physical Properties Versus

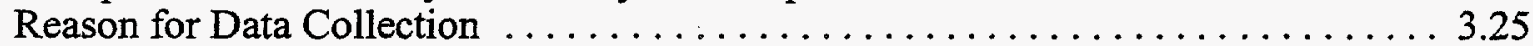

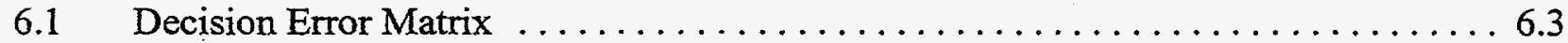

7.1 Quality Control Parameters ................................. 74

7.2 Rules for Determining Accuracy Requirements for ILAW Performance Assessment Data . . . . . . . . . . . . . . . . . . 7.17

7.3 Average Tank Concentration and Estimated Detection Limits for ILAW Performance Assessment Analyte Measurements . . . . . . . . . . . . 7.18

7.4 Minimum Reportable Quantities ............................... 7.19 


\section{Acronyms}

AEA

BBI

CVAA

DOE

DST

DQO

Ecology

EPA

EQL

GC/MS

GEA

$\mathrm{H}_{\mathrm{a}}$

HASQARD

HDW

HLW

$\mathrm{H}_{0}$

HTCE

IC

ICD

ICP

IHLW

ILAW

ISE

LAW

LCS

MDA

MRQ

MS

NRC

PA

PHMC

PNNL

PQL

QA

QC

RCRA

RPD

RSD

SST

TCLP

TCR

TIC

TOC

TPA alpha energy analysis

Best Basis Inventory

cold vapor atomic absorption

US Department of Energy

double-shell tank

data quality objective

Washington State Department of Ecology

US Environmental Protection Agency

estimated quantitation limit

gas chromatography/mass spectrometry

gamma energy analysis

alternate hypothesis

Hanford Analytical Services Quality Assurance Requirements Documents

Hanford Defined Waste

high-level waste

null hypothesis

Historical Tank Content Estimate

Ion chromatography

Interface Control Document

inductively coupled plasma.

immobilized high-level waste

immobilized low-activity waste

ion selective electrode

low-activity waste

laboratory control standard

minimum detectable activity

minimum reportable quantities

mass spectroscopy

US Nuclear Regulatory Commission

performance assessment

Project Hanford Management Contract

Pacific Northwest National Laboratory

practical quantitation limit

quality assurance

quality control

Resource Conservation and Recovery Act of 1976

relative percent difference

relative standard deviation

single-shell tank

toxicity leachate characteristic procedure

tank characterization report

total inorganic carbon

total organic carbon

Tri-Party Agreement (also known as the Hanford Federal Facility Agreement and Consent Order 
TRU

TWINS

TWRS

TWRSOUP

vol\%

$w t \%$ transuranic

Tank Waste Information Network System

Tank Waste Remediation System

Tank Waste Remediation System Operation and Utilization Plan volume percent

weight percent 


\subsection{Introduction}

This document describes characterization requirements for the Tank Waste Remediation System (TWRS) Waste Disposal Program's privatization efforts in support of low-activity waste (LAW) treatment and immobilization. This revised Data Quality Objective (DQO) replaces earlier documents (PNNL 1997; DOE-RL 1998a; Wiemers 1996). Revision 0 of this DQO was completed to meet Tri-Party Agreement (TPA) target milestone M-60-14-T01. Revision 1 updates the data requirements based on the contract issued August 1998 (DOE-RL 1998b). In addition, sections of Revision 0 pertaining to "environmental planning" were not acceptable to the Washington State Department of Ecology (Ecology) and have been

removed. Regulatory compliance for TWRS Privatization is being addressed in a separate DQO (Wiemers et al. 1998). The Project Hanford Management Contract (PHMC) Contractors and the private contractor may elect to complete issue-specific DQOs to accommodate their individual work scope.

A description of the candidate waste feed selection process is updated and published in the Tank Waste Remediation System Operation and Utilization Plan (TWRSOUP) (Kirkbride et al. 1997). The characterization requirements outlined in this DQO document apply to tank samples from the candidate Phase I LAW source tanks. These have been identified as tanks AN-102, AN-103, AN-104, AN-105, AN-107, AW-101, AZ-101 (supernate), AZ-102 (supernate), and SY-101.

Additional characterization of the LAW feed will be performed in the intermediate feed staging tanks. Characterization requirements for the intermediate feed staging tanks will be identified in other DQOs consistent with the Feed Certification Plan, Interface Control Document (ICD) 19, and Waste Acceptance Plan. This DQO does not cover characterization for treatment of the waste.

The purpose of this DQO is to provide data to accomplish the following:

- update waste charaterization information from source tanks to provide an independent assessment that the feed specification and ICD are adequate for DOE's management of the site M\&I contractor and BNFL contracts

- provide preliminary information for contractor process and facility designs

- provide preliminary information for immobilized low-activity waste (ILAW) storage and disposal design/specifications

- support update of the ILAW performance assessment (PA) for disposal

- help substantiate the ability to comply with US Nuclear Regulatory Commission (NRC) guidelines for incidental waste.

An overview of the TWRS Privatization Program and more detailed information on this DQO are provided below.

The TWRS Program was established in 1991 to manage, retrieve, treat, immobilize, and dispose of radioactive wastes stored at the Hanford Site in a safe, environmentally sound, and cost-effective manner. The US Department of Energy (DOE) believes it is feasible to privatize portions of the TWRS Program 
associated with waste treatment and waste immobilization. In DOE's privatization strategy, services will be purchased from a contractor-owned, contractor-operated facility under a fixed-price contract. Currently, DOE has initiated Phase I of a two-phase acquisition strategy to remediate Hanford Site Tank Waste.

Phase I of the TWRS Privatization strategy is the initial processing phase. The objectives of Phase I are as follows:

- demonstrate the technical and financial viability of using privatized facilities to treat Hanford Site tank waste

- define and maintain required levels of radiological, nuclear, process, and occupational safety

- maintain environmental protection and compliance

- process approximately $10 \%$ of the Hanford tank waste by mass and $20 \%$ to $25 \%$ by radioactivity.

Phase II of the TWRS Privatization strategy is a full-scale production phase in which the facilities are provided to retrieve, treat, and immobilize the remaining wastes from the single-shell and double-shell tanks (SSTs and DSTs).

During Phase I, the DOE is planning to procure services to treat LAW from a private contractor. Three waste feed streams for the LAW facility are defined in the TWRS Privatization Contract (DOE-RL 1998b) (hereafter referred to as Privatization Contract). These feed streams, referred to as Envelopes A, B, and $\mathrm{C}$, are high-level waste (HLW) supernates that will require pretreatment to remove radioactive material before conversion to an ILAW form. The $\mathrm{HLW}$ supernates include the following radionuclides: ${ }^{137} \mathrm{Cs}$, ${ }^{99} \mathrm{Tc}$, transuranics (TRU), ${ }^{90} \mathrm{Sr}$ and other radionuclides. The three waste feed envelopes were designed to test different requirements of the Hanford Site immobilization effort.

- Envelope A waste feed will test plant production capacity and fission product removal efficiency and will produce a final product in which the waste loading is expected to be limited by sodium.

- Envelope B waste feed is similar to Envelope A, except that the waste loading in the final product should be limited by minor component concentrations. In addition, high concentrations of ${ }^{137} \mathrm{Cs}$ in the feed will require more extensive removal.

- Envelope $C$ represents waste feed with organic complexing agents and will require removal of ${ }^{90} \mathrm{Sr}$ and/or TRU.

During Phase I, the PHMC contractor will stage feed that meets the contract envelope specifications. Waste will be retrieved from a source tank and transferred to intermediate feed staging tanks before delivery to the private contractor feed tank (Figure 1.1) (Kirkbride et al. 1997). The waste is mixed, resampled, and analyzed, and adjustments are made in the intermediate feed staging tank. The waste is classified with respect to Privatization Contract specifications by the DOE before transfer to the staging tank. This strategy provides a schedule contingency that may be used to mitigate delays caused by retrieval difficulties, transfer difficulties, chemical adjustment requirements, or restaging of an out-of-specification 
feed batch. The first feed batch must be staged in private contractor's feed tanks by the completion of the private contractor's designs, construction, and testing activities. The DOE is committing to provide the feed and BNFL is to receive the feed no later than July 2006. At the latest; feed staging will begin in advance of that date in the 2004 time frame.

Due to the contractual issues and proprietary processes, the representatives of the private contractor were not physically present during this $\mathrm{DQO}$ process. The DOE obtained the contractor input in parallel with the DQO process. This input was incorporated similarly to other draft technical input and does not necessarily have traceability to formal transmittal records. The private contractor has not provided detailed design information for waste processing at this time. The assessment of the data inputs are based on the data needs submitted by the private contractor, Privatization Contract specifications, and the DOE's understanding of the processes to be used by the private contractor in their treatment facilities. The primary purpose of the planning data is to assist DOE in the management of the private contractor and PHMC contracts before a design freeze in the private contractor's facility tentatively scheduled in August 2000.

This DQO update was implemented in accordance with the TWRS DQO process (Banning 1997) with some activities and/or steps modified to accommodate TWRS Privatization Project-specific requirements. This document will be revised as new information warrants. Representatives from the TWRS Privatization Treatment Facility Contractor were not present during this DQO process. The DOE obtained the contractor input in parallel with the DQO process due to contractual issues and proprietary processes. This input was incorporated similarly to other draft technical input and does not necessarily have traceability to formal transmittal records. 


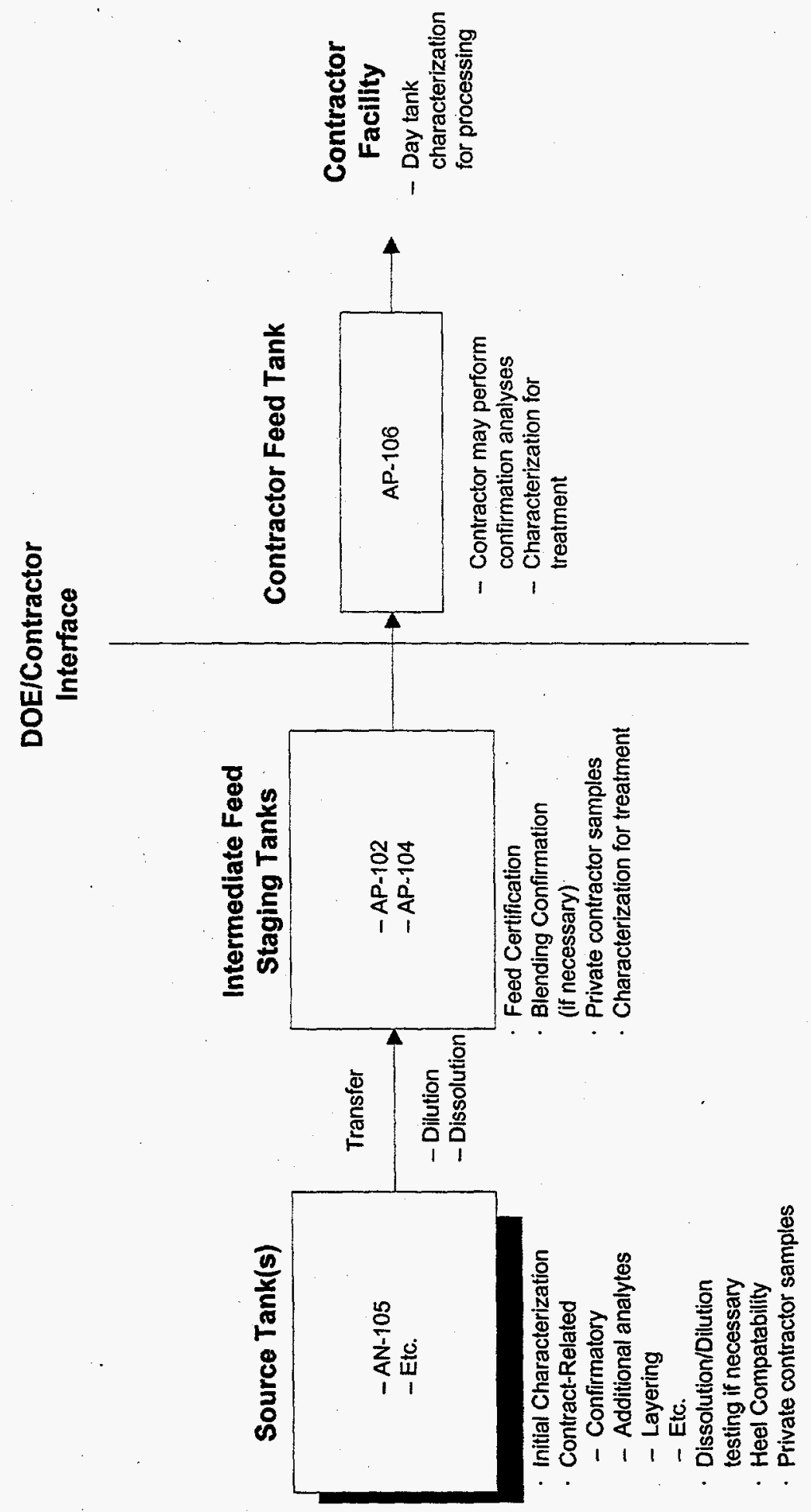

Figure 1.1. A Strategy for TWRS Privatization Feed Characterization 


\subsection{Statement of Problem}

The DOE must ensure that minimum quantities of LAW feed can be delivered on schedule within the compositional limits defined in the Privatization Contract. Early selection of the tank waste feeds will be required to satisfy this commitment. The compositional entities included in LAW feed envelope specifications were selected based on technology demonstration requirements and the availability of characterization information. Additional information is required where characterization information may be insufficient to supplement early process flowsheet and facility design studies. Refined problem statements may be required after DOE's authorization to proceed (August 1998).

Additional data requirements defined in this DQO will accomplish the following:

- update waste characterization information from source tanks to provide an independent assessment that the feed specification and ICD are adequate for DOE's management of the site M\&I contractor and BNFL contracts,

- provide preliminary information for contractor process and facility designs (e.g., provide data to support preparation of proper mobilization, retrieval, and the dilution waste/caustic additions systems in time to support LAW feed staging; support process flowsheet development and facility conceptual design studies),

- provide preliminary information for ILAW storage and disposal design/specifications,

- support update of the ILAW PA for disposal,

- help substantiate the ability to comply with NRC guidelines for incidental waste.

Data required for TWRS Privatization regulatory compliance is addressed in a separate DQO (Wiemers et al. 1998). 


\subsection{Decisions/Questions and Data Inputs}

The DQO process identified information to support the following TWRS Privatization Phase I LAW activities:

1. verification of applicable feed from candidate tank wastes for Phase I Envelopes A, B and C feed

2. completion of the private contractor's treatment facility's design planning phase and development/testing of waste treatment and immobilization technologies

3. completion of the ILAW storage/disposal facility design planning phase

4. update of the ILAW disposal system PA

5. adherence to NRC incidental waste guidelines.

The interface of these activities with the overall TWRS Privatization Project is shown schematically in Figure 3.1. Decisions, questions, and data inputs specific to activities 1 through 5 are described in Sections 3.1 through 3.5. In each Section, specific data requirements generated from the activity are highlighted for those analytes that are not in the Privatization Contract specifications. Data requirements are also summarized in Tables 3.1 through 3.5. Note that the NRC guidelines for incidental waste is applicable to multiple stages of the project but are addressed separately in Section 3.5. A summary of the LAW data inputs is provided in Section 3.6. The overall decision logic for implementing this DQO is described in Section 3.7. A comparison between the previous (PNNL 1997; DOE-RL 1998a; and Wiemers 1996) and revised data inputs lists is presented in Appendix A.

The sampling and characterization implemented as a result of this DQO will be used for planning. As a result, a majority of the alternative actions fall into two major categories: either the DOE contract is renegotiated or the process/facility designs are adjusted to accommodate increased capacity requirements, new technologies, additional waste stream volumes, etc. Impacts to the DOE are reduced when the need for these fallback positions are realized or eliminated early in the planning process. Data required to characterize source tank waste with respect to Resource Conservation and Recovery Act of 1976 (RCRA) requirements and corresponding state requirements are addressed in a separate DQO (PNNL 1998).

\subsection{Candidate Tanks Waste Selection}

The DOE must be assured that the LAW feed compositional limits provide a workable balance between what can be delivered by the PHMC and what can be processed by the private contractor consistent with the Privatization Contract product specifications. The LAW feed envelope limits are listed in Table 3.1. Additional background for the technical basis of the Privatization Contract analytes and properties is available in Patello and Wiemers (1996) and Galbraith (1996). An initial screening of target waste composition will be used as a basis for DOE contract management and the PHMC selection of 
candidate waste. Confirmation of tank waste candidates, requirements for waste retrieval, mobilization, and transfer, will be addressed in other DQOs.

\subsection{LAW Treatment Facility Process Development and Plant Design}

The decisions/questions for planning and trade studies related to the private contractor's treatment facility's design and operation are based on information currently known by the DOE about the potential treatment processes. Figure 3.2 provides a generic process flowsheet for the private contractor's LAW treatment facilities. Figure 3.2 and information in this DQO do not present contractor-specific information that may be proprietary. The treatment process for the LAW will entail multiple unit processes. Each process unit will require its own set of characterization data to enable the operators to maximize process efficiencies. Data inputs for the DQO were based on the best available information about the LAW treatment facilities design. It is assumed that the final selection for processes occurred in the BNFL Part B-1 contract. However, this doesn't preclude the need to identify new data needs in response to adjustments to the design over time.

The following assumptions were used in defining the data inputs for the private contractor:

- Feed and product contractual specifications are met.

- Treatment processes have the potential to change the presence or concentration of a critical constituent. Process streams and operating conditions will be monitored through additional measurements/analysis to support process control. This DQO does not include process control data needs.

- The LAW treatment facility unit processes are listed as follows:

- solid/liquid separation

- strontium/TRU removal

- cesium removal

- technetium removal
- feed preparation

- immobilization

- offgas treatment

- Physical properties such as particle size distribution, density of solids, settling properties, filterability and viscosity of the medium are important to the design of waste feed transfer, homogenization, solids separation and ion exchange systems. These properties are expected to change with mobilization, retrieval, and solids separation activities. These properties are identified as a data input for each applicable unit process; however, characterization is deferred to other DQOs that more specifically address mobilization and retrieval activities. Physical property measurements deferred to future DQOs are shown in brackets in the text below.

For discussion purposes, the waste treatment unit processes are divided into four categories: pretreatment, immobilization, offgas treatment, and safety and shielding. Questions for each unit are discussed in Sections 3.2.1 through 3.2.4, along with the data inputs and justifications for gathering these data. 


\subsubsection{Pretreatment}

Pretreatment includes solid/liquid separation and concentration steps in preparation for downstream processing and removal of radionuclides to meet product specifications. Questions, data inputs, and justification relevant to each of these unit processes are given below:

\subsubsection{Solid/Liquid Separation.}

Question 1a: Does solids concentration exceed 2 weight percent (wt\%) of the waste transferred?

Question 1b: $\quad$ Does composition and physical properties of the solids, cause operational problems?

Question 1c: $\quad$ Is there soluble $\mathrm{Na}$ in the entrained solids?

Question 1d: What fraction of the solids are soluble? Insoluble?

Question 1e: What are the solid component concentrations with respect to the disposition of the solids after solid/liquid separation?

Data Inputs: $\quad$ solids content (volume and weight) as is, diluted, and washed, composition of solids including $\mathrm{Na}, \mathrm{Al}, \mathrm{Cr}, \mathrm{P}, \mathrm{S}, \mathrm{OH}$, total inorganic carbon (TIC), total organic carbon (TOC), Si, total alpha, ${ }^{90} \mathrm{Sr},{ }^{137} \mathrm{Cs},{ }^{60} \mathrm{Co},{ }^{154 / 155} \mathrm{Eu}$, Privatization Contract Specification 1 oxide components ( $\mathrm{Fe}, \mathrm{Al}, \mathrm{Na}, \mathrm{K}, \mathrm{Zr}, \mathrm{U}, \mathrm{Ca}, \mathrm{Mg}, \mathrm{Ba}$, $\mathrm{Cd}, \mathrm{Ni}, \mathrm{Pb}, \mathrm{Ti}, \mathrm{Bi}, \mathrm{P}, \mathrm{F}, \mathrm{Cr}, \mathrm{S}, \mathrm{Ag}, \mathrm{Rh}, \mathrm{Ru}, \mathrm{Pd}$ ), and Privatization Contract Specification 7 supernate analytes $(\mathrm{Al}, \mathrm{Ba}, \mathrm{Ca}, \mathrm{Cd}, \mathrm{Cl}, \mathrm{Cr}, \mathrm{F}, \mathrm{Fe}, \mathrm{Hg}, \mathrm{K}, \mathrm{La}, \mathrm{Ni}$, $\mathrm{NO}_{2}, \mathrm{NO}_{3}, \mathrm{~Pb}, \mathrm{PO}_{4}, \mathrm{SO}_{4}$ TIC, TOC, U, TRU components, ${ }^{90} \mathrm{Sr},{ }^{137} \mathrm{Cs},{ }^{60} \mathrm{Co}$, ${ }^{154 / 155} \mathrm{Eu},{ }^{99} \mathrm{Tc}$ ) [parameters related to solid/liquid separations operations such as particle size distribution, density of solids, and viscosity of waste feed] 
Justification: The Privatization Contract establishes a maximum insoluble solids content for the LAW feed. Suspended solids in the source tank could include constituents that impact the supernate composition relative to the subsequent treatment steps. The private contractor is required to meet the entrained solids specifications for return of any entrained solids (i.e., entrained solids that are not processed in LAW or HLW fractions). The delivered solids may contain soluble $\mathrm{Na}$, which may need to be reconciled for payment for LAW services. In either case, the DOE and the private contractor will need to know the composition of the solids for estimating solids management requirements. In addition, the composition of the solids can impact the disposition of the solids after separation. The separated solids may either be incorporated into ILAW, immobilized high-level waste (IHLW), or returned to the DOE, in which case it would require interim storage in a DST and potentially have a significant cost/logistics impact to the DOE. Analytes associated with the Privatization Contract specifications for supernate concentrations are needed in the solids to determine mathematical tank composite concentration and to aid in up-front assessment of the disposition of solids from the solid/liquid separation portion of the treatment process. Analytes associated with component limits in the IHLW are needed to aid in up-front assessment of the disposition of solids from the solid/liquid separation portion of the treatment process.

Additional Non- $\quad \mathrm{OH},{ }^{99} \mathrm{Tc}$, TRU components, $\mathrm{Fe}, \mathrm{K}, \mathrm{Zr}, \mathrm{U}, \mathrm{Ca}, \mathrm{Mg}, \mathrm{Ba}, \mathrm{Cd}, \mathrm{Ni}, \mathrm{Pb}, \mathrm{Ti}, \mathrm{Bi}, \mathrm{F}$, Contract Data $\mathrm{Si}, \mathrm{Ag}, \mathrm{Rh}, \mathrm{Ru}, \mathrm{Pd}, \mathrm{Cl}, \mathrm{Hg}, \mathrm{La}, \mathrm{NO}_{2}, \mathrm{NO}_{3}, \mathrm{PO}_{4}$, and $\mathrm{SO}_{4}$ concentrations in the Requirements for this DQO: solids, Solids Solubility Screening Test, correlation with planned retrieval sequences (Note: analytes added to assess solids disposition consist of envelope specification analytes, which are also used in calculating the tank composite concentrations for envelope comparison as described in Section 7.7 and the following additional analytes: $\mathrm{Ag}, \mathrm{Bi}, \mathrm{Mg}, \mathrm{Rh}, \mathrm{Ru}, \mathrm{Si}, \mathrm{Pd}, \mathrm{Ti}, \mathrm{Zr}$.)

\subsubsection{Strontium/TRU and Potential ${ }^{60} \mathrm{Co}$ and ${ }^{154 / 155} \mathrm{Eu}$ Removal.}

Question 2a: Do the concentrations of ${ }^{90} \mathrm{Sr} / \mathrm{TRU}$ radionuclides, competing ions or TOC exceed contract LAW feed specification or

Question 2b: Are other analytes likely to impact process design and planned operations?

Data Inputs: $\quad{ }^{90} \mathrm{Sr}$, TRU, Total Alpha, ${ }^{60} \mathrm{Co},{ }^{154 / 155} \mathrm{Eu}$, total $\mathrm{Sr}$, total $\mathrm{Co}$, total $\mathrm{Eu}, \mathrm{Ba}, \mathrm{Ca}, \mathrm{Cd}$, $\mathrm{Mn}, \mathrm{Ni}$

Justification: $\quad{ }^{90} \mathrm{Sr}$ and TRU must be removed in some waste feeds (Envelope C) to meet product specifications. The Privatization Contracts establish maximum radionuclide contents for the ${ }^{90} \mathrm{Sr} / \mathrm{TRU}$ waste envelopes. Additionally, $\mathrm{Co}$ and Eu may be removed in this unit operation. Potential interfering analytes are competing divalent ions. 
Additional NonContract Data Requirements for this DQO: total $\mathrm{Sr}$, total $\mathrm{Co}$, total $\mathrm{Eu}, \mathrm{Mn}$ concentrations, and Total Alpha in the supernate.

\subsubsection{Cesium Removal.}

Question 3a: $\quad$ Does the concentration of ${ }^{137} \mathrm{Cs}$ and analytes of the same valence state as cesium exceed contract specifications or

Question 3b: $\quad$ are other analytes likely to impact process design and planned operations?

Data Inputs: $\quad{ }^{137} \mathrm{Cs}, \mathrm{Na}, \mathrm{K}$, total $\mathrm{Cs}$, free hydroxide, $\mathrm{TOC}$ [particle size distribution, density of solids, and viscosity of waste feed]

Justification: $\quad{ }^{137} \mathrm{Cs}$ is a major heat and radiation (gamma-emitting) source term. Removal efficiencies affect downstream shielding requirements and the ability to meet product specifications. Cations of the same valence state as cesium $(+1)$ compete for active sites in the ion exchange process. As concentrations of competing analytes increase, the regeneration volumes and frequency also increase. These ions include $\mathrm{Na}$, potassium, and nonradioactive cesium. The Privatization Contracts establish maximum contents for potassium, $\mathrm{Na}$, and ${ }^{137} \mathrm{Cs}$. The hydroxide ion concentration is measured in high ionic strength solutions instead of $\mathrm{pH}$. The $\mathrm{pH}$ affects precipitation of the metals, which can lead to column plugging; therefore, hydroxide concentration is of interest. While the hydroxide ion concentration at the cesium removal step may be different from the ion concentration in the source tank, data for the source tank will be useful for material balance calculations. Some organic carbon and solids in the supernate can cause resin plugging and affect pump design, respectively, but are less critical than the competing ions.

Additional Nontotal $\mathrm{Cs}$ and $\mathrm{OH}$ concentrations in the supernate.

Contract Data

Requirements for this DQO:

\subsubsection{Technetium Removal.}

Question 4a: $\quad$ Do the concentrations of ${ }^{99} \mathrm{Tc}$ or competing anions or TOC exceed contract LAW feed specifications or

Question 4b: Are other analytes likely to impact process design and planned operations?

Data Inputs: $\quad{ }^{99} \mathrm{Tc}$ (total), ${ }^{99} \mathrm{Tc}$ (pertechnetate), nitrite, nitrate, sulfate, phosphate, chloride, fluoride, free hydroxide, TIC, TOC [density/viscosity/particle size and quantity of solids] 
Justification: $\quad$ Total ${ }^{99} \mathrm{Tc}$ must be measured to ensure that the removal efficiencies are adequate to meet product specifications. "Total" is explicit as some analytical methods for ${ }^{99} \mathrm{Tc}$ are oxidation state-dependent, and are not satisfactory for this DQO. ${ }^{99} \mathrm{Tc}$ (pertechnetate) is specified so that the amount of ${ }^{99} \mathrm{Tc}$ that may not be removable by anion exchange can be estimated by computing the difference between total and pertechnetate ${ }^{99} \mathrm{Tc}$ concentrations. Ions that might compete with ${ }^{99} \mathrm{Tc}$ and therefore reduce removal efficiency are nitrite, nitrate, carbonate, sulphate, phosphate, chloride, fluoride, oxalate, formate, acetate and free hydroxide. Excessive anion concentration can also increase regeneration frequency, thus by-product waste volume. The hydroxide ion concentration is measured in high ionic strength solutions instead of $\mathrm{pH}$. The $\mathrm{pH}$ affects precipitation of the metals that can lead to column plugging; therefore, hydroxide concentration is of interest. While the hydroxide ion concentration at the technetium removal step may be different from the concentration in the source tank, data for the source tank will be useful for material balance calculations. Some organic carbon and solids in the supernate can cause resin plugging and affect pump design, respectively, but are less critical than the competing ions.

Additional Non${ }^{99} \mathrm{Tc}$ (pertechnetate) and $\mathrm{OH}$ concentrations in the supernate.

Contract Data

Requirements for this DQO:

\subsubsection{Immobilization}

The Privatization Contracts contain specifications that primarily limit the amounts of radionuclides in the ILAW form. In addition, certain constituents can adversely affect the integrity of the immobilized waste package. The questions that are important to waste immobilization, along with their justification, are identified below. For this assessment, feed preparation and immobilization are grouped together. Preparation includes removal of water and the addition of glass formers and reductant before feeding the material to a melter.

Question 5a: Do the concentrations of waste-limiting components or glass formers exceed Privatization Contract LAW feed specifications or

Question 5b: $\quad$ are other analytes likely to impact process design and planned operations?

Data Inputs: $\quad \mathrm{Cl}, \mathrm{F}, \mathrm{P}, \mathrm{S}, \mathrm{Cr}, \mathrm{Na}, \mathrm{K}, \mathrm{Al}, \mathrm{Si}, \mathrm{TOC}, \mathrm{TIC}$, nitrate, nitrite, $\mathrm{Ag}, \mathrm{As}, \mathrm{Ba}, \mathrm{Cd}, \mathrm{Cr}$, $\mathrm{Pb}, \mathrm{Hg}$, and $\mathrm{Se}$ 
Justification: $\quad$ Components ( $\mathrm{Cl}, \mathrm{F}, \mathrm{P}, \mathrm{S}, \mathrm{Cr})$ above threshold levels place limits on waste loading in the vitrified waste form. Solubility can affect product volume and quality. $\mathrm{Na}, \mathrm{K}, \mathrm{Al}$, and $\mathrm{Si}$ may be added as glass formers. These concentrations are expected to be of less importance than the glass-solubility limited constituents. Some constituents may affect glass redox (TOC, nitrate) and feed preparation chemistry (TIC, nitrite). Metals defined in 40 CFR 261.24 (Ag, As, Ba, Cd, Cr, Hg, Pb, Se) can affect waste loading with respect to passing toxicity characteristic leachate procedure (TCLP) requirements.

Additional Non- $\quad \mathrm{P}, \mathrm{S}, \mathrm{Si}, \mathrm{Ag}, \mathrm{As}$, and $\mathrm{Se}$ in the supernate

Contract Data

Requirements for this DQO:

\subsubsection{Offgas Treatment}

For the purpose of this assessment, the offgas released from individual process units is treated as a single output stream. The offgas treatment includes both air emissions and a liquid effluent waste stream. Regulated organics that may be of concern for emissions are addressed in the Regulatory DQO

(Wiemers et al. 1998).

Question 6a: Do the concentrations of volatile components exceed contract LAW feed specifications or

Question 6b: are other analytes likely to impact process design and planned operations?

Data Inputs: $\quad \mathrm{S}, \mathrm{Cl}, \mathrm{F}, \mathrm{TIC}, \mathrm{TOC}$, nitrite, nitrate, $\mathrm{NH}_{4},{ }^{3} \mathrm{H},{ }^{14} \mathrm{C},{ }^{129} \mathrm{I}$, Total Alpha

Justification: The contract LAW feed specification establishes an upper limit for all analytes identified as data inputs except $\mathrm{NH}_{4},{ }^{3} \mathrm{H},{ }^{14} \mathrm{C}, \mathrm{S}$, and ${ }^{129} \mathrm{I}$. Exceeding contract limits could result in emissions that require further treatment to meet permitting requirements or effluent specifications. Additional limits will be established by the private contractor in permits regulated by the Washington State Department of Ecology (Ecology).

Additional Non- $\quad \mathrm{NH}_{4},{ }^{3} \mathrm{H},{ }^{14} \mathrm{C}, \mathrm{S},{ }^{129} \mathrm{I}$ concentrations, and Total Alpha in the supernate.

Contract Data

Requirements for this DQO:

\subsubsection{Safety and Shielding}

A detailed analysis of the safety and shielding requirements for the treatment facility is not currently available. At a minimum, the safety and shielding data inputs identified in Section 3.3 are applicable. Higher concentrations of ${ }^{137} \mathrm{Cs},{ }^{90} \mathrm{Sr},{ }^{60} \mathrm{Co},{ }^{154 / 155} \mathrm{Eu}$, and ${ }^{125} \mathrm{Sb}$ will affect treatment facility design. Isotopes relevant to criticality analysis are ${ }^{233} \mathrm{U},{ }^{235} \mathrm{U},{ }^{237} \mathrm{~Np},{ }^{238} \mathrm{Pu},{ }^{239} \mathrm{Pu},{ }^{241} \mathrm{Pu},{ }^{241} \mathrm{Am}$, and ${ }^{243+244} \mathrm{Cm}$. Refined 
problem statements and data inputs may be required after the review of the detailed process technologies and the private contractor's radiological and industrial safety plans.

Additional Non- ${ }^{125} \mathrm{Sb},{ }^{233} \mathrm{U}$, and ${ }^{235} \mathrm{U}$ concentrations in the supernate.

Contract Data

Requirements for

this DQO:

\subsection{ILAW Storage/Disposal Facility Design}

The ILAW will be packaged and transported to a storage/disposal facility. Information gathered during DQO meetings to discuss planning for the ILAW transportation/packaging and storage/disposal facility design are summarized in this section. Two primary drivers were identified: shielding requirements and safety analysis. The PHMC contractor's current strategy is to base planning efforts on the Privatization Contracts' specifications and existing characterization information. No additional characterization needs were identified by the PHMC contractor. The questions and data inputs have been retained in this DQO to support DOE's specification verification and contract management responsibilities. The storage/disposal facility design will also be driven by the ILAW PA (Mann 1998). Performance assessment questions/decisions and data inputs are defined in Section 3.4. Permitting of the storage and treatment facility is not addressed in this DQO.

\subsubsection{Shielding}

Question 7: $\quad$ Are the Privatization Contract specifications for the maximum dose rate on the ILAW package sufficient?

Data Inputs: $\quad{ }^{137} \mathrm{Cs},{ }^{90} \mathrm{Sr},{ }^{60} \mathrm{Co},{ }^{154} \mathrm{Eu}$, and ${ }^{125} \mathrm{Sb}$.

Justification: The specification requires surface dose rate limits for the ILAW product to be $<1,000 \mathrm{mrem} / \mathrm{hr}$. The ILAW must be packaged, transported, and the storage/disposal facility operated to allow handling of the surface dose at the specified levels. It is unlikely that all waste forms will have a $1,000 \mathrm{mrem} / \mathrm{hr}$ surface contact dose rate. If the dose rate is lower, less protection could be required, potentially saving money in design and operation.

Additional Non- $\quad{ }^{125} \mathrm{Sb}$

Contract Data

Requirements for

this DQO:

\subsubsection{Safety Analysis}

The Privatization Contracts provide detailed specifications for the ILAW product packaging, waste loading, package void space, radiological concentration limits, surface dose rate limits, labeling and manifesting, closure/sealing, temperature, free liquids content, radionuclide release rates, toxic gases, 
pyrophoricity, compressive strength, leaching, stability, and handling. The ILAW will be packaged and transported onsite from the private contractor's treatment facility to the storage/disposal facilities. Key factors that influence safety are:

- bounding source terms,

- stability of package contents (no free liquids, pyrophorics, chemical stability, etc.),

- density of the glass (specified and will not vary significantly),

- dimensional and thermal properties, and

- chemical composition impacting corrosion.

Question 8: $\quad$ Are source terms adequately bounded by the Privatization Contracts?

Data Inputs: $\quad$ Key bounding source term factors for safety analysis are: gross alpha, gross gamma, decay heat load, and isotopic concentrations $\left({ }^{137} \mathrm{Cs},{ }^{60} \mathrm{Co},{ }^{154 / 155} \mathrm{Eu},{ }^{90} \mathrm{Sr}\right.$, key alpha emitters of $\mathrm{U}, \mathrm{Pu}, \mathrm{Am}$ isotopes).

Justification: $\quad$ DOE must be assured that feed and product specifications are sufficient and not excessive. If the specifications are not sufficient, modifications in the facility design may be required. Stability of canister contents and dimensional and thermal properties are addressed by the Privatization Contracts' specifications and are considered less important to this DQO relative to the key bounding source terms. The density of the glass will not vary significantly regardless of loading. These ILAW safety analysis requirements do not drive specific data requirements for this DQO other than the specific radionuclide isotopes identified above as data inputs. Other data inputs will be addressed as part of other DQOs.

Additional Non- None.

Contract Data

Requirements for this DQO:

\subsection{ILAW Performance Assessment}

The DOE requires that a PA be performed before establishing long-term disposal facilities. The PA applies only to radionuclides and does not include non-radionuclides. The following justifies the need for the PA:

- DOE Order 5820.2A requires, prior to disposal, an estimate of long-term human health and safety effects. 
- DOE Order 435.1 (pending) requires, prior to construction, an estimate of long-term human health and safety effects.

- PA information was a driver for the ILAW contract specifications and will be important during Phase I negotiations.

- PA information is an input for disposal facility design.

A PA was completed for the ILAW waste form (Mann 1998) and submitted for review/approval in satisfaction of TPA milestone 90-05T. Periodic updates of this PA are planned at a frequency of at least once every 5 years. Three exposure scenarios, including exposure to inadvertent intruder, contamination of groundwater, and contamination of the atmosphere, have been evaluated. The following questions and time frames have been addressed in the PA for each scenario.

Question 9a: Intruder scenario-What is the maximum concentration of $\mathrm{X}$ analytes that will provide reasonable expectation that the one-time dose is less than $100 \mathrm{mrem} / \mathrm{yr}$ and the continuous dose is less than $500 \mathrm{mrem} / \mathrm{yr}$ ? The time of compliance is 500 to $10,000 \mathrm{yr}$ after closure of the disposal facility.

Question 9b: Groundwater scenario- What is the maximum amount of X analytes that provide reasonable expectation that the dose from contaminated groundwater will be less than $25 \mathrm{mrem} / \mathrm{yr}$ per DOE/NRC or less than $15 \mathrm{mrem} / \mathrm{yr}$ per US Environmental Protection Agency (EPA) from all uses of the water and the concentration in drinking water will be less than the value stated in the "National Primary Drinking Water Regulations" (10 CFR 141)? The time of compliance is 100 to 10,000 yr after closure of the disposal facility.

Question 9c: Atmospheric scenario-What is the maximum amount of $X$ analytes that provide reasonable expectation that the dose rate at the surface of the disposal facility will be less than $10 \mathrm{mrem} / \mathrm{yr}$ ? The time of compliance is 100 to 10,000 yr after closure of the disposal facility.

Data inputs and justification for each of the scenarios are presented below. The technical basis is further described by Mann (1998).

\section{Resident Farmer Intruder scenario}

In the PA, only ${ }^{126} \mathrm{Sn},{ }^{239} \mathrm{Pu}$, and ${ }^{241} \mathrm{Am}$ had sufficient inventory in the SSTs and DSTs after processing to present a concern to the intruder at $500 \mathrm{yr}$. This is based on the assumptions used in the PA (Mann 1998). One major factor is the amount of each radionuclide remaining in the liquid phase before mobilization. A second factor is the long half-life and a third is the fraction of analyte retained in the ILAW. For example, $100 \%$ of ${ }^{126} \mathrm{Sn}$ and $8 \%$ of ${ }^{241} \mathrm{Am}$ are assumed to remain in the liquid phase after pretreatment. If the fraction of analyte in the liquid phase is shown through characterization data to be lower than assumed, it is possible that facility design constraints can be released. 


\section{Groundwater scenario}

In the PA, only ${ }^{99} \mathrm{Tc},{ }^{79} \mathrm{Se},{ }^{231} \mathrm{~Pa}$, and ${ }^{233 / 234 / 235 / 238} \mathrm{U}$ had sufficient inventory in the SSTs and DSTs after processing to present a concern for the use of groundwater for times up to $10,000 \mathrm{yr}$. This is based on the assumptions used in the PA (Mann 1998). One major factor is the amount of each radionuclide remaining in the liquid phase before immobilization. A second factor is the long half-life, the third is the solubility of the analyte in the liquid, and the fourth is the mobility to groundwater. In the PA, $82 \%$ of ${ }^{99} \mathrm{Tc}$, and all ${ }^{79} \mathrm{Se}$ and ${ }^{231} \mathrm{~Pa}$ are assumed to remain in the liquid. Only $6 \%$ of the uranium isotopes were assumed to remain in the liquid. If these percentages decrease when actual data are obtained during production, it is possible that product performance/disposal system requirements could be relaxed.

\section{Atmospheric scenario}

None of the radionuclide concentrations forecasted to be present in the ILAW could produce a $10 \mathrm{mrem} / \mathrm{yr}$ exposure. The worst-case radionuclide would contribute approximately $10^{-8} \mathrm{mrem} / \mathrm{yr}$. There are no additional data needs for evaluation of the atmospheric scenario.

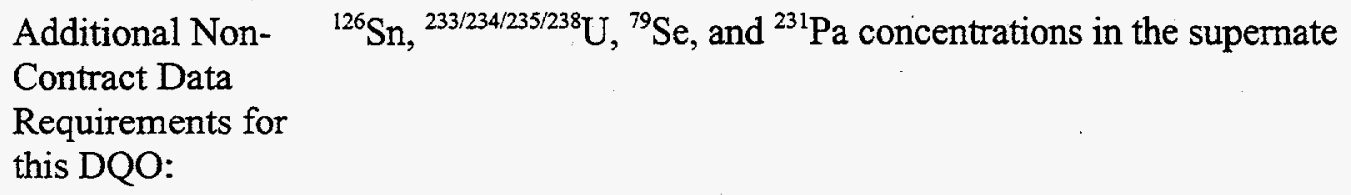

\subsection{NRC Guidelines for Incidental Waste}

The NRC concurred with the evaluation that the ILAW is incidental waste (i.e., not HLW). The NRC prepared a report of the review of the Technical Basis for Classification of Low-Activity Waste Fraction from Hanford Site Tanks (Petersen 1996). The review indicated that as long as the Technical Basis continued to be substantiated by the data gathered to support the ILAW and subsequent revisions of the PA supported the same conclusions presented to the NRC, the waste would be considered incidental (Paperiello 1997).

Question 10: Will the ILAW meet the following NRC guidelines for incidental waste?

- Waste has been processed to remove key radionuclides to the maximum extent that is technically and economically practical.

- Waste will be incorporated in a solid physical form at a concentration that does not exceed the applicable concentration limits for Class $\mathrm{C}$ low-level waste as set out in 10 CFR 61.

- Waste will be managed, pursuant to the Atomic Energy Act, so that safety requirements comparable to the performance objectives set out in 10 CFR 61 are satisfied. 


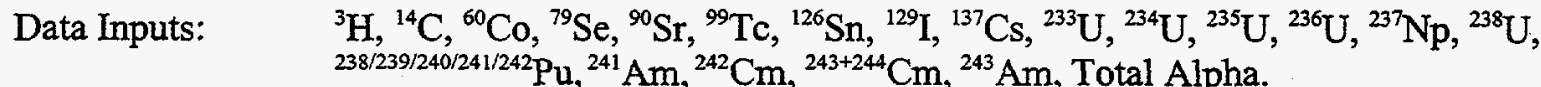

Justification: $\quad$ These radionuclides represent $99.9 \%$ of the inventory based on those specified in 10 CFR 61 or potentially detract from disposal system performance.

Additional Non- $\quad{ }^{3} \mathrm{H},{ }^{14} \mathrm{C},{ }^{79} \mathrm{Se},{ }^{126} \mathrm{Sn},{ }^{129} \mathrm{I},{ }^{233} \mathrm{U},{ }^{234} \mathrm{U},{ }^{235} \mathrm{U},{ }^{236} \mathrm{U},{ }^{238} \mathrm{U}$ concentrations and Total Contract Data Alpha in the supernate.

Requirements for this DQO:

\subsection{Summary of LAW Feed Data Inputs}

The LAW feed data inputs are presented in two functional groups:

Group 1: chemical analytes, radionuclides, physical properties, and conditions that are stated in the Privatization Contract LAW feed specification (Table 3.1).

Group 2: chemical analytes and radionuclides not included in specification; however, applicable to the objectives of this DQO (Tables 3.4 and 3.5).

\subsection{DQO Decision Logic Implementation}

Implementation of the overall DQO logic results in a decision as to what additional sampling and analysis are required to support completion of tank characterization to meet the requirements of this DQO related to: LAW feed staging, planning for treatment and storage facility design, PA, and NRC incidental waste guidelines. The logic limits sampling and analysis to static waste for which existing information is incomplete. For most tank wastes, static implies that no additional transfers will occur until the waste is mobilized and retrieved for transfer to the intermediate feed staging tanks. Some wastes classified as static may undergo a limited amount of chemical adjustments (i.e., caustic addition) or blending with other static or well characterized waste streams. Completeness of the data is judged through comparison of the analytes measured with the analytes requested in Groups 1 and 2.

The decision logic defining sampling and analysis requirements in support of the TWRS LAW privatization project is shown as a logic flow diagram in Figure 3.3. For purposes of discussion, each diagram element has been numbered relative to each applicable decision sequence shown. The cited input sources may be replaced with equivalent documentation at a future date. The references apply to the most recent revision at the time this DQO was issued. Additional sources may be sought if the referenced documents are not updated. Data collected before May 1989 is not applicable to this DQO.

Gate 1: Are any major waste transfers planned between the scheduled sampling date and the scheduled date for staging the feed [GATE 1]?

The TWRS Operational and Utilization Plan (Kirkbride et al. 1997) calls for transfer of waste from a source tank to an intermediate DST that will be used by the PHMC contractor as a feed staging location. 
Because transfer of wastes within the tank farm may significantly impact the composition of the source tank waste, highest priority for sampling and characterization will be given to those tank wastes for which no significant transfers are planned up to the scheduled transfer to the intermediate feed staging tank.

Two input sources [1-1] will be used to determine [1-2] the transfer activity for a given tank waste relative to the planned dates and final transfer to the intermediate feed staging tank:

- The next revision of the TWRS Operational and Utilization Plan (Kirkbride et al. 1997) will provide the scheduled date for transfers to the intermediate feed staging tank.

- Operational Waste Volume Projection (Koreski 1997) identifies the planned waste transfers, from which a determination of dates of future transfers may be identified.

If a significant quantity of waste will not be transferred to the source tank before feed staging, the tank waste is a candidate for sampling and characterization (continue to Gate 2). Conversely, if a significant number of transfers or transfer of a large quantity of waste is planned, sample collection for privatization is given a low priority [1-3] [continue to Endfunction C].

Gate 2: Have any major tank waste transfers occurred between the last sampling date and the current date [GATE 2]?

The representativeness of existing characterization information relative to the current tank contents will depend, in part, on the number, quantity, and type of waste transfers that have occurred since the last sampling event.

Input sources [2-1] to be used to determine [2-2] the historical transfer activity for a given tank waste relative to the most recent sampling event:

- Baseline Sampling Schedule (Stanton 1997) ${ }^{1}$ is updated, as needed, to reflect the most current sampling schedule and will be used to identify previous sampling events and planned future sample dates.

- The Hanford Defined Waste (HDW) document (Agnew 1997, previously known as the Historical Tank Content Estimate [HTCE]), which describes transfers through December 31, 1993.

- Waste Tank Summary Reports (e.g., Hanlon 1998) will provide a complimentary source of recent waste transfer information.

- Tank characterization reports (TCR).

If, since the most recent sampling event a significant number of transfers or transfer of a large quantity of waste has occurred, or a dissimilar waste type has been transferred to the source tank, the tank waste is a candidate for sampling and characterization [2-3] (continue to Endfunction A).

\footnotetext{
'Stanton, GA. 1997. Baseline Sampling Schedule. Change 09-0X (internal memorandum). Lockheed Martin Hanford Company, Richland, Washington.
} 
If, since the most recent sampling event, significant waste transfers have not been associated with the source tank, further consideration is required to determine whether additional sampling and characterization are required (continue to Gate 3).

NOTE: Chemical reactions occurring with time may also alter the waste composition and properties. Although there is insufficient scientific information to predict the extent of change due to aging, consideration may also be given as to the representativeness of the data relative to the period of time elapsed since the last sampling event.

Gate 3: Does characterization information exist to compare with the LAW feed envelope contract specification and to support process development, treatment and storage/disposal facility's design, PA, NRC incidental waste guidelines, and environmental planning [GATE 3]?

The determination of "adequate and applicable" information will be made in two steps. Decision Gate 3 addresses adequate, where adequate is defined as the availability of information relative to data needs lists of analytes. Decision Gates 4 and 5 address the second step, which requires an assessment of the data applicability based on given criteria.

The first step requires collection of the analytical data from which the reported analytes and physical properties will be identified. The tank characterization reports will be used as primary input sources from which the list of reported analytes and physical properties will be derived [3-1]. When available, technical reports, Tank Waste Information Network System (TWINS) database (solids and liquids), and the standard inventory (Kupfer 1997) may be used as supporting input sources.

Three lists of reported constituents and physical properties will be prepared. One list will contain chemical analytes, radionuclides and physical properties given in the LAW feed contract specification (refer to Tables 3.2 and 3.3). This list will be referred to as "Group 1-reported." The second list will contain those chemical analytes, radionuclides and physical properties believed also to be relevant to other data needs addressed in this DQO; however, these are not listed in the contract envelope specification (refer to Tables 3.4 and 3.5). This list will be referred to as "Group 2-reported." Group 2 analytes were not assigned contract specification limits because of the lack of available characterization information. Both lists are considered of equal priority for characterization during this planning phase. The reported constituents and properties will be compared with Groups 1 and 2 lists [3-2].

If the list of reported analytes and physical properties is incomplete when compared with Tables 3.2 through 3.5, then the tank waste is to be sampled and characterized for the missing analytes [3-3] (continue to Endfunction A). If the list of reported analytes and physical properties is complete when compared to Tables 3.2 through 3.5, further assessment of the characterization information is required (continue to Gates 4 and 5).

\section{Gate 4: Are the historical Group 1 analyte and physical property data applicable [GATE 4]?}

The historical analyte and physical property data relative to Group 1 (see Tables 3.2 and 3.3) will be compiled [4-2] from the input sources [4-1] and compared with Group 1 assessment criteria [4-3]. The assessment criteria for Group 1 require that the collection and analysis strategy for any one analyte be consistent with or equivalent to the optimization guidelines provided in Section 7.0. Sample collection and 
characterization for Group 1 analytes are triggered when the data set does not meet the assessment criteria [4-4] (continue to Endfunction A).

If characterization information meets the criteria set forth in this DQO process, sampling specifically for TWRS Privatization LAW Group 1 analytes is not required [4-5]. However, if sample collection and multi-analyte techniques are required for some Group 1 analytes/properties and/or are called for in support of other DQOs, all analytes/properties measured via these multi-analyte techniques (i.e., fortuitous analyses) are to be reported in support of TWRS Privatization (continue to Endfunction B).

\section{Gate 5: Does the Group 2 analyte and physical property information meet assessment criteria} [GATE 5]?

The historical analyte and physical property data relative to Group 2 (see Tables 3.4 and 3.5 ) will be compiled [5-2] from the input sources [5-1] and compared with Group 2 assessment criteria [5-3]. When available, technical reports, TWINS database (solids and liquids), and the standard inventory (Kupfer 1997) that contain waste characterization information may be used as supporting input sources.

The assessment criteria for Group 2 require that the collection and analyses strategy for any one analyte be consistent with or equivalent to the optimization guidelines provided in Section 7.0.

Sample collection and characterization for Group 2 analytes is triggered when the data set does not meet the assessment criteria [5-4] (continue to Endfunction A).

If characterization information meets the criteria set forth in this DQO process, sample collection specifically for TWRS Privatization Group 2 analytes and properties is not required [5-5]. However, if sample collection and multi-analyte techniques are required for some Group 2 analytes/properties and/or called for in support of other DQOs, all analytes/properties measured via these multi-analyte techniques (i.e., fortuitous analyses) are to be reported in support of TWRS Privatization (continue to Endfunction B). 


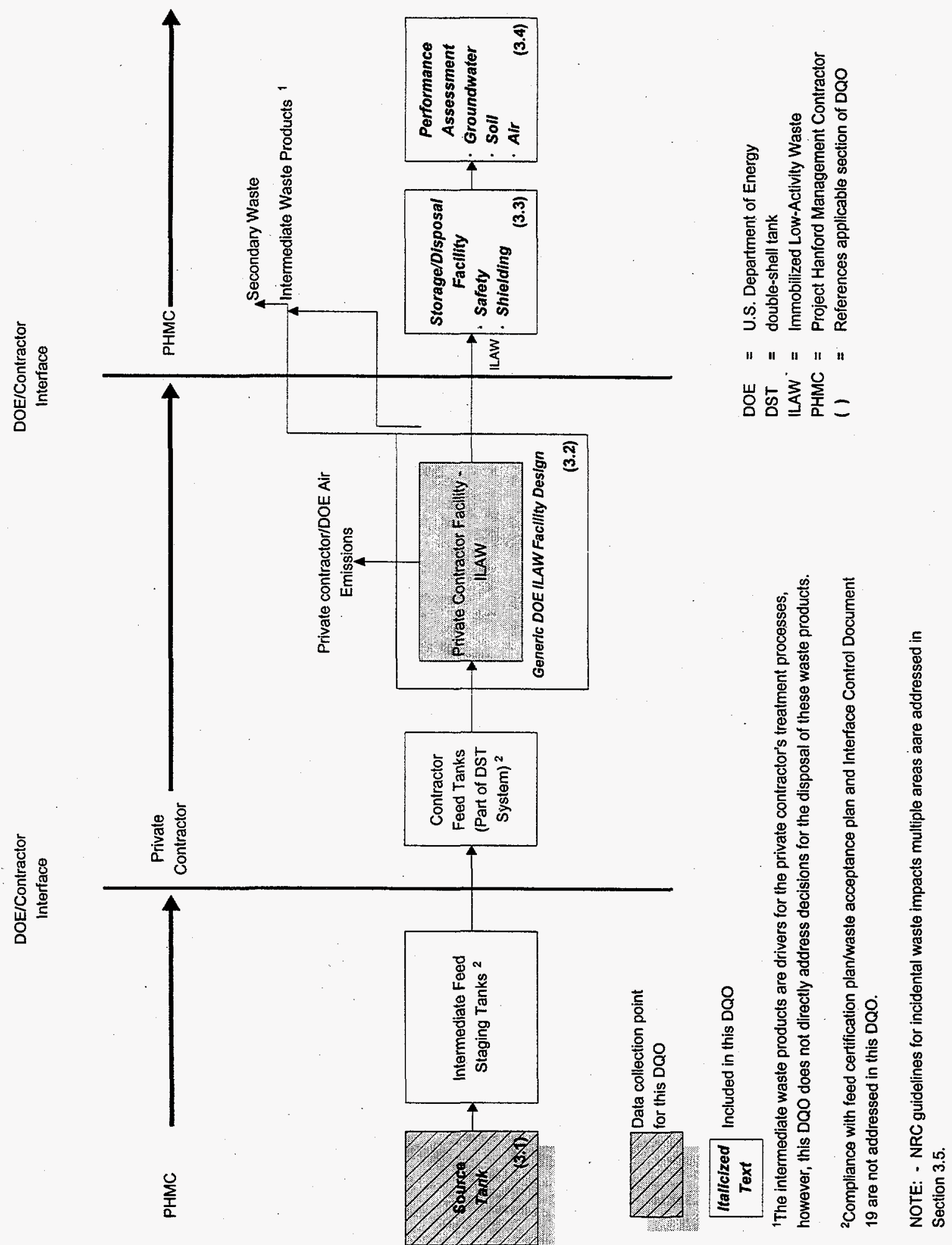

Figure 3.1. DQO Interfaces for ILAW Phase I Flowsheet 


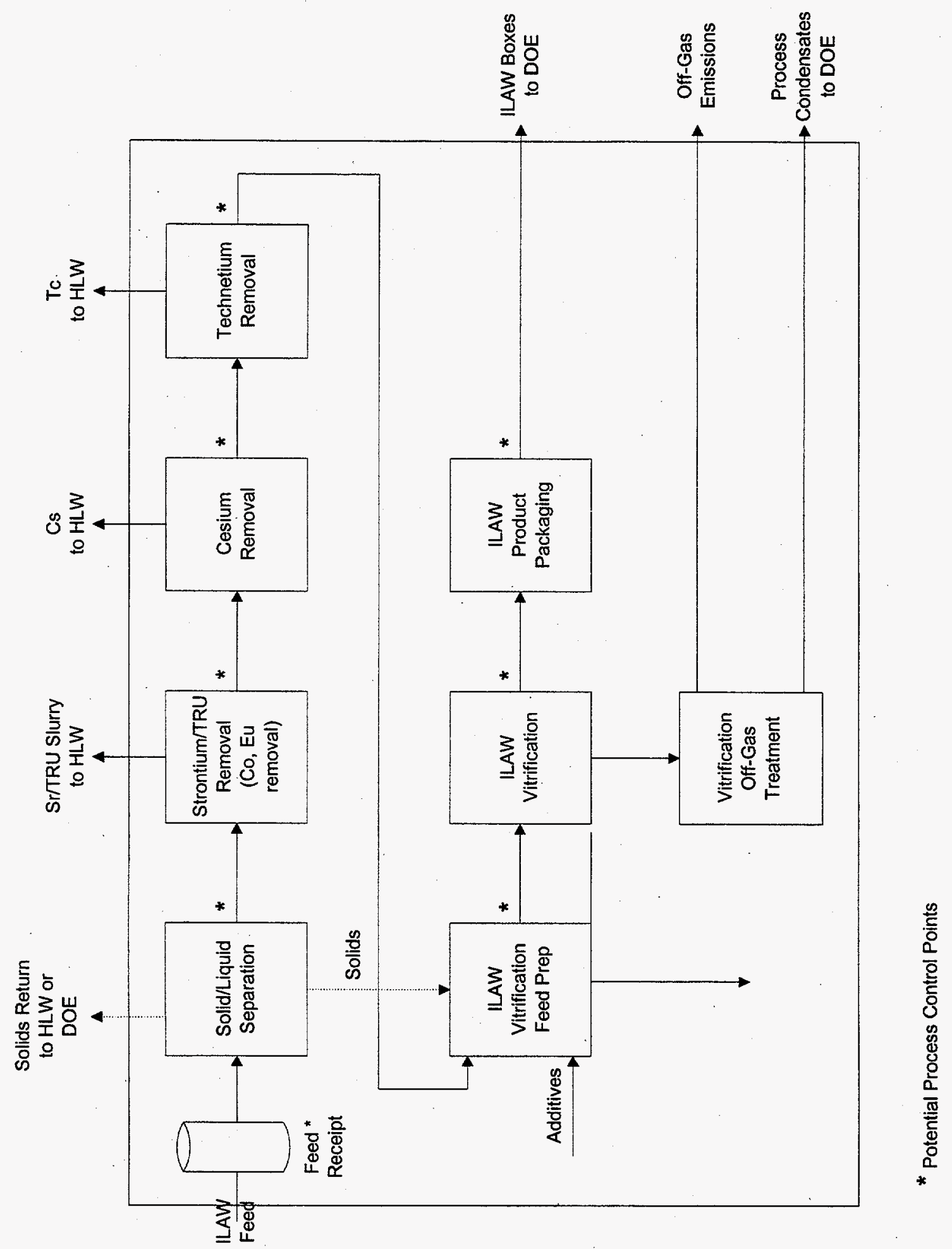

Figure 3.2. Generic Process Flowsheet for Private Contractor LAW Service 


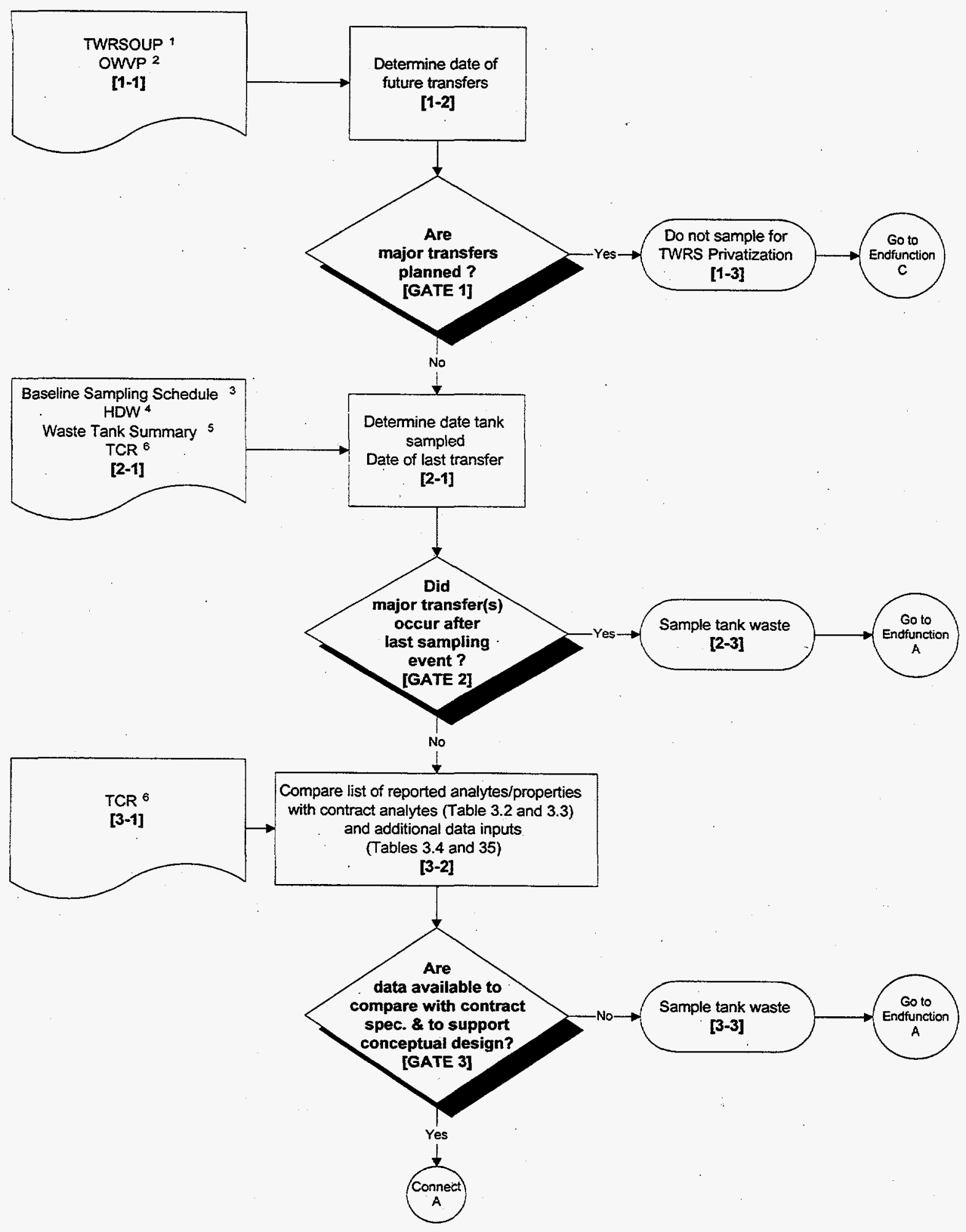

Figure 3.3. TWRS Privatization LAW DQO Decision Logic (Page 1 of 3) 


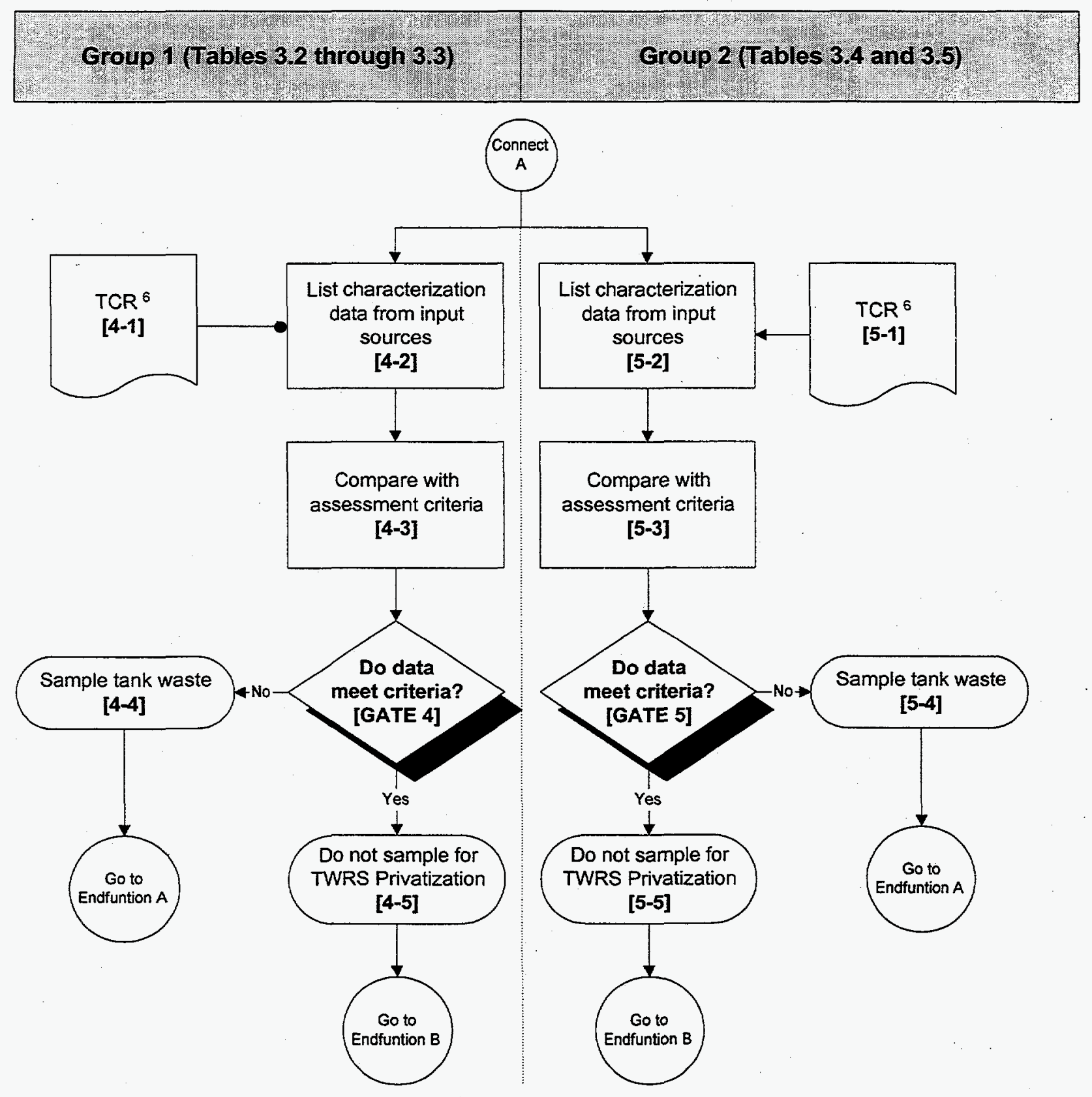

Figure 3.3. TWRS Privatization LAW DQO Decision Logic (Page 2 of 3) 


\section{ENDFUNCTION A}

Collect sample and conduct analyses in compliance with Section 7.0 (continue to Endfunction B).

\section{ENDFUNCTION B}

If no sample is currently archived for TWRS Privatization process testing, collect and archive sample. This sample will be used for process testing to support LAW feed staging activities (continue to Endfunction C).

\section{ENDFUNCTION C}

If sample collection and multi-analyte techniques are required to support other DQOs, all analytes/properties measured via these techniques are to be reported in support of TWRS Privatization.

Notes:

${ }^{1}$ Kirkbride et al. (1997)

${ }^{2}$ Operational Waste Volume Projection (Koreski 1997)

${ }^{3}$ Stanton (1997)

${ }^{4}$ Agnew (1997)

${ }^{5}$ Hanlon (1998)

${ }^{6}$ Individual tank characterization reports. When available, technical reports, TWINS database (solids and liquids), and the standard inventory (Kupfer 1997) may be used as supporting input sources.

Figure 3.3. TWRS Privatization LAW DQO Decision Logic (Page 3 of 3) 
Table 3.1. Group 1 List and Corresponding Contract LAW Feed Specification Envelope Limits (DOE-RL 1998b).

\begin{tabular}{|c|c|c|c|}
\hline 4rinater. & 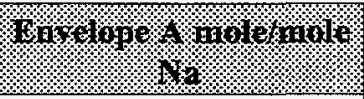 & 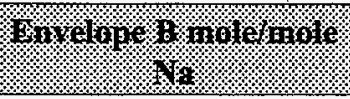 & 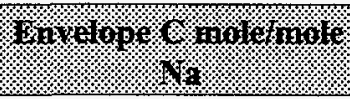 \\
\hline $\mathrm{Al}$ & $2.5 \mathrm{E}-01$ & $2.5 \mathrm{E}-01$ & $2.5 \mathrm{E}-01$ \\
\hline $\mathrm{Ba}$ & $1.0 \mathrm{E}-04$ & $1.0 \mathrm{E}-04$ & 1.0 E-04 \\
\hline $\mathrm{Ca}$ & $4.0 \mathrm{E}-02$ & $4.0 \mathrm{E}-02$ & $4.0 \mathrm{E}-02$ \\
\hline $\mathrm{Cd}$ & $4.0 \mathrm{E}-03$ & $4.0 \mathrm{E}-03$ & 4.0 E-03 \\
\hline $\mathrm{Cl}$ & $3.7 \mathrm{E}-02$ & $8.9 \mathrm{E}-02$ & 3.7 E-02 \\
\hline $\mathrm{Cr}$ & $6.9 \mathrm{E}-03$ & $2.0 \mathrm{E}-02$ & $6.9 \mathrm{E}-03$ \\
\hline $\mathrm{F}$ & $9.1 \mathrm{E}-02$ & $2.0 \mathrm{E}-01$ & $9.1 \mathrm{E}-02$ \\
\hline $\mathrm{Fe}$ & $1.0 \mathrm{E}-02$ & $1.0 \mathrm{E}-02$ & $1.0 \mathrm{E}-02$ \\
\hline $\mathrm{Hg}$ & $1.4 \mathrm{E}-05$ & $1.4 \mathrm{E}-05$ & $1.4 \mathrm{E}-05$ \\
\hline $\mathrm{K}$ & $1.8 \mathrm{E}-01$ & $1.8 \mathrm{E}-01$ & $1.8 \mathrm{E}-01$ \\
\hline $\mathrm{La}$ & $8.3 \mathrm{E}-05$ & $8.3 \mathrm{E}-05$ & $8.3 \mathrm{E}-05$ \\
\hline $\mathrm{Na}$ & $1.0 \mathrm{E}-00$ & $1.0 \mathrm{E}-00$ & $1.0 \mathrm{E}-00$ \\
\hline $\mathrm{Ni}$ & $3.0 \mathrm{E}-03$ & $3.0 \mathrm{E}-03$ & $3.0 \mathrm{E}-03$ \\
\hline $\mathrm{NO}_{2}^{-}$ & $3.8 \mathrm{E}-01$ & $3.8 \mathrm{E}-01$ & $3.8 \mathrm{E}-01$ \\
\hline $\mathrm{NO}_{3}^{-}$ & $8.0 \mathrm{E}-01$ & $8.0 \mathrm{E}-01$ & $8.0 \mathrm{E}-01$ \\
\hline $\mathrm{Pb}$ & $6.8 \mathrm{E}-04$ & $6.8 \mathrm{E}-04$ & $6.8 \mathrm{E}-04$ \\
\hline $\mathrm{PO}_{4}^{-3}$ & $3.8 \mathrm{E}-02$ & $1.3 \mathrm{E}-01$ & $3.8 \mathrm{E}-02$ \\
\hline $\mathrm{SO}_{4}^{-2}$ & $1.0 \mathrm{E}-02$ & $7.0 \mathrm{E}-02$ & $2.0 \mathrm{E}-02$ \\
\hline TIC & $3.0 \mathrm{E}-01$ & $3.0 \mathrm{E}-01$ & $3.0 \mathrm{E}-01$ \\
\hline TOC & $5.0 \mathrm{E}-01$ & $5.0 \mathrm{E}-01$ & $5.0 \mathrm{E}-01$ \\
\hline $\mathrm{U}$ & $1.2 \mathrm{E}-03$ & $1.2 \mathrm{E}-03$ & $1.2 \mathrm{E}-03$ \\
\hline
\end{tabular}

\begin{tabular}{|c|c|c|c|}
\hline Analyte & Bg/mole Na & Bg/mole Na & Bg/mole Na \\
\hline TRU $^{1}$ & $4.8 \mathrm{E}+05$ & $4.80 \mathrm{E}+05$ & $3.0 \mathrm{E}+06$ \\
\hline${ }^{137} \mathrm{Cs}$ & $4.3 \mathrm{E}+09$ & $2.0 \mathrm{E}+10$ & $4.3 \mathrm{E}+09$ \\
\hline${ }^{90} \mathrm{Sr}$ & $4.4 \mathrm{E}+07$ & $4.4 \mathrm{E}+07$ & $8.0 \mathrm{E}+08$ \\
\hline${ }^{99} \mathrm{Tc}$ & $7.1 \mathrm{E}+06$ & $7.1 \mathrm{E}+06$ & $7.1 \mathrm{E}+06$ \\
\hline${ }^{60} \mathrm{Co}$ & $6.1 \mathrm{E}+04$ & $6.1 \mathrm{E}+04$ & $3.7 \mathrm{E}+05$ \\
\hline${ }^{154} \mathrm{Eu}$ plus ${ }^{155} \mathrm{Eu}$ & $1.2 \mathrm{E}+06$ & $1.2 \mathrm{E}+06$ & $4.3 \mathrm{E}+06$ \\
\hline
\end{tabular}

Notes:

${ }^{1}$ TRU is defined as alpha-emitting radionuclides with an atomic number greater than 92 . TRU content is to be determined by measurement of total alpha and ${ }^{237} \mathrm{~Np},{ }^{238} \mathrm{Pu},{ }^{239} \mathrm{Pu},{ }^{240} \mathrm{Pu},{ }^{241} \mathrm{Pu}$, ${ }^{242} \mathrm{Pu},{ }^{241} \mathrm{Am},{ }^{242} \mathrm{Cm}\left({ }^{242 \mathrm{~m}} \mathrm{Am},{ }^{242} \mathrm{Am}\right),{ }^{243+244} \mathrm{Cm}$ and ${ }^{243} \mathrm{Am}$.

The contract specification for LAW feed envelopes also defines the following requirements. The waste feed will be delivered with a $\mathrm{Na}$ concentration between $3 \mathrm{M}$ and $10 \mathrm{M}$. The insoluble solids fraction will not exceed $2 \mathrm{wt} \%$ of the waste transferred. Solids concentrations of $\mathrm{Al}, \mathrm{Cr}, \mathrm{P}, \mathrm{S}$, $\mathrm{Si}, \mathrm{Na}, \mathrm{TIC}, \mathrm{TOC},{ }^{90} \mathrm{Sr},{ }^{137} \mathrm{Cs},{ }^{60} \mathrm{Co},{ }^{154} \mathrm{Eu},{ }^{155} \mathrm{Eu}$, and total alpha are required. No visible separate organic phase will be present in the waste feed. Gas generation in the waste feed is expected. 


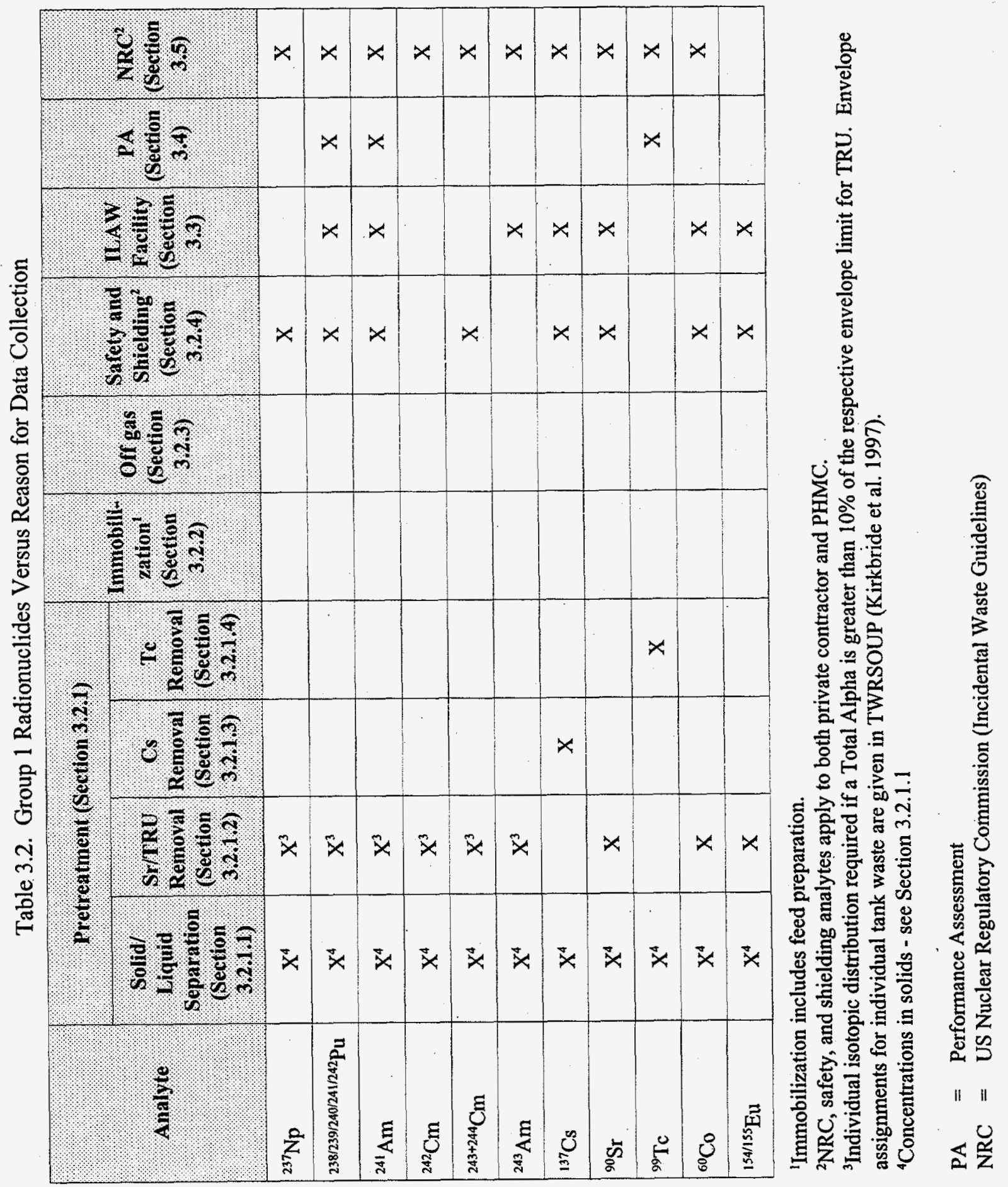


Table 3.3. Group 1 Chemical Analytes and Physical Properties Versus Reason for Data Collection ${ }^{1}$

\begin{tabular}{|c|c|c|c|c|c|c|}
\hline \multirow[b]{2}{*}{ Analyte } & \multicolumn{4}{|c|}{ Pretreatrinent (Section 3.2.1) } & \multirow[b]{2}{*}{ 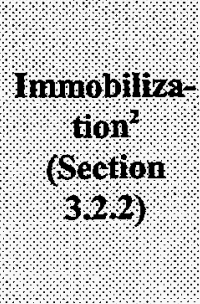 } & \multirow[b]{2}{*}{$\begin{array}{l}\text { Offgas } \\
\text { (Section } \\
3.2 .3)\end{array}$} \\
\hline & $\begin{array}{l}\text { sotid! } \\
\text { Siquird } \\
\text { Separation } \\
(\text { Section } \\
3.2 .1 .1)\end{array}$ & $\begin{array}{l}\text { SrITRU } \\
\text { Removal } \\
(\text { Section } \\
3.2,1.2)\end{array}$ & $\begin{array}{c}\text { Cs } \\
\text { Removal } \\
(\text { Section } \\
3.2 .1 .3)\end{array}$ & $\begin{array}{l}\text { Tc } \\
\text { Removal } \\
(\text { Section } \\
3.2 \% 4)\end{array}$ & & \\
\hline $\mathrm{Al}$ & $\mathrm{X}^{3}$ & & & & $\mathrm{X}$ & \\
\hline $\mathrm{Ba}$ & $\mathrm{X}^{3}$ & $X$ & & & $\mathrm{X}$ & \\
\hline $\mathrm{Ca}$ & $\mathrm{X}^{3}$ & $\mathrm{X}$ & & & & \\
\hline $\mathrm{Cd}$ & $\mathrm{X}^{3}$ & $\mathrm{X}$ & & & $\mathrm{X}$ & \\
\hline $\mathrm{Cl}$ & $\mathrm{X}^{3}$ & & & $X$ & $\mathrm{X}$ & $\mathrm{X}$ \\
\hline $\mathrm{Cr}$ & $\mathrm{X}^{3}$ & & & & $\mathrm{x}$ & \\
\hline $\mathrm{F}$ & $\mathrm{X}^{3}$ & & & $X$ & $\mathrm{X}$ & $X$ \\
\hline $\mathrm{Hg}$ & $\mathrm{X}^{3}$ & & & & $\mathrm{X}$ & \\
\hline $\mathrm{K}$ & $\mathrm{X}^{3}$ & & $\mathrm{X}$ & & $\mathrm{X}$ & \\
\hline $\mathrm{Na}$ & $\mathrm{X}^{3}$ & & $X$ & & $\mathrm{X}$ & \\
\hline $\mathrm{Ni}$ & $\mathrm{X}^{3}$ & $\mathrm{X}$ & & & & \\
\hline $\mathrm{NO}_{2}$ & $\mathrm{X}^{3}$ & & & $X$ & $\mathrm{X}$ & $\mathrm{X}$ \\
\hline $\mathrm{NO}_{3}$ & $\mathrm{X}^{3}$ & & & $X$ & $\mathrm{X}$ & $\mathrm{X}$ \\
\hline $\mathrm{Pb}$ & $\mathrm{X}^{3}$ & & & & $\mathrm{x}$ & \\
\hline $\mathrm{PO}_{4}$ & $\mathrm{X}^{3}$ & & . & $\mathrm{X}$ & & \\
\hline $\mathrm{SO}_{4}$ & $\mathrm{X}^{3}$ & & & $\mathrm{X}$ & & \\
\hline TIC & $\mathrm{X}^{3}$ & & & $\mathrm{X}$ & $\mathrm{X}$ & $X$ \\
\hline TOC & $\mathrm{X}^{3}$ & & $\mathrm{X}$ & $\mathrm{X}$ & $X$ & $\mathrm{X}$ \\
\hline $\mathbf{U}$ & $\mathrm{X}^{3}$ & & & & & \\
\hline
\end{tabular}

${ }^{1} \mathrm{NRC}$ incidental waste guidelines and shielding are not applicable to nonradionuclides.

${ }^{2}$ Immobilization includes feed preparation.

${ }^{3}$ Concentrations in solids - see Section 3.2.1.1

$\mathrm{TIC}=$ total inorganic carbon

$\mathrm{TOC}=$ total organic carbon 


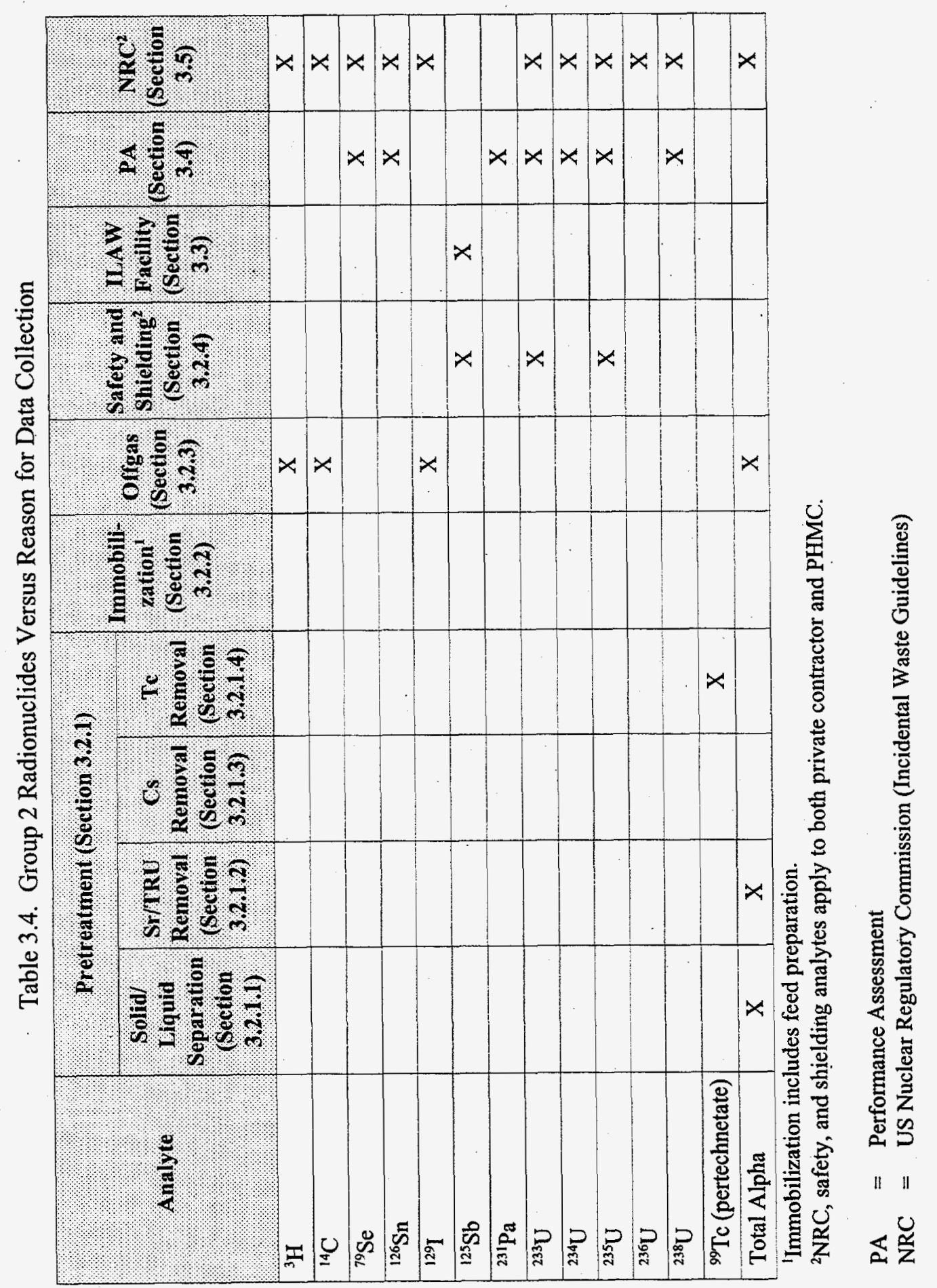


Table 3.5. Group 2 Chemical Analytes and Physical Properties Versus Reason for Data Collection ${ }^{1}$

\begin{tabular}{|c|c|c|c|c|c|c|}
\hline \multirow[b]{2}{*}{ Aralyte } & \multicolumn{4}{|c|}{ Pretreatment (Section 32,1 ) } & \multirow[b]{2}{*}{$\begin{array}{l}\text { Immobiliza } \\
\text { (Section' } \\
(3.2 .2)\end{array}$} & \multirow[b]{2}{*}{$\begin{array}{l}\text { Offgas } \\
\text { (Section } \\
3.3)\end{array}$} \\
\hline & $\begin{array}{l}\text { Solidil } \\
\text { Separation } \\
(\text { Section } \\
3.2,1)\end{array}$ & $\begin{array}{l}\text { SrITRU } \\
\text { Removal } \\
(\text { Section } \\
3.2,1,2)\end{array}$ & $\begin{array}{l}\text { cs } \\
\text { Removal } \\
(\text { Section } \\
3.2 .13)\end{array}$ & $\begin{array}{l}\text { To } \\
\text { Removal } \\
(\text { Section } \\
3.2 .1 .4)\end{array}$ & & \\
\hline $\mathrm{Ag}$ & $\mathrm{X}^{4}$ & & & & $\mathrm{X}$ & \\
\hline As & & & & & $\mathrm{X}$ & \\
\hline $\mathrm{Bi}$ & $X^{4}$ & & & & & \\
\hline Co & & $\mathrm{X}$ & & & & \\
\hline Cs (total) & & & $\mathrm{X}$ & & & \\
\hline $\mathrm{Eu}$ & & $X$ & & & & \\
\hline $\mathrm{Mg}$ & $\mathrm{X}^{4}$ & & & & & \\
\hline $\mathrm{Mn}$ & & $\mathrm{X}$ & & & & \\
\hline $\mathrm{NH}_{4} / \mathrm{NH}_{3}$ & & & & & & $\mathrm{X}$ \\
\hline $\mathrm{OH}$ & $\mathrm{X}^{4}$ & & $\mathrm{X}$ & $\mathrm{X}$ & & \\
\hline$P$ & $\mathrm{X}^{4}$ & & & & $\mathrm{X}$ & \\
\hline $\mathrm{Pd}$ & $\mathrm{X}^{4}$ & & & & & \\
\hline $\mathrm{Rh}$ & $\mathrm{X}^{4}$ & & & & & \\
\hline $\mathrm{Ru}$ & $\mathrm{X}^{4}$ & & & & & \\
\hline$S$ & $\mathrm{X}^{4}$ & & & & $X$ & $\mathrm{X}$ \\
\hline $\mathrm{Se}$ & & & & & $\mathrm{X}$ & \\
\hline $\mathrm{Si}$ & $\mathrm{X}^{4}$ & & & & $\mathrm{X}$ & \\
\hline Sr (total) & & $\mathrm{X}$ & & & & \\
\hline $\mathrm{Ti}$ & $\mathrm{X}^{4}$ & & & & & \\
\hline $\mathrm{Zr}$ & $\mathrm{X}^{4}$ & & & & & \\
\hline
\end{tabular}

Wt\% Solids

\section{$\mathrm{X}$}

'NRC incidental waste guidelines and shielding are not applicable to nonradionuclides.

${ }^{2}$ Immobilization includes feed preparation.

${ }^{3}$ Wet and dry basis. Refer to Section 7.0.

${ }^{4}$ Concentration in solids - see Section 3.2.1.1 


\subsection{Boundaries}

This DQO process addresses the characterization of waste that could potentially be used to meet the TWRS Privatization Phase I LAW feed requirements. The waste in the boundary of this DQO is the material in the source tank (refer to Figure 1.1). The waste includes both the supernate and solids which may be mobilized and retrieved from the source tank to the intermediate feed staging tanks. Complete characterization of the source tanks are not within the scope of this DQO and requires data input as delineated in other applicable DQOs. For instance, data required to characterize source tank waste with respect to RCRA requirements and corresponding state requirements is addressed in a separate Regulatory DQO (Wiemers et al. 1998).

A description of the candidate waste feed selection process is updated and published each year in the TWRSOUP (Kirkbride et al. 1997) unless circumstances dictate a change in the schedule for updating the document. The characterization requirements outlined in this DQO document apply to waste samples from the candidate Phase I LAW source tanks. The candidate source tanks and the envelope specifications to which they apply are:

$$
\begin{array}{ll}
\text { Envelope A: } & \text { AN103, AN104, AN105, AW101 } \\
\text { Envelope B: } & \text { AZ101, AZ102 } \\
\text { Envelope C: } & \text { AN102, AN107, SY101 }
\end{array}
$$

To help quantify spatial uncertainty, each tank waste will be modeled as though it were composed of strata, including floating crust, supernate, saturated supernate or slurry and solids. The initial strata assignments will be based on historical records, such as core sample analysis and fill history. Selected analytes will be used to determine the extent of stratification. When stratification is not observed, composites of the strata may be used for a more comprehensive characterization. The evaluation by substrata is needed because materials may be transferred from the source tank in separate fractions to the intermediate feed staging tank.

This DQO process does not address verification of the intermediate feed staging tank contents, or quantification of the materials in the private contractor's feed tank, downstream processes, or products. This DQO does not address sampling and characterization for permitting or environmental compliance. These activities will be managed through DOE's contracting processes and other DQOs. 


\subsection{Decision Rules}

Decision rules define how to evaluate results and actions required as a result of exceeding or not exceeding an action level. The contract (DOE-RL 1998b) envelope limits may be considered as "target" action limits and should not be used in the same context in which action limits are typically defined for regulatory or safety applications. The contract envelope specifications represent a contractual agreement that may be negotiated during the early planning stages, with minimal impact to the DOE, the site contractor and the private contractor. Implementation of this DQO process early in the planning stages of TWRS Privatization allows for implementation of many alternatives to mitigate an incorrect decision. As the date for transfer of waste from the source tank to the intermediate staging tank approaches, staging sequence and facility designs become final, options for mitigation will decrease and the negative consequences of a wrong decision will increase; however, the consequences are unlikely to become catastrophic.

The specifications provide the only action limits until the processes are finalized in the contracts. While multiple questions/decisions are presented in Section 3.0, these can be summarized in two general questions with associated decision rules.

- What waste should be staged for the LAW treatment facility?

- What information may influence process technologies used in the LAW facility?

General decision rules for staging are:

1. If waste meets the contracts' envelope specifications, the waste can be considered as a candidate for LAW feed staging.

2. If waste exceeds the envelope limits, technical staff will assess alternatives to meeting contract order quantities as described in the Privatization Contract clause H.43.

This DQO defines data requirements that will be used by DOE in managing the private contractor and PHMC contracts. Data gathered as a result of this DQO will also provide the private contractor with additional information for planning treatment processes and facility design. The private contractor must design processes and build/operate treatment facilities. Decision rules for planning process technologies and plant design are either not in final contracts at this time or are procurement sensitive and, therefore, are not incorporated in this revision of the DQO process documentation.

Decision rules associated with final verification of the waste feed composition and subsequent downstream validation points will be the responsibility of the integrated process/product teams, will be developed during Phase IB, and/or will require additional sampling and characterization after final staging.

It is anticipated that the TWRSOUP (Kirkbride et al. 1997) will be updated and this DQO process revisited as new process information is received and as private contractor technologies and integrated process/product team needs are better defined. 


\subsection{Decision Error Assessment}

The characterization data collected through implementation of this DQO will be used by a variety of customers; therefore, it is difficult to initially specify acceptable limits of uncertainty or decision error. The purpose of this section is to assess the errors resulting in the worst consequence and determine the allowable error rate, that is, select the appropriate values for statistical parameters used in analyzing the data. These parameters are listed in Section 6.2. The result of this assessment is a recommendation as to the number of samples and the sampling design outlined in Section 7.0.

Because the analysis procedures for this DQO require compositing of liquid and solids fractions from the individual samples, there are two primary sampling decisions: (1) the number and location of individual samples and (2) the number of subsamples for analysis of the composites. In summary, the analyses presented in this Section support the tank sampling procedures illustrated in Figure 7.2 and described in Section 7.2. This Section also pertains to the required composite subsampling procedures in Section 7.5 and the reanalysis procedures associated with data precision requirements described in Section 7.6.1.

\subsection{Consequences of an Incorrect Decision}

To assess the limits of decision error, one must first examine the consequences of making an incorrect decision. In this case, two incorrect decisions could be made with the following results.

- Waste could be deemed to be within the envelope when it actually is not.

Result: After movement to the DOE intermediate feed staging tank, planned additional characterization would be performed and the waste concentrations may be corrected. The waste may still be suitable as LAW feed as described in the Privatization Contract clause H.43. In this case, no negative result would occur except loss of time and efficiency.

"In the event that DOE identifies feed that is out of specification, the Contractor shall determine its treatability within the Contractors facility. The treatability determination shall be based solely upon the technical ability to process the waste, the facility permits and the facility safety authorization basis. If the waste is treatable within the facility, a price for processing the out of specification feed will be negotiated based upon the incremental impacts to Contractor costs and facility processing rates. The Contractor shall provide a cost proposal to support the price impacts for processing the out-of-specification waste (DOE 1998)."

If, during movement to the DOE intermediate feed staging tank the error was not found, the private contractor may receive material that could not be processed. Because the DOE intermediate feed staging tank acts as a backup for envelope compatibility assessment, this is an unlikely event. However, the consequences of this type of error are very significant. Transfer of LAW feed to the private contractor will be determined by ICD-19 and the feed certification strategy described therein. 
- Waste could be deemed to exceed the envelope criteria when actually the waste is within the envelope criteria.

Result: If the waste was deemed to be out of specification, the procedure described in the Privatization Contract clause H.43 would be implemented. In this case no negative result would occur except loss of time and efficiency.

"In the event that DOE identifies feed that is out of specification, the Contractor shall determine its treatability within the Contractors facility. The treatability determination shall be based solely upon the technical ability to process the waste, the facility permits and the facility safety authorization basis. If the waste is treatable within the facility, a price for processing the out of specification feed will be negotiated based upon the incremental impacts to Contractor costs and facility processing rates. The Contractor shall provide a cost proposal to support the price impacts for processing the out-of-specification waste (DOE 1998)."

After movement to the DOE intermediate feed staging tank, planned additional characterization would be performed and the waste concentrations may be corrected. In this case, the impact of the error would be minimal.

Implementation of this DQO process early in the planning stages of TWRS Privatization Project allows for implementation of many alternatives to mitigate an incorrect decision. As the date for transfer of waste from the source tank to the DOE intermediate feed staging tank approaches, options for mitigation of incorrect selection of waste will decrease and the negative consequences of a wrong decision will increase. Consequences of an incorrect decision are unlikely to be catastrophic because alternatives such as these described in the Privatization Contract clause $\mathrm{H} .43$ can be implemented.

\subsection{Decision Error}

Decision uncertainty is a function of the following parameters:

- number of samples

- level of false positives, Type I error with probability $\alpha$

- level of false negatives, Type II error with probability $\beta$

- action level or envelope criteria

- variability (standard deviation or relative standard deviation [RSD]).

In hypothesis testing, both a null hypothesis $\left(\mathrm{H}_{0}\right)$ and an alternate hypothesis $\left(\mathrm{H}_{2}\right)$ are stated. Data gathered from a sampling event are used to evaluate the hypothesis, and decisions are made. Table 6.1 illustrates the four possible decisions; two are correct and two are incorrect. 
Table 6.1. Decision Error Matrix

\begin{tabular}{|c|c|c|}
\hline \multirow{2}{*}{ Decision Based on Data } & \multicolumn{2}{|c|}{ Trae State of Nafure } \\
\hline & H, is True & H. is False \\
\hline Accept $\mathrm{H}_{0}$ & Correct Decision & Type II error \\
\hline Reject $\mathrm{H}_{0}$ & Type I Error & Correct Decision \\
\hline
\end{tabular}

$\mathrm{H}_{0}=$ the tank waste concentration is less than or equal to the envelope limit.

For the specified hypotheses $\left(\mathrm{H}_{0}=\right.$ the tank waste concentration is less than or equal to the envelope limit and $\mathrm{H}_{\mathrm{a}}=$ the tank waste concentration is greater than the envelope limit) the Type I error states the waste concentration is outside the envelope limit when it is actually inside the envelope limit. The Type II error states the waste concentration is within the envelope limit when it is actually outside the envelope limit. It is necessary to specify the probability of both the Type I and Type II error.

In the following analysis, numbers of individual tank samples were assessed based on historical data. In addition, the effect of the probabilities of Type I and Type II errors, the RSD, and how close the mean analyte concentration is to the envelope specification on the number of composite subsamples required, was assessed. Tables showing the range of values examined are in Appendix B.

\subsubsection{Number of Samples}

6.2.1.1 Individual Tank Samples. The locations of randomly selected tank samples are limited to different depths from existing risers (total randomization is not possible). The number of tank samples can be increased by repeated sampling from a given riser at various depths. Using one riser assumes the lateral tank variability is not significant. Existing data from DST tanks (e.g., AN-105, AN-104, AN-103) has shown that for the majority of the analytes the variability due to riser (lateral variability) is insignificant with respect to the variability between samples or core segments. Therefore, the required sampling procedures specify the numbers of samples per vertical level only. Sampling requirements are described in Section 7.2. In summary, either one core segment or two grab samples per vertical level are required as is possible based on strata thickness.

6.2.1.2 Composite Subsamples. The tables in Appendix B indicate the estimated number of samples needed to test the hypothesis that the waste concentration (for a specified analyte) is less than or equal to the envelope criteria. These tables were generated for use in guiding the selection of the number of composite subsamples that are needed depending on how close the expected tank concentration ( $\hat{\mathbf{R}}$, units of mole analyte/mole $\mathrm{Na}$ ) is to the envelope specification (within $\mathrm{p} \%$ of the envelope limit, where $\mathrm{p}=(\mathrm{EL}-\hat{\mathrm{R}}) / \mathrm{EL}$ and $\mathrm{EL}$ is the envelope limit) and different combinations of tank variability, Type I error probability, and Type II error probability.

Based on this analysis, using three subsamples of the composite are recommended for all initial analyses. This recommendation presumes that the mean of the majority of analytes is not closer than within $30 \%$ of the envelope limit, the probability of Type I and Type II errors is 0.05 , and the RSD for the analysis is $15 \%$ (see Table B.5, Appendix B). If the precision of analysis does not meet the criteria listed in Table 7.1 or the analyte concentration is near the envelope limit and additional data is desired to increase the certainty that the analyte is within envelope specifications, the tables in Appendix B can be used to select an appropriate number of composite subsamples to use for reanalysis of the particular 
analyte based on the concentration and variability data of the initial three subsamples. Additionally, the impact of using different values for the acceptable probability of Type I or Type II errors can be assessed using the tables in Appendix B. 


\subsection{Optimization Guidelines}

This section addresses the requirements for grab and core sample collection, solids/liquid separation, preparation of composites, sample characterization, quality assurance/quality control (QA/QC) requirements, and reporting requirements. A flowsheet of the primary sampling and analysis activities is presented in Figure 7.1.

The major requirements of this DQO, in terms of sampling and analysis are described in this section. These requirements are summarized as follows:

- determination of supernate homogeneity

- collection of representative supernate and solid samples based on retrieval sequence information, stratification information, and statistical considerations

- maintenance of records of sample characteristics

- liquid/solid separation and quantification of physical parameters for each fraction

- preparation of liquid and solid fraction composites according to relative wt $\%$ of individual sample fractions compared to total amount of each fraction collected

- analysis of the liquid and solids composites for the analytes selected in this DQO process

- estimation of solids solubility for the tank solids that are a candidate for dissolution in the potential tank retrieval sequence specific to each tank.

The data collected based on the above requirements are subject to the QA/QC requirements delineated in this section. These data are then reported and analyzed with respect to Privatization Contract envelope specifications using the procedures outlined in Section 7.7 to meet the objectives of this DQO as described in Sections 1.0 and 2.0.

\subsection{Planning Assumptions}

Samples are to be collected from three general strata types when such strata types are present. The three strata will be referenced in this DQO as: crust, supernate, and solids (refer to Figure 7.2). Strata may comprise more than one level as indicated on the figure. Note that the crust is generally the same composition as settled solids in the same waste tank. Supernate strata may also contain some precipitated solids. These entrained solids may or may not be soluble if the supernate is diluted. The settled solids may contain either or both insoluble solids or crystallized supernate composition compounds. The settled solids will contain interstitial supernate. The LAW Phase I feed will be composed of the soluble fraction, with up to $2 \mathrm{wt} \%$ insoluble solids. 
Generally, the tank waste supernate liquid fraction is expected to be homogeneous given the current information available on the priority Phase I LAW candidate waste feed tanks. For planning purposes, a "generic model" with three strata types (crust, supernate, and solids) is proposed. In the generic model, samples are retrieved from one riser at five to seven levels; the samples are distributed equally (i.e., equidistant from each other) along the vertical axis.

A minimum of two grab samples or one core segment must be collected for each level. More than two grab samples/one segment at each level may be required to fulfill sample volume requirements. The following planning basis has been applied to the sampling and characterization strategy:

1. The mobilization and retrieval strategy will be dependent on the tank waste properties and tank waste volume. Mobilization and retrieval may occur in multiple steps, wherein sequential fractions of the candidate LAW feed would be distributed. Depending on the tank waste volume, dilution may occur in-line during transfer or intank before transfer, for part or all of the tank waste. In some cases, no dilution may be required for transfer. The sampling and waste characterization strategy implemented for this DQO will require a preliminary assessment of the predicted tank waste strata and potential mobilization and retrieval sequence, on a tank-by-tank basis, so that appropriate sampling locations can be determined.

2. For planning purposes, the supernate liquid fraction will be considered homogenous if the variability within the supernate strata is less than or equal to $20 \%$ for $\mathrm{Na}, \mathrm{Al}$, and ${ }^{137} \mathrm{Cs}$ (see PNNL 1997 for discussion). A liquid composite and a solid composite will be used for analysis if strata homogeneity criteria are satisfied. If homogeneity criteria are not satisfied, composites representing individual strata are to be prepared.

3. A solids solubility screening test will provide an indication of the portion of candidate solids (i.e., solids to be retrieved) within each tank that is soluble and the components of the solids that are soluble based on a standardized dilution procedure. These data will be used in assessing the impact of solids on meeting Privatization Contract envelope specifications and will provide input to aid in designing solids dissolution testing for waste retrieval. Analysis for the solubility of the solids will be limited to selected analytes as described in Section 7.5.3.

\subsection{Grab and Core Sample Collection}

A generic grab and core sampling scheme is presented in Figure 7.2. For each tank, the location of samples, the number of samples, and the portion of the tank solids considered for inclusion in sampling for application to this DQO must be determined based on the potential retrieval sequence for the specific tank. If the supernate is determined to be non-homogeneous or distinct layers of solids are present and are applicable to LAW feed based on potential retrieval sequences, the sampling scheme must be modified to accommodate separate sampling of each distinct layer. The general sampling guidelines that apply to sampling for each layer require sampling at one vertical level for crust material, three vertical levels (top, middle, and bottom) for the supernate or for each distinct layer within the supernate as is possible based on layer thickness, and one vertical level for the solids or for each distinct layer within the solids. Only solid 
layers relevant to LAW feed retrieval will be sampled. If solids will not be retrieved per LAW feed retrieval, no solid layer sample is required.

Grab sampling is acceptable when tank waste characteristics allow access and retrieval by this method. A minimum of two grab samples must collected for each level. If the tank waste is core sampled, a minimum of one segment from each level will be collected. However, a sufficient quantity of sample is to be collected from each strata/substrata to support the requested analysis, solids screening tests, and archive.

\subsection{Solids/Liquid Separation}

For each individual sample (grab sample jars or sample jars from core segments) the following data are required after a settling time of greater than 16 hours.

- total sample weight and volume

- estimated volume percent (vol\%) settled solids

- Visual observations, including:

- presence of floating layers (organics or solids)

- any indications of gas generation within the sample.

The liquids and solids from each bottle/jar are to be separated by centrifugation or filtration. The contents of the grab sample bottles representing a strata (vertical level) may be composited at this stage to facilitate subsequent separation steps. Dilution of the sample is to be minimized during all transfers by rinsing of bottles or jars with the separated liquid fraction, whenever possible. The following data are required.

- the method used for solid/liquid separation

- composition and quantity of alternative rinse solution (if other than the tank liquid fraction)

- weight of the separated liquid and "wet" solid fractions

- the "wet" wt\% solids (with respect to liquid) in the individual samples/segments and the liquid and solid wt\% of each sample segment with respect to the total solids from all samples/segments.

\subsection{Liquid and Solid Composites}

Separate composites of the liquid and solid fractions are to be prepared. Multiple composites of the supernate are required if the supernate is determined to be non-homogeneous. The supernate is nonhomogeneous if the variability (RSD) in the mean concentrations of $\mathrm{Na}, \mathrm{Al}$, and ${ }^{137} \mathrm{Cs}$ between the 
supernate substrata is greater than $20 \%$. Similarly, if the solids to be retrieved are composed of distinct substrata (layers), compositing of each substrata are required for each substrata applicable to LAW feed.

To prepare the liquid composite, aliquots of the liquid fraction from each level are to be combined based on the relative wt\% of liquid in each individual sample compared to the total amount of liquids collected (previously determined in Section 7.3). Record weight of original sample bottle/jar before and after all transfers.

To prepare the solid composite, aliquots of the solid fraction from each level are to be combined based on the relative $w t \%$ of solids in each individual sample compared to the total amount of solids collected (previously determined in Section 7.3). Record weight of original sample bottle/jar before and after all transfers. Excess liquid released during mixing of the solids is to be separated by centrifuging and decanting. Record weight of resulting liquid and solid fractions. The liquid is to be combined with the liquid composite based on the $w t \%$ of the excess liquid in the composite compared to the total amount of liquids collected.

The following data are needed for the completed composites.

- Record weight of composited solids and composited liquids.

- Determine and record the wt\% dissolved solids in the liquid composite.

- Determine the density of the liquid composite.

- Determine the bulk density of the solid composite.

\subsection{Sample Characterization}

Characterization will involve up to three primary activities:

1. characterization of the liquid fraction composite(s)

2. characterization of the solids fraction composite(s)

3. solids solubility screening.

The solids solubility screening activity is implemented for the tank only if the highest measured solidto-liquid ratio in any sample exceeds 0.5 wet wt $\%$ solids. The wet wt $\%$ solids is estimated from the measurements collected in the previous step described in Section 7.3.

\subsubsection{Analysis of Liquid Composite}

A minimum of three subsamples of the liquid fraction composite(s) are to be analyzed for analytes listed in Table 7.1. Duplicates are not required. 
To ensure waste meets specification criteria, TOC must be closely assessed. If the TOC exceeds 5,000 $\mathrm{mg} / \mathrm{L}$, ion chromatography (IC) analysis for the low molecular weight acids, such as oxalate, is required. If the TOC and/or IC results are greater than $40,000 \mathrm{mg} / \mathrm{L}$, analyze the sample by capillary zone electrophoresis, and derivitization/methylene chloride extraction/gas chromatography (GC)/mass spectroscopy (MS) to quantitate low molecular weight acids and complexants.

\subsubsection{Analysis of Solids Composite}

A minimum of three subsamples of the solids fraction composite(s) are to be analyzed for analytes listed in Table 7.1. Duplicates are not required.

\subsubsection{Solids Solubility Screening}

A solids solubility screening test will provide an indication of the portion of candidate solids within each tank that are soluble and the components of the solids that are soluble based on a standardized dilution procedure. The solids solubility screening activity is implemented for the tank only if the highest measured solid-to-liquid ratio in any sample exceeds 0.5 wet wt $\%$ solids. The test will be conducted at ambient temperature ( 25 to 30 degrees $\mathrm{C}$ ) using three dilution ratios with inhibited water as the diluent.

The overall procedures for the solubility screening test are:

1. Prepare four bottles with an aliquot of the solids composite from Section 7.4. Record all component weights and tare weights.

2. The following treatments are to be applied using inhibited water as the diluent.

Bottle 1. 100 parts solid composite and 25 parts diluent

Bottle 2. 100 parts solid composite and 75 parts diluent

Bottle 3. 100 parts solid composite and 100 parts diluent

Bottle 4. 100 parts solid composite and No diluent

3. Mix all bottles for 24 hours.

4. Allow at least 72 hours of settling and then record the estimated vol\% solids.

5. Determine the total sample weight for each bottle.

6. Separate the solids and liquids in each bottle.

7. Determine the weights of the wet solids and liquids for each bottle.

8. Analyze the solids and liquids from each bottle to obtain the concentrations of $\mathrm{Na}, \mathrm{Al}, \mathrm{Cr}$, $\mathrm{P}, \mathrm{S}, \mathrm{Si}, \mathrm{OH}, \mathrm{NO}_{2}, \mathrm{NO}_{3}, \mathrm{Cl}, \mathrm{F}, \mathrm{TIC}, \mathrm{TOC}$, wt $\%$ solids (i.e., dry solids for the solid fraction and percent dissolved solids for the liquid fraction), ${ }^{90} \mathrm{Sr},{ }^{137} \mathrm{Cs},{ }^{60} \mathrm{Co},{ }^{154 / 155} \mathrm{Eu}$, and Total Alpha using the methods and QC parameters outlined in Table 7.1. Determine the density of the liquid fraction. 
Additional requirements for the solubility screening test are to maintain a mass balance, record a log of bottle weights for each transfer, record visual observations of solid properties and gelation at all stages of the test, and record ambient temperature at the beginning, middle, and end of the test.

Measurement of TOC in the undissolved solids is requested as a part of this analyte set. If during the solids screening test (Section 7.5.3), the quantity of solids dissolved is unexplainably lower than expected, analysis for oxalate will be required. The TOC strategy assumes that an explanation for poor dissolution may be the presence of high concentrations of sodium oxalate (Brooks et al. 1997). This strategy also assumes that oxalate insoluble in the tank waste matrix can be measured by current analytical methods.

\subsection{Project-Specific Analytical Quality Assurance and Quality Control Requirements}

Analytical data requested as a result of this DQO process are judged to be within the scope of the Hanford Analytical Services Quality Assurance Requirements Documents (HASQARD) (DOE-RL 1997), Section 1.1.1. Except for specific requirements listed in this DQO, analytical work shall conform to HASQARD requirements. If exceptions are required by matrix or radioactivity concerns, a full description of the operation as conducted shall be documented and included in the data report.

To the extent technically reasonable, "spike recovery" will be performed to assess the accuracy of the analytical method. Overall estimates of precision and accuracy will be determined from a statistical analysis of the data sets. Because the sample presents a high ionic strength, matrix spike results outside the control limit guidance set in HASQARD may not constitute failure of the measurement.

It is understood that the laboratory will follow its internal QC system for required actions whenever QC failures occur. If unusual failures occur, and/or if all analyses cannot be performed (for example, insufficient sample), analysts shall consult with supervisors/customers to determine the proper actions. The laboratory should provide a suggested course of action. All QC failures and limitations on the associated data shall be discussed in the narrative of the data report.

HASQARD control requirements apply with the clarifications given in Sections 7.6.1 through 7.6.4.

\subsubsection{Precision and Variability}

Table 7.1 lists the types of QC parameters for variability along with acceptance criteria. Three subsamples of each composite will be taken through separate preparation procedures and will be analyzed separately.

The RSD will be used as a measure of precision of analysis and as a measure of variability in statistical comparison of appropriate analytes to the Privatization Contract envelope specifications. Repreparation and/or reanalysis of a sample applies to Group 1 analytes whose RSD exceed the criteria in Table 7.1, and whose concentration range is within the contract specification envelope sensitivity boundaries defined as $\pm 30 \%$ of the contract envelope limit. In such circumstances, additional subsamples shall be reprepared and reanalyzed only one time and the results of all analyses reported. The number of additional subsamples to be analyzed will be a function of how close the mean analyte concentration is to the Privatization Contract specification and will be determined based on the statistical tables presented in 
Appendix B. The width of the "sensitivity boundary" relative to the contract envelope limit is based on a statistical analysis of the number of samples needed to meet a specified probability of making a correct assessment of whether the source tank waste is within contract specification limits.

Repreparation and/or reanalysis of Group 2 analytes whose RSD performance falls outside the requirements listed in Table 7.1 is not required.

For those analytes that exceed the criteria in Table 7.1, the laboratory QA/QC narrative should note the actual RSD and document exceedance with the following comment:

"Relative standard deviation exceeds Table 7.1 acceptance criteria but reanalysis is not required because analyte concentrations are outside of the sensitivity bounds defined as \pm 30 percent envelope limit or analyte is not included in the envelope limit." (Include citation to this DQO.)

\subsubsection{Accuracy}

7.6.2.1 Matrix Spike. Matrix spikes are used to assess the accuracy of the method on the matrix. A known concentration is added to the sample before chemical preparation of the sample and the percent recovery is measured to assess accuracy. If the analyte is routinely high in concentration such as $\mathrm{Na}$ or aluminum, a serial dilution will be performed instead of a matrix spike (see Section 7.6.2.2). This is because spiking a compound/element that is already very high in concentration does not allow assessment of accuracy.

If the percent recovery of the matrix spike exceeds criteria in Table 7.1 and if the analyte is part of Group 1, reanalysis is required. If the percent recovery of the matrix spike exceed criteria in Table 7.1, and if the analyte is part of Group 2, reanalysis/repreparation is not required.

For analytes in Group 2 that exceed the criteria listed in Table 7.1, the laboratory QA/QC narrative should note the actual recoveries and document exceedance with the following comment:

"Matrix spike exceeds Table 7.1 acceptance criteria but reanalysis is not required because the analyte is not included in the contract specification envelope limit." (Include citation to this DQO.)

7.6.2.2 Serial Dilutions. For analytes such as $\mathrm{Na}$ and aluminum, a serial dilution must be performed to assess the accuracy of the analysis method if a matrix spike technique is not possible. The percent difference between each of three serial dilution concentration determinations must be less than or equal to $10 \%$ for all analytes except $\mathrm{Na}$ which must have a percent difference less than or equal to $5 \%$.

7.6.2.3 Accuracy Requirements for HAW Performance Assessment. Table 7.2 summarizes the set of rules developed to define the accuracy required for chemical analysis of tank waste in support of the LAW DQO for PA. The radionuclides of interest for each of the two PA drivers, groundwater and intruder, are listed. Accuracy requirements are divided into three classes as a function of the predicted isotope concentration in the tank waste. The predicted tank waste concentration $(\mathrm{X})$ is the standard inventory (Kupfer 1997) for the tank at the time of sampling. Where the class 2 and class 3 rules specify either 0.1 times the tank average concentration or the detection limit, the value is the larger of the two. In those cases 
where the detection limit is known and it is larger than the 0.1 times the tank average concentration, the detection limit is used for the bounding condition.

Table 7.3 shows all key radionuclides of the ILAW PA, the expected tank concentration, and the estimated detection limit.

\subsubsection{Laboratory Control Standard}

The material used as the laboratory control standard (LCS) shall conform to the requirements of HASQARD. Depending on the analysis, this may be a spiked preparation blank, blank spike, or a certified laboratory control sample material. If required, reanalysis shall be done on one sample. The results of all determinations shall be reported. The LCS results shall meet the criteria in Table 7.1 and HASQARD. If the LCS exceeds criteria in Table 7.1, the laboratory shall reanalyze or reprepare, as appropriate, the samples processed in the same batch.

Method blanks will be analyzed per each sample batch and will be carried through the appropriate sample preparation and analyses in the same manner as the samples.

\subsubsection{Minimum Reportable Quantities}

Table 7.4 provides minimum reportable quantities (MRQs) for the analytes specified in Table 7.1 of this DQO. These values are based on the analytical methods indicated for each analyte in Table 7.1. These values are a guide for determining the required analytical sensitivity for reporting results in support of this DQO. The MRQs were selected to meet the objectives of the DQO with consideration given to the estimated quantitation limits (EQLs) and minimum detectable activities (MDAs) based on current laboratory practices. The MRQs, with some exceptions, meet the DQO objective that the MRQ be less than or equal to one tenth of the envelope limit for Group 1 analytes (based on a calculation using a sodium concentration of $7 \mathrm{M}$ ). The practical quantitation limits (PQLs) from individual tanks may not meet the EQLs depending on the sodium concentration or other matrix effects. Based on a sodium concentration of $7 \mathrm{M}$, the TRU components do not currently meet this goal.

For the TRU components, the concentrations of all of the components are summed to compare to the TRU envelope limit. The DQO goal is that the sum of the individual MRQs for TRU components is less than $35 \%$ of the TRU envelope limit. It is recognized that the sum of the EQLs for TRU components listed in Table 7.4, which are based on current analysis methods, may not meet this goal. In some cases, Total Alpha may be used as an indicator that the concentration of TRU is less than the TRU envelope. For this purpose, the concentration data for Total Alpha should be compared to the envelope specification for TRU using the analysis steps described in section 7.7.2 and reported in conjunction with the data and analysis for TRU.

The EQL, as it is defined in this DQO, takes into account the method of analysis, instrumentation detection limit, and typical preparation/dilution required for the expected tank waste matrices. The preparation/dilution is dependent on the amount of solids, the concentration of the highest analyte in a multianalyte method, and the concentration of any interfering analytes in the samples. The EQLs in Table 7.4 were determined based on either laboratory instrument detection limits multiplied by the expected dilution or on the results of previous analyses (Tanks AW-101, AN-107 and AN-105). 
The MDA depends on the concentration of interfering radionuclides and on the duration of the analysis of the sample. In many cases, the required MDA can be achieved by increasing the duration of the analysis. The MDAs for Table 7.4 based on the results of previous analyses (Tanks AW-101, AN-107 and AN-105).

The MRQs for this DQO are defined as three times the EQL or MDA for each analyte and are specific to the analysis of dissolved solids in the liquid composite. For analyses of the solid composite, the MRQs determined for liquid analyses are multiplied by 100 as indicated in the footnote of Table 7.4. This factor is necessary to account for the additional dilution required for preparation and analysis of solid samples.

If the laboratory cannot meet the MRQs using the methods indicated in Table 7.1 or by using an alternative standard laboratory procedure that is more sensitive, the PQL (the detection limit, corrected for matrix affects, that was achieved during analysis) must be reported with a notation describing why the MRQ was not met (e.g., due to sample matrix, dilution, solids content or dose rate).

\subsection{Data Reduction Methodology and Reporting}

\subsubsection{Laboratory Assessment and Report}

While it is imperative that all data be produced following approved procedures, it should be recognized that these are unique materials and some modifications to standard operating procedures may be required to generate technically valid analytical data. If such modifications are necessary, they must be clearly documented following the required protocols.

The data report shall show the precision (RSD) and accuracy (spike recovery or serial dilution results) of the data. All analytes requiring reruns are to be explained in the case narrative. All raw data supporting such reruns shall be archived and available for review.

The summary of the QC data will be reported. The supporting raw data will be on file in the laboratory for review as needed. The QC report will include RSD, spike recovery, LCS recovery, method blank results, any physical observations related to the sample, and any QC problems or anomalies. Sample reporting limits and detection limits will be reported.

All analytical and supporting QA/QC results will undergo a one-over-one technical review before the data report is issued to the TWRS Privatization Project. An independent data validation (an administrative review of laboratory documents conducted for supporting regulatory compliance requirements) is not required for data developed under this DQO. The U.S. DOE National Nuclear Data Center, Brookhaven National Laboratory should be used to obtain values of parameters for radionuclide data unit conversion (www.nndc.bnl.gov).

The laboratory report to the TWRS privatization project shall include:

1. standard laboratory Format IV data package or equivalent 
2. all specific laboratory data requested in Section 7.0 of this DQO (e.g., sample handling including description of compositing, analytes in Table 7.1, and solubility screening in Section 7.5.3, as applicable)

3. extrusion report for cores

4. a description of any variation to the requirements set forth in this DQO

5. QA/QC report as defined in this DQO.

\subsubsection{Statistical Approach, Treatment of the Data, and Report}

One of the major objectives of the efforts described in this DQO is to characterize tank waste with respect to the Privatization Contract LAW feed envelope specification limits. As part of this characterization, a statistical analysis of the data is required to estimate confidence intervals on the mean analyte concentration for envelope analytes. The objective of the statistical analysis is to make a comparison of the mean analyte concentration and the upper limit of a $95 \%$ confidence interval for the mean analyte concentration to the Privatization Contract LAW feed envelope specification limits. An outline of the statistical methodology to be used in preparing envelope comparisons is presented in Appendix C. This comparison is required for two sets of data.

- envelope analyte concentrations from analysis of the liquid fraction composite

- estimated envelope analyte concentrations for a mathematically calculated tank composite.

An estimate of the analyte concentrations in the tank composite is calculated by assuming that all of the analytes in the solids composite are soluble. Using the vol\% of supernate and candidate solids for the tank, the weighted average concentration of an analyte in the tank can be calculated. Concentrations of analytes in the solids (reported as $\mu \mathrm{g} / \mathrm{g}$ or $\mu \mathrm{Ci} / \mathrm{g}$ ) are to be converted to $\mu \mathrm{g} / \mathrm{mL}$ or $\mu \mathrm{Ci} / \mathrm{mL}$ using the measured bulk density of the solids.

In some cases, Total Alpha may be used as an indicator that the concentration of TRU is less than the TRU envelope specification. For this purpose, the concentration data for Total Alpha should be compared to the envelope specification for TRU using the analysis steps described in section 7.7.2 and reported in conjunction with the data and analysis for TRU.

The units for the envelope limits are mole analyte/mole $\mathrm{Na}$ or Becquerel analyte/mole $\mathrm{Na}$. To compare the analytical results to the envelope limits the analyte mean concentration units are converted to mole or Becquerel. The estimate of the ratio mole analyte/mole $\mathrm{Na}$ or Becquerel analyte/mole $\mathrm{Na}$ is the ratio mean mole analyte/mean mole $\mathrm{Na}$ or mean Becquerel analyte/mean mole $\mathrm{Na}$. The variance for this ratio to $\mathrm{Na}$ is an approximation (an exact confidence interval cannot be calculated) and assumes that the analyte concentrations are independent of the $\mathrm{Na}$ concentration.

The approach for performing a statistical comparison of analyte concentration data to the envelope specification is outlined below. In this approach, three different comparisons are performed. The first 
requirement is to compare the ratio of the mean analyte concentration and the mean sodium concentration, (R), for each applicable analyte to the envelope specifications. This requirement addresses the specific comparison described in the Privatization contract specification. The second requirement is to compare the upper limit of an approximate one-sided $95 \%$ confidence interval for $\mathrm{R}$ considering only the random variability in the data. If the upper limit of this approximate $95 \%$ confidence interval is above the envelope limit but $R$ is not, then additional composite subsamples may need to be analyzed (see Appendix C). The third requirement is to compare the upper limit of an approximate one-sided 95\% confidence interval for $R$ considering both random and systematic variability in the data. Systematic variability for the purposes of this DQO will be used as an estimate of bias in the laboratory of the samples and will be calculated from the matrix spike recovery data, the serial dilution data, or reference standards data, as described in Appendix C. If the upper limit of this $95 \%$ confidence interval is above the envelope limit but $\mathrm{R}$ is not, then the interpretation of these data or requirements for additional analyses will require further review by technical staff to assess the potential impacts of analytical bias in the use of these data.

A statistical report to the TWRS privatization project, generated by a statistician knowledgeable to the project, shall include:

1. the mean analyte concentration for each analyte measured

2. the RSD associated with each mean analyte concentration, the number of samples (n), and the $95 \%$ confidence interval for the mean concentration

3. the ratio, $\hat{\mathbf{R}}$; either the mean mole analyte/mean mole $\mathrm{Na}$ or the mean Becquerel analyte/mean mole $\mathrm{Na}$

4. the random and random + systematic variability associated with $\hat{R}$ calculated as described in Appendix C

5. the upper limit of an approximate one-sided $95 \%$ confidence interval for $\hat{R}$ calculated as described in Appendix $\mathrm{C}$ based on the both random and random + systematic variability

6. comparison of $\hat{R}$ and the upper limit of an approximate one-sided $95 \%$ confidence interval for $\hat{R}$ (based on both random and random + systematic variability) to the Privatization Contract LAW feed envelope specification limits

7. discussion of the envelope comparison for analytes that have concentrations less the detection limit times 10 and analytes with concentrations below the detection limit

8. the random and random + systematic variability associated with the $\mathrm{Na}$ concentration data and two-sided $95 \%$ confidence intervals using both the random and random + systematic variability

9. comparison of the mean $\mathrm{Na}$ concentration and two-sided $95 \%$ confidence intervals (based on both random and random + systematic variability) for the $\mathrm{Na}$ concentration to the Privatization Contract feed specifications for $\mathrm{Na}$ concentration. 
10. discussion of the analytical data quality with respect to the requirements outlined in Section 7.6

11. discussion of the strata homogeneity using the criteria outlined in Section 7.4.

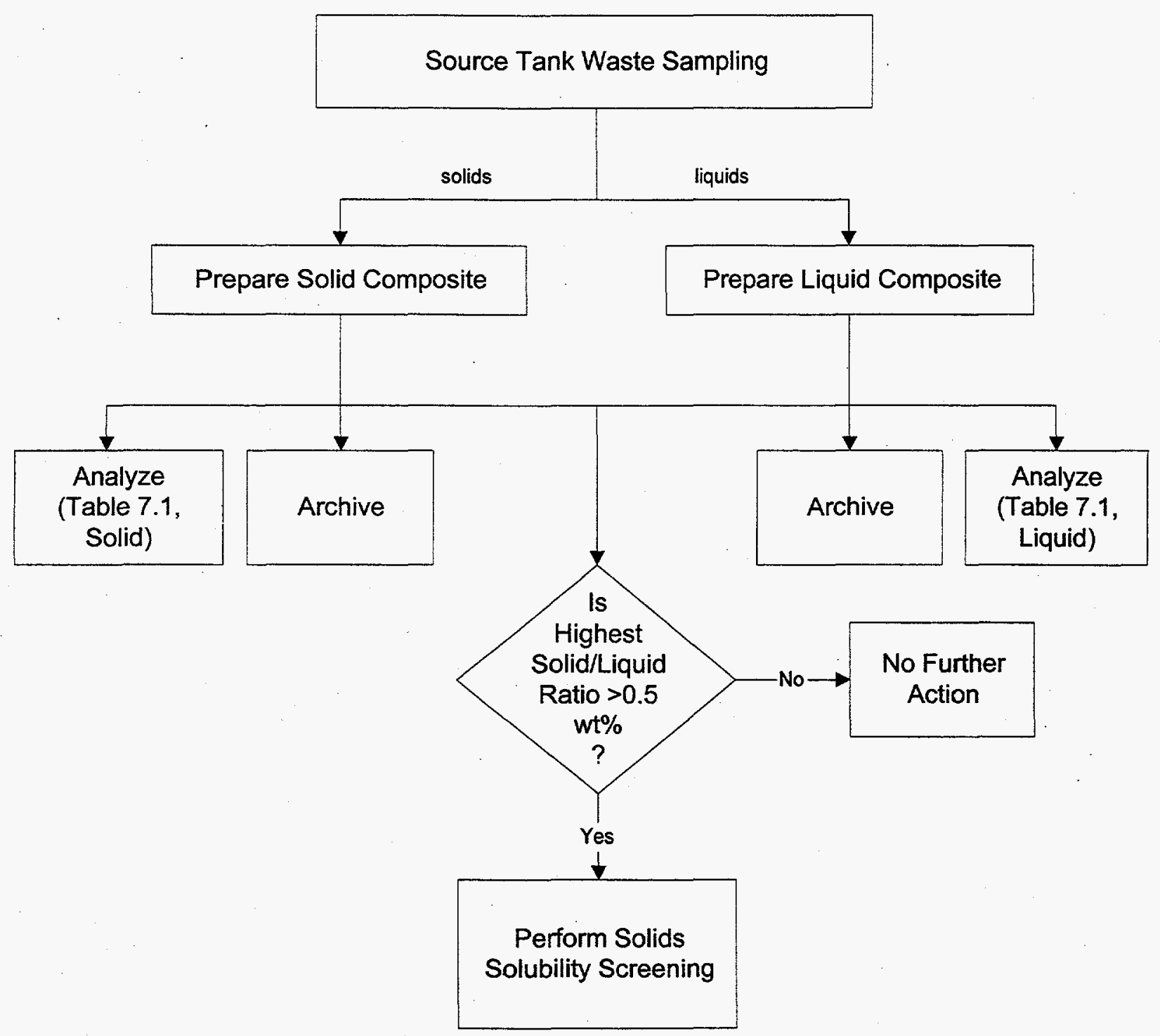

Figure 7.1. Flowsheet for Sampling and Characterization Activities 


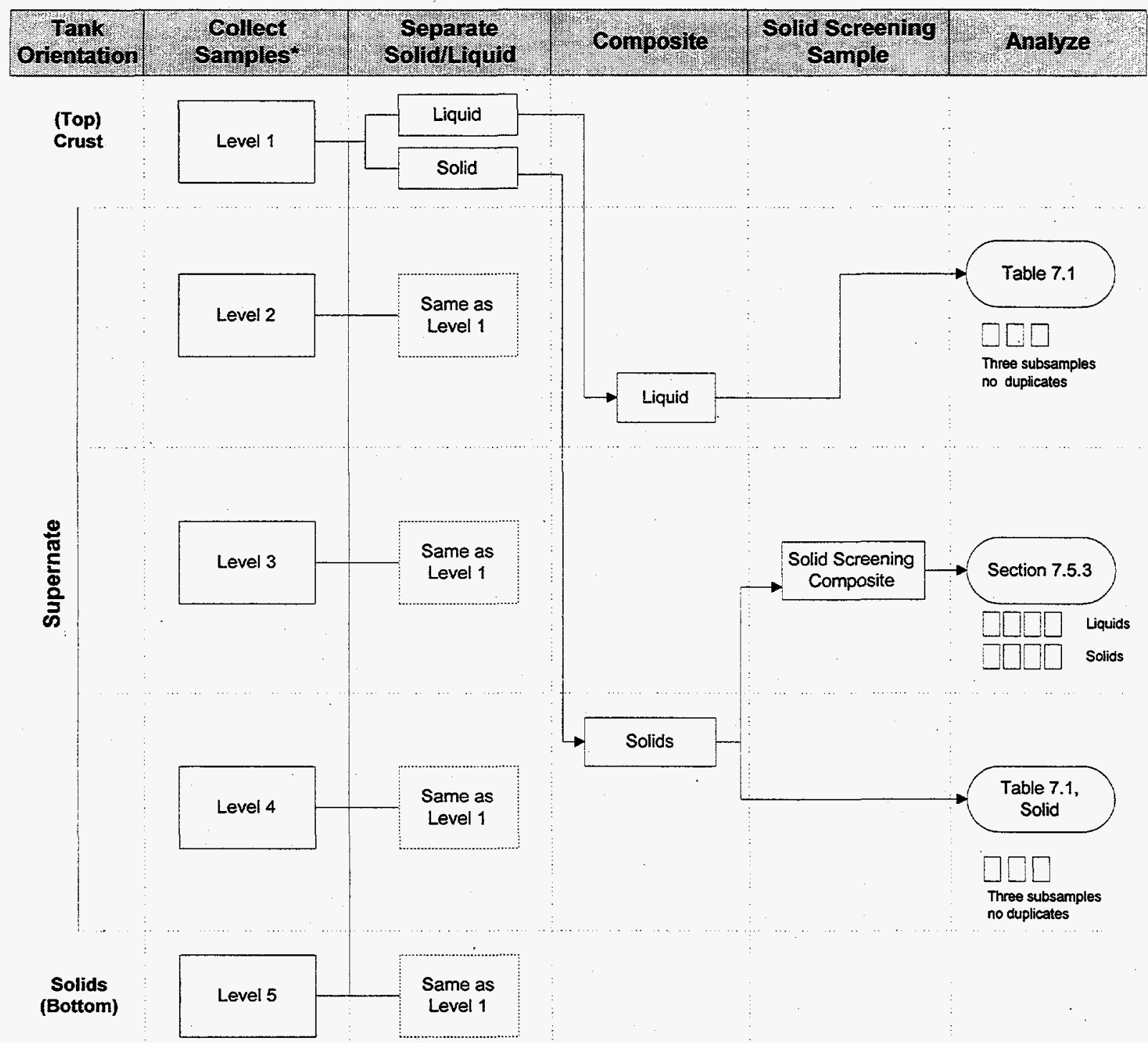

*If core is taken, each level is represented by a minimum of one segment. If grab sampled, each level is represented by a minimum of two grab samples.

Figure 7.2. Sampling Strategy for TWRS Privatization Candidate LAW Feed Source Tank 
Table 7.1. Quality Control Parameters (Page 1 of 3)

\begin{tabular}{|c|c|c|c|c|c|}
\hline \multirow{2}{*}{$\begin{array}{l}\text { Anatytes } \\
\text { Mensured in } \\
\text { Compolid } \\
\text { Comite }\end{array}$} & \multirow{2}{*}{$\begin{array}{l}\text { Aratytes } \\
\text { Measured in } \\
\text { Compositid }^{\text {? }}\end{array}$} & \multirow{2}{*}{$\begin{array}{l}\text { Analytical } \\
\text { Technique }\end{array}$} & \multicolumn{3}{|c|}{ QC Aleceptance Criteria } \\
\hline & & & \%/Recovery & \% Recourery & Buplicate \\
\hline $\begin{array}{l}\mathrm{Ag}, \mathrm{Al}, \mathrm{As}, \mathrm{Bi} \\
\mathrm{Ca}, \mathrm{Cd}, \mathrm{Co}, \mathrm{Cr}, \\
\mathrm{Eu}, \mathrm{Fe}, \mathrm{K}, \mathrm{Mg}, \\
\mathrm{Ni}, \mathrm{P}, \mathrm{Pb}, \mathrm{Pd} \\
\mathrm{Rh}, \mathrm{Ru}, \mathrm{S}, \mathrm{Se} \\
\mathrm{Si}, \mathrm{Sr}, \mathrm{Ti}, \mathrm{U}, \mathrm{Zr}\end{array}$ & $\begin{array}{l}\mathrm{Ag}, \mathrm{Al}, \mathrm{As}, \mathrm{Ca} \\
\mathrm{Cd}, \mathrm{Co}, \mathrm{Cr}, \mathrm{Fe}, \\
\mathrm{K}, \mathrm{Mn}, \mathrm{Ni}, \mathrm{P} \\
\mathrm{Pb}, \mathrm{S}, \mathrm{Se}, \mathrm{Si} \\
\mathrm{Sr}, \mathrm{U}\end{array}$ & ICP/AES & $80-120 \%$ & $75-125 \%$ & $\leq 15 \%$ \\
\hline $\begin{array}{l}\mathrm{NO}_{2}, \mathrm{NO}_{3}, \mathrm{PO}_{4}, \\
\mathrm{SO}_{4}\end{array}$ & $\begin{array}{l}\mathrm{NO}_{2}, \mathrm{NO}_{3} \\
\mathrm{PO}_{4}, \mathrm{SO}_{4} \\
\end{array}$ & IC & $80-120 \%$ & $75-125 \%$ & $\leq 15 \%$ \\
\hline \multirow[t]{2}{*}{${ }^{99} \mathrm{Tc}$ (total) } & ${ }^{99} \mathrm{Tc}$ (total) & ICP/MS & $80-120 \%$ & $70-130 \%$ & $\leq 15 \%$ \\
\hline & $\begin{array}{c}{ }^{99} \mathrm{Tc} \\
\text { (pertechnetate) }\end{array}$ & separation/ beta count & $80-120 \%$ & $70-130 \%$ & $\leq 15 \%$ \\
\hline $\mathrm{Na}$ & $\mathrm{Na}$ & ICP/AES & $80-120 \%$ & $75-125 \%$ & $\leq 3.5 \%$ \\
\hline $\mathrm{Hg}$ & $\mathrm{Hg}$ & CVAA & $80-120 \%$ & $75-125 \%$ & $\leq 15 \%$ \\
\hline \multirow[t]{2}{*}{$\mathrm{F}, \mathrm{Cl}$} & $\mathrm{F}, \mathrm{Cl}$ & IC & $80-120 \%$ & $75-125 \%$ & $\leq 15 \%$ \\
\hline & $\mathrm{NH}_{4} / \mathrm{NH}_{3}$ & ISE, colorimetric & $80-120 \%$ & $75-125 \%$ & $\leq 15 \%$ \\
\hline $\mathrm{OH}$ & $\mathrm{OH}$ & Potentiometric titration & $80-120 \%$ & N/A & $\leq 15 \%$ \\
\hline $\begin{array}{c}\text { Total } \\
\text { Inorganic } \\
\text { Carbon } \\
\end{array}$ & $\begin{array}{c}\text { Total } \\
\text { Inorganic } \\
\text { Carbon } \\
\end{array}$ & $\begin{array}{l}\text { persulfate and } \\
\text { combustion furnace }\end{array}$ & $80-120 \%$ & $75-125 \%$ & $\leq 15 \%$ \\
\hline TOC & TOC $^{11}$ & $\begin{array}{l}\text { silver catalyzed } \\
\text { persulfate and } \\
\text { combustion furnace }\end{array}$ & $80-120 \%$ & $75-125 \%$ & $\leq 15 \%$ \\
\hline bulk density & density & & $\mathrm{N} / \mathrm{A}$ & N/A & $\mathrm{N} / \mathrm{A}$ \\
\hline Wt $\%$ solids & Wt\% solids & gravimetric & $80-120 \%$ & N/A & $\leq 21 \%$ \\
\hline${ }^{90} \mathrm{Sr}$ & ${ }^{90} \mathrm{Sr}$ & $\begin{array}{l}\text { isotopic specific } \\
\text { separation/beta count }\end{array}$ & $75-125 \%$ & $N / A^{4}$ & $\leq 15 \%$ \\
\hline${ }^{237} \mathrm{~Np}$ & ${ }^{237} \mathrm{~Np}$ & ICP/MS & $90-110 \%$ & $75-125 \%$ & $\leq 15 \%$ \\
\hline $\begin{array}{c}238 / 2391 \\
240 / 242 \mathrm{Pu}\end{array}$ & $\begin{array}{c}238 / 239 / \\
{ }^{240 / 242} \mathrm{Pu}\end{array}$ & ICP/MS & $\begin{array}{l}80-120 \% \\
{ }^{239} \mathrm{Pu} \text { only }\end{array}$ & $\begin{array}{l}70-130 \% \\
{ }^{239} \mathrm{Pu} \text { only }\end{array}$ & $\leq 15 \%$ \\
\hline${ }^{241} \mathrm{Pu} / \mathrm{Am}$ & ${ }^{241} \mathrm{Pu} / \mathrm{Am}$ & ICP/MS & $\begin{array}{l}80-120 \% \\
{ }^{241} \text { Am only }\end{array}$ & $\begin{array}{l}70-130 \% \\
{ }^{241} \text { Am only }\end{array}$ & $\leq 15 \%$ \\
\hline${ }^{241} \mathrm{Am}$ & ${ }^{241} \mathrm{Am}$ & separation/AEA & $80-120 \%$ & $N / A^{4}$ & $\leq 15 \%$ \\
\hline${ }^{242} \mathrm{Cm}^{8}$ & ${ }^{242} \mathrm{Cm}^{8}$ & N/A ${ }^{8}$ & N/A & N/A & N/A \\
\hline $\mathrm{Ba}, \mathrm{La}$ & $\mathrm{Ba}, \mathrm{La}$ & ICP/MS & $80-120 \%$ & $75-125 \%$ & $\leq 15 \%$ \\
\hline
\end{tabular}


Table 7.1. Quality Control Parameters (Page 2 of 3)

\begin{tabular}{|c|c|c|c|c|c|}
\hline \multirow{2}{*}{$\begin{array}{l}\text { Measulyted } \\
\text { Solid } \\
\text { Composite }\end{array}$} & \multirow{2}{*}{$\begin{array}{l}\text { Analytes } \\
\text { Measured in } \\
\text { Liquid } \\
\text { Composite }\end{array}$} & \multirow{2}{*}{$\begin{array}{l}\text { Analytical } \\
\text { Techinique }\end{array}$} & \multicolumn{3}{|c|}{ QC Acceptance Griteria } \\
\hline & & & \%ress & \% Recovert & $\begin{array}{l}\text { Buplicate } \\
\text { RSD }^{3}\end{array}$ \\
\hline${ }^{243} \mathrm{Am} / \mathrm{Cm}$ & ${ }^{243} \mathrm{Am} / \mathrm{Cm}$ & ICP/MS & $90-110 \%$ & $75-125 \%$ & $\leq 15 \%$ \\
\hline \multirow[t]{2}{*}{${ }^{243+244} \mathrm{Cm}$} & ${ }^{243+244} \mathrm{Cm}$ & separation/AEA & $\mathrm{NP}$ & $N / A^{4}$ & $\leq 15 \%$ \\
\hline & $\mathrm{Cs}, \mathrm{Eu}$ & ICP/MS $^{9}$ & $\mathrm{~N} / \mathrm{A}^{9}$ & $N / A^{9}$ & $\mathrm{~N} / \mathrm{A}^{9}$ \\
\hline \multirow[t]{3}{*}{${ }^{137} \mathrm{Cs}$} & ${ }^{137} \mathrm{Cs}$ & GEA & $\mathrm{NP}$ & N/A ${ }^{5}$ & $\leq 15 \%$ \\
\hline & ${ }^{3} \mathrm{H}$ & $\begin{array}{l}\text { separation/liq. } \\
\text { scintillation }\end{array}$ & $80-120 \%$ & $N / A^{4}$ & $\leq 15 \%$ \\
\hline & ${ }^{14} \mathrm{C}$ & $\begin{array}{l}\text { separation/liq. } \\
\text { scintillation }\end{array}$ & $80-120 \%$ & $75-125 \%$ & $\leq 15 \%$ \\
\hline \multirow[t]{5}{*}{${ }^{60} \mathrm{Co}$} & ${ }^{60} \mathrm{Co}$ & GEA $^{10}$ & $80-120 \%$ & $N / A^{5}$ & $\leq 15 \%$ \\
\hline & ${ }^{79} \mathrm{Se}$ & liq. scintillation & NP & N/A ${ }^{4}$ & $\leq 15 \%$ \\
\hline & ${ }^{126} \mathrm{Sn}$ & ICP/MS & \multicolumn{3}{|c|}{ Developed by Laboratory } \\
\hline & ${ }^{129} \mathrm{I}$ & separation/GEA & $80-120 \%$ & $75-125 \%$ & $\leq 15 \%$ \\
\hline & ${ }^{125} \mathrm{Sb}$ & GEA & \multicolumn{3}{|c|}{ Developed by Laboratory } \\
\hline${ }_{.154}^{15 u}$ & ${ }^{154} \mathrm{Eu}$ & GEA $^{10}$ & $\mathrm{NP}$ & $N / A^{5}$ & $\leq 15 \%$ \\
\hline \multirow[t]{7}{*}{${ }^{155} \mathrm{Eu}$} & ${ }^{155} \mathrm{Eu}$ & $\mathrm{GEA}^{10}$ & $\mathrm{NP}$ & $\mathrm{N}^{\prime} \mathrm{A}^{5}$ & $\leq 15 \%$ \\
\hline & ${ }^{231} \mathrm{~Pa}$ & ICP/MS & \multicolumn{3}{|c|}{ Developed by Laboratory } \\
\hline & ${ }^{233} \mathrm{U}$ & ICP/MS & $90-110 \%$ & $75-125 \%$ & $\leq 15 \%$ \\
\hline & ${ }^{234} \mathrm{U}$ & ICP/MS & $90-110 \%$ & $75-125 \%$ & $\leq 15 \%$ \\
\hline & ${ }^{235} \mathrm{U}$ & ICP/MS & $90-110 \%$ & $75-125 \%$ & $\leq 15 \%$ \\
\hline & ${ }^{236} \mathrm{U}$ & ICP/MS & $90-110 \%$ & $75-125 \%$ & $\leq 15 \%$ \\
\hline & ${ }^{238} \mathrm{U}$ & ICP/MS & $80-120 \%$ & $70-130 \%$ & $\leq 15 \%$ \\
\hline Total Alpha & Total Alpha & proportional counter & $70-130 \%$ & $70-130 \%$ & $\leq 15 \%$ \\
\hline
\end{tabular}


Table 7.1. Quality Control Parameters (Page 3 of 3)

Notes:

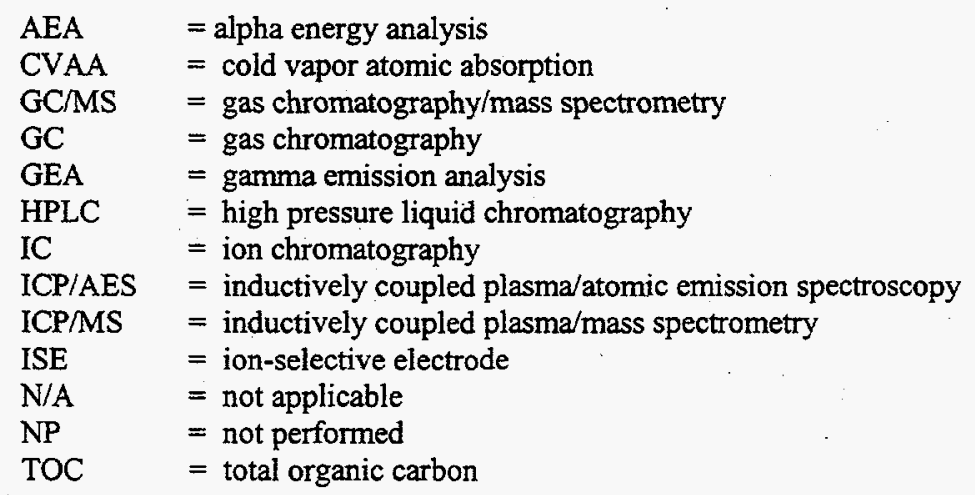

${ }^{1} \mathrm{LCS}=\mathrm{Laboratory}$ Control Standard. This standard is carried through the entire method. The accuracy of a method is usually expressed as the percent recovery of the LCS. The LCS is a matrix with known concentration of analytes processed with each preparation and analyses batch. It is expressed as percent recovery; i.e., the amount measured, divided by the known concentration, times 100 .

${ }^{2}$ For some methods, the sample accuracy is expressed as the percent recovery of a matrix spike sample. It is expressed as percent recovery; i.e., the amount measured, less the amount in the sample, divided by the spike added, times 100. One matrix spike is performed/analytical batch samples are batched with similar matrices. For other analytes, the accuracy is determined based on use of serial dilutions as described in Section 7.6.2.2.

${ }^{3} \mathrm{RSD}=$ Relative Standard Deviation between the samples. Sample precision is estimated by analyzing replicates taken separately through preparation and analysis. Acceptable sample precision is usually $<14$ percent RSD if the sample result is at least 10 times the instrument detection limit.

$$
\mathrm{RSD}=(\text { standard deviation of the mean } / \text { mean }) \times 100
$$

${ }^{4}$ Matrix spike analyses are not required for this method because a tracer is used to correct for analyte loss during sample preparation and analysis. The result generated using the tracer accounts for an inaccuracy of the method on the matrix. The reported results reflect this correction.

${ }^{5}$ The measurement is a direct reading of the energy and the analysis is not affected by the sample matrix; therefore, a matrix spike is not required.

${ }^{6}$ All samples must be digested using the appropriate SW 8463000 series method prior to metals analyses.

${ }^{7}$ This method or the most recent promulgated version of the SW 846 method should be used.

${ }^{8}$ This isotope can not be quantitated because of the short half-life and correspondingly large specific activity. On the ICP/MS, any mass observed at 242 is assumed to be Pu-242 because of the longer half-life.

${ }^{9}$ Total $\mathrm{Cs}$ and $\mathrm{Eu}$ are sums of all isotopes, therefore spiking and LCS does not apply.

${ }^{10}$ An extended counting time in presence of high ${ }^{137} \mathrm{Cs}$ activity may be required to achieve the minimum reportable quantity for ${ }^{60} \mathrm{Co}$ and ${ }^{154 / 155} \mathrm{Eu}$.

${ }^{11}$ Analysis for oxalate may be required as described in section 7.5.1.

${ }^{12}$ Analytes for the Solubility Screening Test are a subset of this analyte list. Refer to section 7.5.3. 
Table 7.2. Rules for Determining Accuracy Requirements for ILAW Performance Assessment Data

\begin{tabular}{|c|c|c|}
\hline & Groundwater & Intruder \\
\hline Key Radionuclides & ${ }^{79} \mathrm{Se},{ }^{99} \mathrm{Tc},{ }^{231} \mathrm{~Pa},{ }^{233} \mathrm{U},{ }^{234} \mathrm{U},{ }^{235} \mathrm{U},{ }^{238} \mathrm{U}$ & ${ }^{126} \mathrm{Sn},{ }^{241} \mathrm{Am},{ }^{239} \mathrm{Pu}$ \\
\hline \multirow[t]{2}{*}{ Class 1} & $\begin{array}{l}X \leq(0.25 \times \text { average tank } \\
\text { concentration })\end{array}$ & $\begin{array}{l}X \leq(0.1 \times \text { average tank } \\
\text { concentration })\end{array}$ \\
\hline & $\begin{array}{l}\text { Need accuracy of } \pm 10 \% \text { of } \\
\text { measurement }\end{array}$ & $\begin{array}{l}\text { Need accuracy of } \pm 10 \% \text { of } \\
\text { measurement }\end{array}$ \\
\hline \multirow[t]{2}{*}{ Class 2} & $\begin{array}{l}\text { either }(0.1 \times \text { average tank } \\
\text { concentration) or detection limit }<\mathrm{X} \\
<0.25 \mathrm{x} \text { average tank concentration }\end{array}$ & $\begin{array}{l}\text { either }(0.1 \mathrm{x} \text { average tank } \\
\text { concentration) or detection limit }<\mathrm{X} \\
<1 \mathrm{x} \text { average tank concentration }\end{array}$ \\
\hline & $\begin{array}{l}\text { Need accuracy of }+25 \% \text { of average } \\
\text { tank concentration }\end{array}$ & $\begin{array}{l}\text { Need accuracy of }+100 \% \text { of average } \\
\text { tank concentration }\end{array}$ \\
\hline \multirow[t]{2}{*}{ Class 3} & $\begin{array}{l}\text { either } X \leq(0.10 \times \text { average tank } \\
\text { concentration }) \text { or detection limit }\end{array}$ & $\begin{array}{l}\text { either } X \leq(0.10 \text { average tank } \\
\text { concentration }) \text { or detection limit }\end{array}$ \\
\hline & $\begin{array}{l}\text { No accuracy specified, measure to } \\
\text { confirm projected value }\end{array}$ & $\begin{array}{l}\text { No accuracy specified, measure to } \\
\text { confirm projected value }\end{array}$ \\
\hline
\end{tabular}

NOTE: Where the estimated detection limit is greater than 0.1 of the average tank concentration, the detection limit is used as the lower bounding condition.

$\mathrm{X}=$ predicted tank waste concentration based on the standard inventory value at the time of sampling. 
Table 7.3. Average Tank Concentration and Estimated Detection Limits for ILAW Performance Assessment Analyte Measurements

\begin{tabular}{|c|c|c|c|}
\hline Radionuclide & $\begin{array}{l}\text { Average Tank } \\
\text { Concentration } \\
\left.(\mathrm{Gi} /)^{\prime}\right)\end{array}$ & $\begin{array}{l}0.1 \text { x Average Tank } \\
\text { Concentration } \\
(\mathrm{CLL})\end{array}$ & Detection limit \\
\hline${ }^{79} \mathrm{Se}$ & $4.88 \mathrm{E}-6$ & $4.88 \mathrm{E}-7$ & $3.00 \mathrm{E}-8$ \\
\hline${ }^{99} \mathrm{Tc}$ & $1.37 \mathrm{E}-4$ & $1.37 \mathrm{E}-5$ & $5.0 \mathrm{E}-07$ \\
\hline${ }^{126} \mathrm{Sn}^{*}$ & $8.36 \mathrm{E}-6$ & $8.36 \mathrm{E}-7$ & $2.00 \mathrm{E}-6$ \\
\hline${ }^{231} \mathrm{~Pa}$ & $7.89 \mathrm{E}-7$ & $7.89 \mathrm{E}-8^{2}$ & No Data \\
\hline${ }^{233} \mathrm{U}$ & $4.13 \mathrm{E}-6$ & $4.13 E-7$ & $1.4 \mathrm{E}-07$ \\
\hline${ }^{234} \mathrm{U}$ & $1.00 \mathrm{E}-5$ & $1.00 \mathrm{E}-6$ & 4.4E-08 \\
\hline${ }^{235} \mathrm{U}$ & $4.42 \mathrm{E}-7$ & $4.42 \mathrm{E}-8$ & $1.5 \mathrm{E}-11$ \\
\hline${ }^{238} \mathrm{U}$ & $1.04 \mathrm{E}-5$ & $1.04 \mathrm{E}-6$ & $2.4 \mathrm{E}-12$ \\
\hline${ }^{239} \mathrm{Pu}$ & $4.43 E-4$ & $4.43 \mathrm{E}-5$ & $3.2 \mathrm{E}-06$ \\
\hline${ }^{241} \mathrm{Am}$ & $5.92 \mathrm{E}-4$ & $5.92 \mathrm{E}-5$ & $1.0 \mathrm{E}-05$ \\
\hline
\end{tabular}

*Denotes radionuclide where detection limit was used instead of 0.1 times the tank average concentration. See Table 7.2.

${ }^{1}$ The concentration data for the key radionuclides listed are based on Revision F of the Best Basis Inventory (BBI) data published in August 1997. This database is available in the TWINS database on the PNNL web page http://twins.pnl.gov:8001/htbin/TCD/getTableList. The radionuclide concentration value for each tank was determined by dividing the inventory data (in $\mathrm{Ci}$ ) by the tank volume (in $\mathrm{L}$ ). The DST volume data from the TCR were used, when available. When the TCR data was not available, and for all SST, the volumes given in Hanlon's Waste Tank Summary Report for Month Ending July 31, 1997, HNF-EP-0182-112, were used. The average tank concentration was determined by averaging the individual tank concentrations over the total number of tanks having inventory data. The BBI global inventory was not used.

${ }^{2}$ For the accuracy requirement rules (refer to Table 7.2), use the measured detection limit in place of ( $0.1 \mathrm{x}$ average tank concentration) if the measured detection limit is greater than $0.1 \mathrm{x}$ average tank concentration. 
Table 7.4. Minimum Reportable Quantities (Page 1 of 3)

\begin{tabular}{|c|c|c|c|}
\hline Analyte & $\begin{array}{l}\text { Estimated Quantitation } \\
\text { Limithimimum }\end{array}$ & Minimum Reportable & Units \\
\hline Ag & $5.5 \mathrm{E}+00$ & $1.7 \mathrm{E}+01$ & $\mu \mathrm{g} / \mathrm{mL}$ \\
\hline Al & $2.5 \mathrm{E}+01$ & $7.5 \mathrm{E}+01$ & $\mu \mathrm{g} / \mathrm{mL}$ \\
\hline As & $5.5 \mathrm{E}+01$ & $1.7 \mathrm{E}+02$ & $\mu \mathrm{g} / \mathrm{mL}$ \\
\hline $\mathrm{Ba}$ & $7.5 \mathrm{E}-01$ & $2.3 \mathrm{E}+00$ & $\mu \mathrm{g} / \mathrm{mL}$ \\
\hline $\mathrm{Bi}$ & $5.5 \mathrm{E}+01$ & $1.7 \mathrm{E}+02$ & $\mu \mathrm{g} / \mathrm{mL}$ \\
\hline $\mathrm{Cd}$ & $2.5 \mathrm{E}+00$ & $7.5 \mathrm{E}+00$ & $\mu \mathrm{g} / \mathrm{mL}$ \\
\hline $\mathrm{Ca}$ & $5.0 \mathrm{E}+01$ & $1.5 \mathrm{E}+02$ & $\mu \mathrm{g} / \mathrm{mL}$ \\
\hline Co & $8.0 \mathrm{E}+00$ & $2.4 \mathrm{E}+01$ & $\mu \mathrm{g} / \mathrm{mL}$ \\
\hline $\mathrm{Cr}$ & $5.0 \mathrm{E}+00$ & $1.5 \mathrm{E}+01$ & $\mu \mathrm{g} / \mathrm{mL}$ \\
\hline Cs, total & $5.0 \mathrm{E}-01$ & $1.5 \mathrm{E} 00$ & $\mu \mathrm{g} / \mathrm{mL}$ \\
\hline $\mathrm{Eu}$ & $2.0 \mathrm{E}+01$ & $6.0 \mathrm{E}+01$ & $\mu \mathrm{g} / \mathrm{mL}$ \\
\hline $\mathrm{Fe}$ & $2.5 \mathrm{E}+01$ & $7.5 \mathrm{E}+01$ & $\mu \mathrm{g} / \mathrm{mL}$ \\
\hline $\mathrm{Hg}$ & $5.0 \mathrm{E}-01$ & $1.5 \mathrm{E}+00$ & $\mu \mathrm{g} / \mathrm{mL}$ \\
\hline $\mathrm{K}$ & $2.5 \mathrm{E}+02$ & $7.5 \mathrm{E}+02$ & $\mu \mathrm{g} / \mathrm{mL}$ \\
\hline $\mathrm{La}$ & $7.5 \mathrm{E}-01$ & $2.3 E+00$ & $\mu \mathrm{g} / \mathrm{mL}$ \\
\hline $\mathrm{Mg}$ & $5.5 \mathrm{E}+01$ & $1.7 \mathrm{E}+02$ & $\mu \mathrm{g} / \mathrm{mL}$ \\
\hline $\mathrm{Mn}$ & $5.5 \mathrm{E}+00$ & $1.7 \mathrm{E}+01$ & $\mu \mathrm{g} / \mathrm{mL}$ \\
\hline $\mathrm{Na}$ & $1.6 \mathrm{E}+04$ & $4.8 \mathrm{E}+04$ & $\mu \mathrm{g} / \mathrm{mL}$ \\
\hline $\mathrm{Ni}$ & $1.0 \mathrm{E}+01$ & $3.0 \mathrm{E}+01$ & $\mu \mathrm{g} / \mathrm{mL}$ \\
\hline $\mathrm{P}$ & $1.1 \mathrm{E}+02$ & $3.3 \mathrm{E}+02$ & $\mu \mathrm{g} / \mathrm{mL}$ \\
\hline $\mathrm{Pb}$ & $9.9 \mathrm{E}+01$ & $3.0 \mathrm{E}+02$ & $\mu \mathrm{g} / \mathrm{mL}$ \\
\hline $\mathrm{Pd}$ & TBD & TBD & $\mu \mathrm{g} / \mathrm{mL}$ \\
\hline $\mathrm{Rh}$ & $6.0 \mathrm{E}+00$ & $1.8 \mathrm{E}+01$ & $\mu \mathrm{g} / \mathrm{mL}$ \\
\hline $\mathrm{Ru}$ & $1.2 \mathrm{E}+01$ & $3.6 \mathrm{E}+01$ & $\mu \mathrm{g} / \mathrm{mL}$ \\
\hline$S$ & $5.5 \mathrm{E}+01$ & $1.7 \mathrm{E}+02$ & $\mu \mathrm{g} / \mathrm{mL}$ \\
\hline $\mathrm{Se}$ & $5.5 \mathrm{E}+01$ & $1.7 \mathrm{E}+02$ & $\mu \mathrm{g} / \mathrm{mL}$ \\
\hline $\mathrm{Si}$ & $3.0 \mathrm{E}+01$ & $9.0 \mathrm{E}+01$ & $\mu \mathrm{g} / \mathrm{mL}$ \\
\hline $\mathrm{Sr}$ & $5.5 \mathrm{E}+00$ & $1.7 \mathrm{E}+01$ & $\mu \mathrm{g} / \mathrm{mL}$ \\
\hline $\mathrm{Ti}$ & $5.5 \mathrm{E}+00$ & $1.7 \mathrm{E}+01$ & $\mu \mathrm{g} / \mathrm{mL}$ \\
\hline $\mathrm{U}$ & $2.60 \mathrm{E}+02$ & $7.8 \mathrm{E}+02$ & $\mu \mathrm{g} / \mathrm{mL}$ \\
\hline $\mathrm{Zr}$ & $5.5 \mathrm{E}+00$ & $1.7 \mathrm{E}+01$ & $\mu \mathrm{g} / \mathrm{mL}$ \\
\hline${ }^{3} \mathrm{H}$ & $7.0 \mathrm{E}-03$ & $2.1 \mathrm{E}-02$ & $\mu \mathrm{g} / \mathrm{mL}$ \\
\hline${ }^{14} \mathrm{C}$ & $2.40 \mathrm{E}-04$ & $7.2 \mathrm{E}-04$ & $\mu \mathrm{Ci} / \mathrm{mL}$ \\
\hline${ }^{60} \mathrm{Co}^{1}$ & $7.0 \mathrm{E}-04$ & $2.1 \mathrm{E}-03$ & $\mu \mathrm{Ci} / \mathrm{mL}$ \\
\hline
\end{tabular}


Table 7.4. Minimum Reportable Quantities (Page 2 of 3)

\begin{tabular}{|c|c|c|c|}
\hline Analyte & $\begin{array}{l}\text { Estimated Quantitation } \\
\text { Gimit/Minimum } \\
\text { Detectable Activity }\end{array}$ & $\begin{array}{c}\text { Minimum Reportable } \\
\text { Quantity (MRO) }\end{array}$ & Units \\
\hline${ }^{79} \mathrm{Se}$ & $3.0 \mathrm{E}-05$ & $9.0 \mathrm{E}-05$ & $\mu \mathrm{Ci} / \mathrm{mL}$ \\
\hline${ }^{89 / 90} \mathrm{Sr}$ & $1.0 \mathrm{E}-02$ & $3.0 \mathrm{E}-02$ & $\mu \mathrm{Ci} / \mathrm{mL}$ \\
\hline${ }^{99} \mathrm{Tc}$ (total) & $5.0 \mathrm{E}-04$ & $1.5 \mathrm{E}-03$ & $\mu \mathrm{Ci} / \mathrm{mL}$ \\
\hline $\begin{array}{l}{ }^{99} \mathrm{Tc} \\
\text { (pertechnetate) }\end{array}$ & TBD & TBD & $\mu \mathrm{Ci} / \mathrm{mL}$ \\
\hline${ }^{125} \mathrm{Sb}$ & $5.6 \mathrm{E}-01$ & $1.7 \mathrm{E}+00$ & $\mu \mathrm{Ci} / \mathrm{mL}$ \\
\hline${ }^{126} \mathrm{Sn}$ & $2.0 \mathrm{E}-03$ & $6.0 \mathrm{E}-03$ & $\mu \mathrm{Ci} / \mathrm{mL}$ \\
\hline${ }^{129} \mathrm{I}$ & $5.8 \mathrm{E}-06$ & $1.8 \mathrm{E}-05$ & $\mu \mathrm{Ci} / \mathrm{mL}$ \\
\hline${ }^{137} \mathrm{Cs}$ & $1.3 \mathrm{E}-01$ & $3.9 \mathrm{E}-01$ & $\mu \mathrm{Ci} / \mathrm{mL}$ \\
\hline${ }^{154} \mathrm{Eu}{ }^{1}$ & $6.5 \mathrm{E}-03$ & $2.0 \mathrm{E}-02$ & $\mu \mathrm{Ci} / \mathrm{mL}$ \\
\hline${ }^{155} \mathrm{Eu}^{1}$ & $3.0 \mathrm{E}-02$ & $9.0 \mathrm{E}-02$ & $\mu \mathrm{Ci} / \mathrm{mL}$ \\
\hline${ }^{231} \mathrm{~Pa}$ & TBD & TBD & $\mu \mathrm{Ci} / \mathrm{mL}$ \\
\hline${ }^{233} \mathrm{U}$ & $1.4 \mathrm{E}-04$ & $4.2 \mathrm{E}-04$ & $\mu \mathrm{Ci} / \mathrm{mL}$ \\
\hline${ }^{234} \mathrm{U}$ & $4.4 \mathrm{E}-05$ & $1.2 \mathrm{E}-04$ & $\mu \mathrm{Ci} / \mathrm{mL}$ \\
\hline${ }^{235} \mathrm{U}$ & $1.5 \mathrm{E}-08$ & $4.5 \mathrm{E}-08$ & $\mu \mathrm{Ci} / \mathrm{mL}$ \\
\hline${ }^{236} \mathrm{U}$ & $4.5 \mathrm{E}-07$ & $1.4 \mathrm{E}-06$ & $\mu \mathrm{Ci} / \mathrm{mL}$ \\
\hline${ }^{237} \mathrm{~Np}^{2}$ & $1.3 \mathrm{E}-05$ & see note 2 & $\mu \mathrm{Ci} / \mathrm{mL}$ \\
\hline${ }^{238} \mathrm{Pu}^{2}$ & $3.2 \mathrm{E}-03$ & see note 2 & $\mu \mathrm{Ci} / \mathrm{mL}$ \\
\hline${ }^{238} \mathrm{U}$ & $2.4 \mathrm{E}-09$ & $7.2 \mathrm{E}-09$ & $\mu \mathrm{Ci} / \mathrm{mL}$ \\
\hline${ }^{239} \mathrm{Pu}^{2}$ & $3.2 \mathrm{E}-03$ & see note 2 & $\mu \mathrm{Ci} / \mathrm{mL}$ \\
\hline${ }^{240} \mathrm{Pu}{ }^{2}$ & $3.2 \mathrm{E}-03$ & see note 2 & $\mu \mathrm{Ci} / \mathrm{mL}$ \\
\hline${ }^{241} \mathrm{Pu} / \mathrm{Am}^{-2}$ & $3.2 \mathrm{E}-03$ & see note 2 & $\mu \mathrm{g} / \mathrm{mL}$ \\
\hline${ }^{242} \mathrm{Pu}^{2}$ & $1.0 \mathrm{E}-02$ & see note 2 & $\mu \mathrm{Ci} / \mathrm{mL}$ \\
\hline${ }^{241} \mathrm{Am}^{2}$ & $1.0 \mathrm{E}-02$ & see note 2 & $\mu \mathrm{Ci} / \mathrm{mL}$ \\
\hline${ }^{243} \mathrm{Am}^{2}$ & 3.2E-03 & see note 2 & $\mu \mathrm{Ci} / \mathrm{mL}$ \\
\hline${ }^{243+244} \mathrm{Cm}^{2}$ & $5.0 \mathrm{E}-02$ & see note 2 & $\mu \mathrm{Ci} / \mathrm{mL}$ \\
\hline $\mathrm{NH}_{4} \mathrm{NH}_{3}$ & $4.5 \mathrm{E}+01$ & $1.4 \mathrm{E}+02$ & $\mu \mathrm{g} / \mathrm{mL}$ \\
\hline $\mathrm{Cl}$ & $1.0 \mathrm{E}+02$ & $3.0 \mathrm{E}+02$ & $\mu \mathrm{g} / \mathrm{mL}$ \\
\hline$F$ & $5.0 \mathrm{E}+01$ & $1.5 \mathrm{E}+02$ & $\mu \mathrm{g} / \mathrm{mL}$ \\
\hline $\mathrm{NO}_{2}$ & $7.5 \mathrm{E}+02$ & $2.3 E+03$ & $\mu \mathrm{g} / \mathrm{mL}$ \\
\hline $\mathrm{NO}_{3}$ & $1.0 \mathrm{E}+03$ & $3.0 \mathrm{E}+03$ & $\mu \mathrm{g} / \mathrm{mL}$ \\
\hline $\mathrm{OH}$ & $2.5 \mathrm{E}+04$ & $7.5 \mathrm{E}+04$ & $\mu \mathrm{g} / \mathrm{mL}$ \\
\hline Oxalate & $6.0 \mathrm{E}+02$ & $1.8 \mathrm{E}+03$ & $\mu \mathrm{g} / \mathrm{mL}$ \\
\hline $\mathrm{PO}_{4}$ & $7.5 \mathrm{E}+02$ & $2.3 E+03$ & $\mu \mathrm{g} / \mathrm{mL}$ \\
\hline
\end{tabular}


Table 7.4. Minimum Reportable Quantities (Páge 3 of 3 )

\begin{tabular}{|c|c|c|c|}
\hline Arialyte & $\begin{array}{l}\text { Estimated Quantitation } \\
\text { I Getectable Activity }\end{array}$ & $\begin{array}{l}\text { Minimum Reportable } \\
\text { Quantity (MRQ) }\end{array}$ & Units \\
\hline $\mathrm{SO}_{4}$ & $7.7 E+02$ & $2.3 E+03$ & $\mu \mathrm{g} / \mathrm{mL}$ \\
\hline Total Alpha & $7.5 \mathrm{E}-02$ & $2.3 \mathrm{E}-01$ & $\mu \mathrm{Ci} / \mathrm{mL}$ \\
\hline $\begin{array}{l}\text { Total Inorganic } \\
\text { Carbon }\end{array}$ & $5.0 E+01$ & $1.5 \mathrm{E}+02$ & $\mu \mathrm{g} / \mathrm{mL}$ \\
\hline $\begin{array}{l}\text { Total Organic } \\
\text { Carbon }\end{array}$ & $5.0 \mathrm{E}+02$ & $1.5 \mathrm{E}+03$ & $\mu \mathrm{g} / \mathrm{mL}$ \\
\hline
\end{tabular}

${ }^{1}$ An extended counting time in presence of high ${ }^{137} \mathrm{Cs}$ activity may be required to achieve the minimum reportable quantity for ${ }^{60} \mathrm{Co}$ and ${ }^{154 / 155} \mathrm{Eu}$.

${ }^{2}$ For the TRU components $\left({ }^{237} \mathrm{~Np},{ }^{238} \mathrm{Pu},{ }^{239} \mathrm{Pu},{ }^{240} \mathrm{Pu},{ }^{241} \mathrm{Am},{ }^{241} \mathrm{Pu} / \mathrm{Am}\right.$ and ${ }^{242} \mathrm{Pu}$, ${ }^{242} \mathrm{Cm},{ }^{243+244} \mathrm{Cm},{ }^{243} \mathrm{Am}$ ), the concentration of all of the components are summed to compare to the TRU envelope limit. The DQO goal is that the sum of the individual minimum reportable quantities for TRU components is less than $35 \%$ of the TRU envelope limit. It is recognized that the sum of the EQLs for TRU components listed in Table 7.4, which are based on current analysis methods, does not meet this goal. In some cases, Total Alpha may be used as an indicator that the concentration of TRU is less than the TRU envelope (see Section 7.7.2).

${ }^{3}$ Listed MRQ values are for liquid analyses. For solid analyses, the MRQ is 100 times the MRQ listed in Table 7.4. 


\subsection{References}

10 CFR 61. "Management and Disposal of Low-Level Wastes by Shallow Land Burial and Alternative Disposal Methods." Code of Federal Regulations, as amended.

40 CFR 141. "National Primary Drinking Water Regulations." Sections 15 and 16. Code of Federal Regulations, as amended.

40 CFR 261.24. "Toxicity Characteristic." Code of Federal Regulations, as amended.

Agnew, SM. 1997. Hanford Tank Chemical and Radionuclide Inventories: HDW Model. Rev. 4. LA-UR-96-3860. Los Alamos National Laboratory, Los Alamos, New Mexico.

Banning, DL. 1997. TWRS Administrative Manual, HNF-IP-0842, Volume IV, "Engineering," Section 4.16, Rev. 0, "Data Quality Objectives for Sampling and Analyses," Lockheed Martin Hanford Company, Richland, Washington.

Brooks, KP, RL Myers, and KG Rappe. 1997. Bench-Scale Enhanced Sludge Washing and Gravity Settling of Hanford Tank C-106 Sludge. PNNL-11432. Pacific Northwest National Laboratory, Richland, Washington.

DOE. 1988. Radioactive Waste Management. DOE Order 5820.2A. US Department of Energy, Washington, DC.

DOE-RL. 1997. Hanford Analytical Services Quality Assurance Requirements Documents.

DOE/RL-96-89. US Department of Energy, Richland Operations Office, Richland, Washington.

DOE-RL. 1998a. Contract Number DE-AC06-96RL13200 - Performance Agreements (PA) TWR1.2.15 and TWR1.2.16. Letter number 98-SCD-027. To HJ Hatch, Fluor Daniel Hanford, Inc. from SA Sieracki, US Department of Energy, Richland Operations Office, dated April 1, 1998. US Department of Energy, Richland Operations Office, Richland, Washington.

DOE-RL. 1998b. BNFL Inc. TWRS Privatization Contract. DE-AC06-96RL113308 - Mod. No. A006, US Department of Energy, Richland Operations Office, Richland, Washington.

Ecology, EPA, and DOE. 1996. Hanford Federal Facility Agreement and Consent Order. As amended. Washington State Department of Ecology, Olympia, Washington; US Environmental Protection Agency and US Department of Energy, Washington, DC.

EPA. 1996. Test Methods for Evaluation Solid Waste Physical/Chemical Methods. SW-846.

3rd Edition. As amended by Updates I (July, 1992), IIA (August, 1993), IIB (January, 1995), and III. US Environmental Protection Agency, Washington, DC.

Galbraith, J. 1996. Alternative Generation of Analysis for Phase I Privatization Transfer Needs. WHC-SD-WM-TI-750. Rev. 0. Westinghouse Hanford Company, Richland, Washington. 
Hanlon, BM. 1998. Waste Tank Summary Report for Month Ending September 1997. WHC-EP-0182-97. Westinghouse Hanford Company, Richland, Washington.

Kirkbride, RA. et al. 1997. Tank Waste Remediation System Operation and Utilization Plan. HNF-SD-WM-SP-012. Rev. 0. Vol. I and II. Numatec Hanford Corporation, Richland, Washington.

Koreski, GM. 1997. Operational Waste Volume Projection. WHC-SD-ER-029. Latest revision. Lockheed Martin Hanford Company, Richland, Washington.

Kupfer, MJ. 1997. Inventories of Chemicals and Radionuclides in Hanford Site Tank Wastes, HNF-SD-WM-TI-740. Lockheed Martin Hanford Company, Richland, Washington.

Mann. 1998. Hanford Low-Activity. Tank Waste Performance Assessment. DOE/RL-97-69. Rev. 0. US Department of Energy, Richland Operations Office, Richland, Washington.

Paperiello, CJ. 1997. Classification of Hanford Low-Activity Tank Waste Fraction. Letter to Jackson Kinzer, Assistant Manager, Office of Tank Waste Remediation Systems. June 1997. US Nuclear Regulatory Commission, Washington, DC.

Patello, GK and KD Wiemers. 1996. Low-Activity Waste Envelope Definitions for the TWRS Privatization Phase I Request for Proposal. PNNL-11108. Pacific Northwest National Laboratory, Richland, Washington.

Petersen, CA. 1996. Technical Basis for Classification of Low-Activity Waste Fraction from Hanford Site Tanks. WHC-DS-WM-TI-699. Rev. 1. Westinghouse Hanford Company, Richland, Washington.

PNNL. 1997. Low-Activity Waste Feed Data Quality Objectives. WIT-98-010. Rev. 0. Pacific Northwest National Laboratory, Richland, Washington.

Resource Conservation and Recovery Act of 1976. 42 USC 6901 et seq.

Welsh, TL. 1991a. Tank 241-AN-106 Characterization Results. WHC-SD-CP-TP-065. Rev. 0. Westinghouse Hanford Company, Richland, Washington.

Welsh, TL. 1991b. Tank 241-AW-101 Characterization Results. WHC-SD-WM-TRP-055. Rev. 0. Westinghouse Hanford Company, Richland, Washington.

Welsh, TL. 1993. Tank 241-AP-102 Characterization and Grout Product Test Results.

WHC-SD-WM-TRP-168. Rev. 1. Westinghouse Hanford Company, Richland, Washington.

Welsh, TL. 1997. Waste Envelope "A" Comparison, Tank 241-AN-105. HNF-SD-WM-TI-813. Rev. 0 Draft. Lockheed Martin Hanford Company, Richland, Washington. 
Wiemers, KD. 1996. Data Requirements for TWRS Privatization Characterization of Potential Low Activity Waste Feed. WHC-SD-WM-DQO-023. Rev. 0. Westinghouse Hanford Company, Richland, Washington.

Wiemers, KD, M Lerchen, M Miller, and K Meier. 1998. Regulatory Data Quality Objectives Supporting Tank Waste Remediation System Privatization Project. PNNL-12040, Rev. 0. Pacific Northwest National Laboratory, Richland Washington.. 
Appendix A

Description of Revisions 


\section{Revisions 0 - November 1997}

- The inputs to the decision logic have been updated. The implementation decision logic itself remains unchanged. In the implementation logic, available information is compared with the data requests and tank waste is sampled only when the tank waste is static and existing information is not sufficient. The twelve candidate Phase I LAW feed tanks assigned by Kirkbride (1997) are identified as high priority.

- The revised DQO provides an option for using composites rather than samples from individual tank waste strata (vertical levels). The use of composites reduces the number of samples identified for comprehensive analyses.

- Available minimum reportable levels for the analytes have been added to the revised DQO. The minimum reportable levels are based on experience with the private contractor Phase IA LAW samples (Esch 1996a, b, c).

- The solids screening has been expanded to include a limited number of solids solubility measurements.

- A new set of questions related to environmental planning adds five methods for five reference analytes. The ability to measure the reference analytes in waste matrix will be determined. The analyses to support environmental planning should be revisited on a tank-by-tank basis.

- The quality control was revised to be consistent with HASQARD.

Table A.1. Summary of Revisions to Analytes and Physical Property Measurements Lists (Page 1 of 2)

\begin{tabular}{|c|c|}
\hline Analyte & Justification \\
\hline \multicolumn{2}{|l|}{ Additions } \\
\hline $\mathbf{P}$ & $\begin{array}{l}\text { glass solubility; measurement of phosphate by ion chromatography does } \\
\text { not include insoluble phosphates. }\end{array}$ \\
\hline${ }^{125} \mathrm{Sb}$ & treatment facility design; shielding \\
\hline${ }^{231} \mathrm{~Pa}$ & ILAW performance assessment; groundwater scenario \\
\hline Organic compounds & five key analytes for environmental planning \\
\hline
\end{tabular}


Table A.1. Summary of Revisions to Analytes and Physical

Property Measurements Lists (Page 2 of 2)

\begin{tabular}{|c|c|}
\hline Analyte & Justification \\
\hline \multicolumn{2}{|l|}{ Beletions } \\
\hline $\mathrm{B}, \mathrm{Li}$ & $\begin{array}{l}\text { glassformers expected to be of low concentration in LAW feed. Will be } \\
\text { added in treatment facility }\end{array}$ \\
\hline $\mathrm{Bi}$ & $\begin{array}{l}\text { not applicable to Phase I; may be specific to SST waste from bismuth } \\
\text { phosphate process }\end{array}$ \\
\hline $\begin{array}{l}\mathrm{Ce}, \mathrm{Co}, \mathrm{Cu}, \mathrm{Mg}, \mathrm{Nd}, \mathrm{Sb} \\
\mathrm{Te}, \mathrm{Tl}, \mathrm{Be}, \mathrm{V}, \mathrm{Zn}, \mathrm{Zr}\end{array}$ & $\begin{array}{l}\text { All of these analytes were measure previously for privatization. The } \\
\text { drivers for these analytes were reexamined and technical staff determined } \\
\text { that the drivers no longer indicate a need for these analyses. }\end{array}$ \\
\hline${ }^{93} \mathrm{Zr}$ & Reevaluation of NRC guidance indicated analyte not needed for the LAW. \\
\hline${ }^{232} \mathrm{Th}$ & Analyte does not needed to be reported as individual isotope. \\
\hline${ }^{152} \mathrm{Eu}$ & ${ }^{154 / 155} \mathrm{Eu}$ are indicators for ${ }^{152} \mathrm{Eu}$. \\
\hline${ }^{90} \mathrm{Y}$ & $\begin{array}{l}\text { Analyte does not need to be reported as individual isotope for LAW } \\
\text { specification. }\end{array}$ \\
\hline Total beta & $\begin{array}{l}\text { Specific isotopes that are beta emitters are being measured and the } \\
\text { information is required by isotope, therefore the analysis is not needed. }\end{array}$ \\
\hline $\begin{array}{l}\text { Viscosity, particle size } \\
\text { distribution }\end{array}$ & $\begin{array}{l}\text { In moving the waste to the intermediate tanks, water will be added } \\
\text { and these parameters will change and cannot be easily predicted } \\
\text { based on source tank data; therefore, the measurement is not } \\
\text { required in the source tank. }\end{array}$ \\
\hline
\end{tabular}

\section{Revision 1 - September 1998}

\section{Section 1.0 -}

1) clarified the list of tanks to which the DQO applies

2) clarified the purpose of the $D Q O$ and removed environmental planning related items

3) referenced the Regulatory DQO (Wiemers et al., 1998) for all environmental planning related items

\section{Section 2.0 -}

1) clarified the problem statement and removed environmental planning related items

2) referenced the Regulatory DQO (Wiemers et al., 1998) for all environmental planning related items 


\section{Section 3.0 -}

1) added description of data requirements for each applicable subsection in the text to augment Tables 3.1 through 3.5

2) updated list of group 1 analytes per latest Privatization contract specification (DOE-RL 1998).

3) changed the order of the treatment steps to match the generic process flow

4) removed environmental planning related items

5) figures and tables were updated to match revisions in the text

\section{Section 3.1 -}

No change.

\section{Section 3.2 -}

Minor text revisions.

\section{Section 3.2.1.1 -}

1) changed solids content reference to $2 \mathrm{wt} \%$

2) added requirement and justification for analysis of Group 1 and IHLW contract species for the solids

\section{Section 3.2.1.2 -}

1) added requirement for $\mathrm{Co}$ and $\mathrm{Eu}$ analysis

2) removed requirements for analytes associated with a process design that has been dropped from consideration

\section{Section 3.2.1.3 -}

No changes.

\section{Section 3.2.1.4 -}

1) added requirement for analysis of ${ }^{99} \mathrm{Tc}$ (pertechnetate)

\section{Section 3.2.2 -}

1) added requirement for analysis of TCLP metals (40 CFR 261.24) 


\section{Section 3.2.3 -}

1) added requirement for analysis of sulfur

2) deleted requirement for analysis of mercury

\section{Section 3.3.2 -}

1) clarified the shielding data requirements that are not covered by the DQO

\section{Section 3.4 -}

1) updated section based on most recent PA

\section{Section 3.5 -}

No change.

\section{Section 3.6 -}

1) deleted entire section

\section{Section 3.7 -}

1) renumbered as Section 3.6

2) deleted reference to environmental planning analytes

\section{Section 3.8 -}

1) renumbered as Section 3.7

2) removed portions of logic associated with environmental planning/regulatory issues

\section{Section 4.0 -}

1) referenced the Regulatory DQO (Wiemers et al., 1998) for all environmental planning related items

2) clarified the list of tanks to which the DQO applies

\section{Section 5.0 -}

No changes.

\section{Section 6.0 -}

1) revised section for consistency with HLW DQO and section 7 changes 


\section{Section 7.0 -}

1) added section introduction and overview at the beginning and deleted background text

\section{Section 7.1 -}

1) clarified the text to reflect other changes in the DQO

\section{Section 7.2 -}

1) added requirement that the solids to be included for the purpose of the DQO include only those solids that are candidates for transfer as part of LAW Feed staging operations.

\section{Section 7.3 -}

1) bulletized the text for clarification

2) added requirement for recording assessment of each samples gas generation

\section{Section 7.4 -}

1) clarified text

\section{Section 7.5.1 -}

1) added discussion of TOC/oxalate analysis (moved location of text from previous revision)

2) removed requirement for duplicate analysis of the 3 subsamples

\section{Section 7.5.2 -}

No change.

\section{Section 7.5.3 -}

Revised procedures to use solid composite in testing rather than creating a separate composite for solubility screening.

\section{Section 7.6.1 -}

1) changed title to "Precision and Variability"

2) changed text to reflect analysis of 3 subsamples rather than duplicates (e.g., use of RSD, not RPD)

\section{Section 7:6.2.1 -}

1) text clarification 


\section{Section 7.6.2.2 -}

1) clarification of requirements for serial dilutions

\section{Section 7.6.2.3 -}

1) moved misplaced text on TOC to Section 7.5.1

\section{Section 7.6.4 -}

1) text clarification

\section{Section 7.7 -}

1) revision of reporting and statistical requirements

2) text clarification 
Appendix B

Assessment of Sample Number

Based on Sample Mean 
Table B.1. Mean within $10 \%$ of the Envelope Limit (Page 1 of 2)

\begin{tabular}{|c|c|c|c|c|}
\hline Alpha & Beta & $\mathrm{RSD}(\%)$ & Eirvelope Limit & $N^{*} *$ \\
\hline 0.05 & 0.05 & 5 & $10 \%$ & 4 \\
\hline 0.05 & 0.05 & 10 & $10 \%$ & 11 \\
\hline 0.05 & 0.05 & 15 & $10 \%$ & 22 \\
\hline 0.05 & 0.05 & 20 & $10 \%$ & 37 \\
\hline 0.05 & 0.05 & 25 & $10 \%$ & 57 \\
\hline 0.05 & 0.05 & 30 & $10 \%$ & 81 \\
\hline 0.05 & 0.05 & 35 & $10 \%$ & 109 \\
\hline 0.05 & 0.05 & 40 & $10 \%$ & 142 \\
\hline 0.05 & 0.05 & 45 & $10 \%$ & 179 \\
\hline 0.05 & 0.05 & 50 & $10 \%$ & 221 \\
\hline 0.05 & 0.10 & 5 & $10 \%$ & 4 \\
\hline 0.05 & 0.10 & 10 & $10 \%$ & 9 \\
\hline 0.05 & 0.10 & 15 & $10 \%$ & 17 \\
\hline 0.05 & 0.10 & 20 & $10 \%$ & 30 \\
\hline 0.05 & 0.10 & 25 & $10 \%$ & 45 \\
\hline 0.05 & 0.10 & 30 & $10 \%$ & 64 \\
\hline 0.05 & 0.10 & 35 & $10 \%$ & 87 \\
\hline 0.05 & 0.10 & 40 & $10 \%$ & 113 \\
\hline 0.05 & 0.10 & 45 & $10 \%$ & 142 \\
\hline 0.05 & 0.10 & 50 & $10 \%$ & 175 \\
\hline 0.05 & 0.20 & 5 & $10 \%$ & 3 \\
\hline 0.05 & 0.20 & 10 & $10 \%$ & 7 \\
\hline 0.05 & 0.20 & 15 & $10 \%$ & 13 \\
\hline 0.05 & 0.20 & 20 & $10 \%$ & 22 \\
\hline 0.05 & 0.20 & 25 & $10 \%$ & 33 \\
\hline 0.05 & 0.20 & 30 & $10 \%$ & 47 \\
\hline 0.05 & 0.20 & 35 & $10 \%$ & 63 \\
\hline 0.05 & 0.20 & 40 & $10 \%$ & 82 \\
\hline 0.05 & 0.20 & 45 & $10 \%$ & 103 \\
\hline 0.05 & 0.20 & 50 & $10 \%$ & 127 \\
\hline
\end{tabular}


Table B.1. Mean within 10\% of the Envelope Limit (Page 2 of 2)

\begin{tabular}{|c|c|c|c|c|}
\hline Apha & Beta & $\mathrm{RSD}(\%)$ & Envelope Limit & $\mathbf{N}$ \\
\hline 0.10 & 0.05 & 5 & $10 \%$ & 3 \\
\hline 0.10 & 0.05 & 10 & $10 \%$ & 8 \\
\hline 0.10 & 0.05 & 15 & $10 \%$ & 17 \\
\hline 0.10 & 0.05 & 20 & $10 \%$ & 29 \\
\hline 0.10 & 0.05 & 25 & $10 \%$ & 45 \\
\hline 0.10 & 0.05 & 30 & $10 \%$ & 64 \\
\hline 0.10 & 0.05 & 35 & $10 \%$ & 86 \\
\hline 0.10 & 0.05 & 40 & $10 \%$ & 112 \\
\hline 0.10 & 0.05 & 45 & $10 \%$ & 142 \\
\hline 0.10 & 0.05 & 50 & $10 \%$ & 175 \\
\hline 0.10 & 0.10 & 5 & $10 \%$ & 3 \\
\hline 0.10 & 0.10 & 10 & $10 \%$ & 7 \\
\hline 0.10 & 0.10 & 15 & $10 \%$ & 13 \\
\hline 0.10 & 0.10 & 20 & $10 \%$ & 23 \\
\hline 0.10 & 0.10 & 25 & $10 \%$ & 35 \\
\hline 0.10 & 0.10 & 30 & $10 \%$ & 49 \\
\hline 0.10 & 0.10 & 35 & $10 \%$ & 67 \\
\hline 0.10 & 0.10 & 40 & $10 \%$ & 86 \\
\hline 0.10 & 0.10 & 45 & $10 \%$ & 109 \\
\hline 0.10 & 0.10 & 50 & $10 \%$ & 134 \\
\hline 0.10 & 0.20 & 5 & $10 \%$ & 2 \\
\hline 0.10 & 0.20 & 10 & $10 \%$ & 5 \\
\hline 0.10 & 0.20 & 15 & $10 \%$ & 10 \\
\hline 0.10 & 0.20 & 20 & $10 \%$ & 16 \\
\hline 0.10 & 0.20 & 25 & $10 \%$ & 24 \\
\hline 0.10 & 0.20 & 30 & $10 \%$ & 34 \\
\hline 0.10 & 0.20 & 35 & $10 \%$ & 46 \\
\hline 0.10 & 0.20 & 40 & $10 \%$ & 60 \\
\hline 0.10 & 0.20 & 45 & $10 \%$ & 75 \\
\hline 0.10 & 0.20 & 50 & $10 \%$ & 93 \\
\hline
\end{tabular}

*: Approximate 
Table B.2. Mean within 15\% of the Envelope Limit (Page 1 of 2)

\begin{tabular}{|c|c|c|c|c|}
\hline Apha & Beta & $\operatorname{RSD}(\%)$ & Ervelope Linit & $\mathrm{N} *$ \\
\hline 0.05 & 0.05 & 5 & $15 \%$ & 3 \\
\hline 0.05 & 0.05 & 10 & $15 \%$ & 5 \\
\hline 0.05 & 0.05 & 15 & $15 \%$ & 10 \\
\hline 0.05 & 0.05 & 20 & $15 \%$ & 16 \\
\hline 0.05 & 0.05 & 25 & $15 \%$ & 24 \\
\hline 0.05 & 0.05 & 30 & $15 \%$ & 33 \\
\hline 0.05 & 0.05 & 35 & $15 \%$ & 44 \\
\hline 0.05 & 0.05 & 40 & $15 \%$ & 57 \\
\hline 0.05 & 0.05 & 45 & $15 \%$ & 72 \\
\hline 0.05 & 0.05 & 50 & $15 \%$ & 89 \\
\hline 0.05 & 0.10 & 5 & $15 \%$ & 3 \\
\hline 0.05 & 0.10 & 10 & $15 \%$ & 5 \\
\hline 0.05 & 0.10 & 15 & $15 \%$ & 8 \\
\hline 0.05 & 0.10 & 20 & $15 \%$ & 13 \\
\hline 0.05 & 0.10 & 25 & $15 \%$ & 19 \\
\hline 0.05 & 0.10 & 30 & $15 \%$ & 27 \\
\hline 0.05 & 0.10 & 35 & $15 \%$ & 36 \\
\hline 0.05 & 0.10 & 40 & $15 \%$ & 46 \\
\hline 0.05 & 0.10 & 45 & $15 \%$ & 58 \\
\hline 0.05 & 0.10 & 50 & $15 \%$ & 71 \\
\hline 0.05 & 0.20 & 5 & $15 \%$ & 2 \\
\hline 0.05 & 0.20 & 10 & $15 \%$ & 4 \\
\hline 0.05 & 0.20 & 15 & $15 \%$ & 6 \\
\hline 0.05 & 0.20 & 20 & $15 \%$ & 10 \\
\hline 0.05 & 0.20 & 25 & $15 \%$ & 14 \\
\hline 0.05 & 0.20 & 30 & $15 \%$ & 20 \\
\hline 0.05 & 0.20 & 35 & $15 \%$ & 26 \\
\hline 0.05 & 0.20 & 40 & $15 \%$ & 34 \\
\hline 0.05 & 0.20 & 45 & $15 \%$ & 42 \\
\hline 0.05 & 0.20 & 50 & $15 \%$ & 51 \\
\hline
\end{tabular}


Table B.2. Mean within $15 \%$ of the Envelope Limit (Page 2 of 2)

\begin{tabular}{|c|c|c|c|c|}
\hline Mlpha & Beta & $\mathrm{RSD}(\%)$ & Envelope Limit & $\mathbf{P}$ \\
\hline 0.10 & 0.05 & 5 & $15 \%$ & 2 \\
\hline 0.10 & 0.05 & 10 & $15 \%$ & 4 \\
\hline 0.10 & 0.05 & 15 & $15 \%$ & 8 \\
\hline 0.10 & 0.05 & 20 & $15 \%$ & 12 \\
\hline 0.10 & 0.05 & 25 & $15 \%$ & 19 \\
\hline 0.10 & 0.05 & 30 & $15 \%$ & 26 \\
\hline 0.10 & 0.05 & 35 & $15 \%$ & 35 \\
\hline 0.10 & 0.05 & 40 & $15 \%$ & 45 \\
\hline 0.10 & 0.05 & 45 & $15 \%$ & 57 \\
\hline 0.10 & 0.05 & 50 & $15 \%$ & 70 \\
\hline 0.10 & 0.10 & 5 & $15 \%$ & 2 \\
\hline 0.10 & 0.10 & 10 & $15 \%$ & 3 \\
\hline 0.10 & 0.10 & 15 & $15 \%$ & 6 \\
\hline 0.10 & 0.10 & 20 & $15 \%$ & 10 \\
\hline 0.10 & 0.10 & 25 & $15 \%$ & 15 \\
\hline 0.10 & 0.10 & 30 & $15 \%$ & 20 \\
\hline 0.10 & 0.10 & 35 & $15 \%$ & 27 \\
\hline 0.10 & 0.10 & 40 & $15 \%$ & 35 \\
\hline 0.10 & 0.10 & 45 & $15 \%$ & 44 \\
\hline 0.10 & 0.10 & 50 & $15 \%$ & 54 \\
\hline 0.10 & 0.20 & 5 & $15 \%$ & 2 \\
\hline 0.10 & 0.20 & 10 & $15 \%$ & 3 \\
\hline 0.10 & 0.20 & 15 & $15 \%$ & 5 \\
\hline 0.10 & 0.20 & 20 & $15 \%$ & 7 \\
\hline 0.10 & 0.20 & 25 & $15 \%$ & 10 \\
\hline 0.10 & 0.20 & 30 & $15 \%$ & 14 \\
\hline 0.10 & 0.20 & 35 & $15 \%$ & 19 \\
\hline 0.10 & 0.20 & 40 & $15 \%$ & 24 \\
\hline 0.10 & 0.20 & 45 & $15 \%$ & 31 \\
\hline 0.10 & 0.20 & 50 & $15 \%$ & 38 \\
\hline
\end{tabular}

*: Approximate 
Table B.3. Mean within 20\% of the Envelope Limit (Page 1 of 2)

\begin{tabular}{|c|c|c|c|c|}
\hline Apha & Beta & $\mathrm{RSD}(\%)$ & Envelope Limit & $\mathrm{N} \%$ \\
\hline 0.05 & 0.05 & 5 & $20 \%$ & 2 \\
\hline 0.05 & 0.05 & 10 & $20 \%$ & 4 \\
\hline 0.05 & 0.05 & 15 & $20 \%$ & 6 \\
\hline 0.05 & 0.05 & 20 & $20 \%$ & 9 \\
\hline 0.05 & 0.05 & 25 & $20 \%$ & 13 \\
\hline 0.05 & 0.05 & 30 & $20 \%$ & 17 \\
\hline 0.05 & 0.05 & 35 & $20 \%$ & 23 \\
\hline 0.05 & 0.05 & 40 & $20 \%$ & 30 \\
\hline 0.05 & 0.05 & 45 & $20 \%$ & 37 \\
\hline 0.05 & 0.05 & 50 & $20 \%$ & 45 \\
\hline 0.05 & 0.10 & 5 & $20 \%$ & 2 \\
\hline 0.05 & 0.10 & 10 & $20 \%$ & 3 \\
\hline 0.05 & 0.10 & 15 & $20 \%$ & 5 \\
\hline 0.05 & 0.10 & 20 & $20 \%$ & 7 \\
\hline 0.05 & 0.10 & 25 & $20 \%$ & 10 \\
\hline 0.05 & 0.10 & 30 & $20 \%$ & 14 \\
\hline 0.05 & 0.10 & 35 & $20 \%$ & 19 \\
\hline 0.05 & 0.10 & 40 & $20 \%$ & 24 \\
\hline 0.05 & 0.10 & 45 & $20 \%$ & 30 \\
\hline 0.05 & 0.10 & 50 & $20 \%$ & 36 \\
\hline 0.05 & 0.20 & 5 & $20 \%$ & 2 \\
\hline 0.05 & 0.20 & 10 & $20 \%$ & 3 \\
\hline 0.05 & 0.20 & 15 & $20 \%$ & 4 \\
\hline 0.05 & 0.20 & 20 & $20 \%$ & 6 \\
\hline 0.05 & 0.20 & 25 & $20 \%$ & 8 \\
\hline 0.05 & 0.20 & 30 & $20 \%$ & 11 \\
\hline 0.05 & 0.20 & 35 & $20 \%$ & 14 \\
\hline 0.05 & 0.20 & 40 & $20 \%$ & 18 \\
\hline 0.05 & 0.20 & 45 & $20 \%$ & 22 \\
\hline 0.05 & 0.20 & 50 & $20 \%$ & 27 \\
\hline
\end{tabular}


Table B.3. Mean within $20 \%$ of the Envelope Limit (Page 2 of 2)

\begin{tabular}{|c|c|c|c|c|}
\hline Alpha & Beta & $\mathrm{RSD}(\mathrm{O} \%)$ & Grvelope Linit & $\mathbf{N}$ \\
\hline 0.10 & 0.05 & 5 & $20 \%$ & 2 \\
\hline 0.10 & 0.05 & 10 & $20 \%$ & 3 \\
\hline 0.10 & 0.05 & 15 & $20 \%$ & 4 \\
\hline 0.10 & 0.05 & 20 & $20 \%$ & 7 \\
\hline 0.10 & 0.05 & 25 & $20 \%$ & 10 \\
\hline 0.10 & 0.05 & 30 & $20 \%$ & 14 \\
\hline 0.10 & 0.05 & 35 & $20 \%$ & 18 \\
\hline 0.10 & 0.05 & 40 & $20 \%$ & 23 \\
\hline 0.10 & 0.05 & 45 & $20 \%$ & 29 \\
\hline 0.10 & 0.05 & 50 & $20 \%$ & 36 \\
\hline 0.10 & 0.10 & 5 & $20 \%$ & 2 \\
\hline 0.10 & 0.10 & 10 & $20 \%$ & 2 \\
\hline 0.10 & 0.10 & 15 & $20 \%$ & 4 \\
\hline 0.10 & 0.10 & 20 & $20 \%$ & 6 \\
\hline 0.10 & 0.10 & 25 & $20 \%$ & 8 \\
\hline 0.10 & 0.10 & 30 & $20 \%$ & 11 \\
\hline 0.10 & 0.10 & 35 & $20 \%$ & 14 \\
\hline 0.10 & 0.10 & 40 & $20 \%$ & 18 \\
\hline 0.10 & 0.10 & 45 & $20 \%$ & 23 \\
\hline 0.10 & 0.10 & 50 & $20 \%$ & 28 \\
\hline 0.10 & 0.20 & 5 & $20 \%$ & 2 \\
\hline 0.10 & 0.20 & 10 & $20 \%$ & 2 \\
\hline 0.10 & 0.20 & 15 & $20 \%$ & 3 \\
\hline 0.10 & 0.20 & 20 & $20 \%$ & 4 \\
\hline 0.10 & 0.20 & 25 & $20 \%$ & 6 \\
\hline 0.10 & 0.20 & 30 & $20 \%$ & 8 \\
\hline 0.10 & 0.20 & 35 & $20 \%$ & 10 \\
\hline 0.10 & 0.20 & 40 & $20 \%$ & 13 \\
\hline 0.10 & 0.20 & 45 & $20 \%$ & 16 \\
\hline 0.10 & 0.20 & 50 & $20 \%$ & 19 \\
\hline
\end{tabular}

*: Approximate 
Table B.4. Mean within $25 \%$ of the Envelope Limit (Page 1 of 2)

\begin{tabular}{|c|c|c|c|c|}
\hline Apha & Beta & $\operatorname{RSD}(\%)$ & Envelope Lhinit & $N *$ \\
\hline 0.05 & 0.05 & 5 & $25 \%$ & 2 \\
\hline 0.05 & 0.05 & 10 & $25 \%$ & 3 \\
\hline 0.05 & 0.05 & 15 & $25 \%$ & 4 \\
\hline 0.05 & 0.05 & 20 & $25 \%$ & 6 \\
\hline 0.05 & 0.05 & 25 & $25 \%$ & 8 \\
\hline 0.05 & 0.05 & 30 & $25 \%$ & 11 \\
\hline 0.05 & 0.05 & 35 & $25 \%$ & 14 \\
\hline 0.05 & 0.05 & 40 & $25 \%$ & 17 \\
\hline 0.05 & 0.05 & 45 & $25 \%$ & 22 \\
\hline 0.05 & 0.05 & 50 & $25 \%$ & 26 \\
\hline 0.05 & 0.10 & 5 & $25 \%$ & 2 \\
\hline 0.05 & 0.10 & 10 & $25 \%$ & 3 \\
\hline 0.05 & 0.10 & 15 & $25 \%$ & 4 \\
\hline 0.05 & 0.10 & 20 & $25 \%$ & 5 \\
\hline 0.05 & 0.10 & 25 & $25 \%$ & 7 \\
\hline 0.05 & 0.10 & 30 & $25 \%$ & 9 \\
\hline 0.05 & 0.10 & 35 & $25 \%$ & 11 \\
\hline 0.05 & 0.10 & 40 & $25 \%$ & 14 \\
\hline 0.05 & 0.10 & 45 & $25 \%$ & 17 \\
\hline 0.05 & 0.10 & 50 & $25 \%$ & 21 \\
\hline 0.05 & 0.20 & 5 & $25 \%$ & 2 \\
\hline 0.05 & 0.20 & 10 & $25 \%$ & 2 \\
\hline 0.05 & 0.20 & 15 & $25 \%$ & 3 \\
\hline 0.05 & 0.20 & 20 & $25 \%$ & 4 \\
\hline 0.05 & 0.20 & 25 & $25 \%$ & 5 \\
\hline 0.05 & 0.20 & 30 & $25 \%$ & 7 \\
\hline 0.05 & 0.20 & 35 & $25 \%$ & 9 \\
\hline 0.05 & 0.20 & 40 & $25 \%$ & 11 \\
\hline 0.05 & 0.20 & 45 & $25 \%$ & 13 \\
\hline 0.05 & 0.20 & 50 & $25 \%$ & 16 \\
\hline
\end{tabular}


Table B.4. Mean within 25\% of the Envelope Limit (Page 2 of 2)

\begin{tabular}{|c|c|c|c|c|}
\hline Alpha & Bett & $\mathrm{RSD}(\%)$ & minvelope Limit & $\mathbf{N *}$ \\
\hline 0.10 & 0.05 & 5 & $25 \%$ & 2 \\
\hline 0.10 & 0.05 & 10 & $25 \%$ & 2 \\
\hline 0.10 & 0.05 & 15 & $25 \%$ & 3 \\
\hline 0.10 & 0.05 & 20 & $25 \%$ & 4 \\
\hline 0.10 & 0.05 & 25 & $25 \%$ & 6 \\
\hline 0.10 & 0.05 & 30 & $25 \%$ & 8 \\
\hline 0.10 & 0.05 & 35 & $25 \%$ & 11 \\
\hline 0.10 & 0.05 & 40 & $25 \%$ & 14 \\
\hline 0.10 & 0.05 & 45 & $25 \%$ & 17 \\
\hline 0.10 & 0.05 & 50 & $25 \%$ & 21 \\
\hline 0.10 & 0.10 & 5 & $25 \%$ & 1 \\
\hline 0.10 & 0.10 & 10 & $25 \%$ & 2 \\
\hline 0.10 & 0.10 & 15 & $25 \%$ & 3 \\
\hline 0.10 & 0.10 & 20 & $25 \%$ & 4 \\
\hline 0.10 & 0.10 & 25 & $25 \%$ & 5 \\
\hline 0.10 & 0.10 & 30 & $25 \%$ & 7 \\
\hline 0.10 & 0.10 & 35 & $25 \%$ & 9 \\
\hline 0.10 & 0.10 & 40 & $25 \%$ & 11 \\
\hline 0.10 & 0.10 & 45 & $25 \%$ & 13 \\
\hline 0.10 & 0.10 & 50 & $25 \%$ & 16 \\
\hline 0.10 & 0.20 & 5 & $25 \%$ & 1 \\
\hline 0.10 & 0.20 & 10 & $25 \%$ & 2 \\
\hline 0.10 & 0.20 & 15 & $25 \%$ & 2 \\
\hline 0.10 & 0.20 & 20 & $25 \%$ & 3 \\
\hline 0.10 & 0.20 & 25 & $25 \%$ & 4 \\
\hline 0.10 & 0.20 & 30 & $25 \%$ & 5 \\
\hline 0.10 & 0.20 & 35 & $25 \%$ & 6 \\
\hline 0.10 & 0.20 & 40 & $25 \%$ & 8 \\
\hline 0.10 & 0.20 & 45 & $25 \%$ & 10 \\
\hline 0.10 & 0.20 & 50 & $25 \%$ & 11 \\
\hline
\end{tabular}

*: Approximate 
Table B.5. Mean within $30 \%$ of the Envelope Limit (Page 1 of 2 )

\begin{tabular}{|c|c|c|c|c|}
\hline Alpha & Beta & $\mathrm{RSD}(\%)$ & Envelope Linit & N: \\
\hline 0.05 & 0.05 & 5 & $30 \%$ & 2 \\
\hline 0.05 & 0.05 & 10 & $30 \%$ & 2 \\
\hline 0.05 & 0.05 & 15 & $30 \%$ & 3 \\
\hline 0.05 & 0.05 & 20 & $30 \%$ & 4 \\
\hline 0.05 & 0.05 & 25 & $30 \%$ & 6 \\
\hline 0.05 & 0.05 & 30 & $30 \%$ & 7 \\
\hline 0.05 & 0.05 & 35 & $30 \%$ & 9 \\
\hline 0.05 & 0.05 & 40 & $30 \%$ & 11 \\
\hline 0.05 & 0.05 & 45 & $30 \%$ & 14 \\
\hline 0.05 & 0.05 & 50 & $30 \%$ & 17 \\
\hline 0.05 & 0.10 & 5 & $30 \%$ & 2 \\
\hline 0.05 & 0.10 & 10 & $30 \%$ & 2 \\
\hline 0.05 & 0.10 & 15 & $30 \%$ & 3 \\
\hline 0.05 & 0.10 & 20 & $30 \%$ & 4 \\
\hline 0.05 & 0.10 & 25 & $30 \%$ & 5 \\
\hline 0.05 & 0.10 & 30 & $30 \%$ & 6 \\
\hline 0.05 & 0.10 & 35 & $30 \%$ & 8 \\
\hline 0.05 & 0.10 & 40 & $30 \%$ & 9 \\
\hline 0.05 & 0.10 & 45 & $30 \%$ & 11 \\
\hline 0.05 & 0.10 & 50 & $30 \%$ & 14 \\
\hline 0.05 & 0.20 & 5 & $30 \%$ & 2 \\
\hline 0.05 & 0.20 & 10 & $30 \%$ & 2 \\
\hline 0.05 & 0.20 & 15 & $30 \%$ & 3 \\
\hline 0.05 & 0.20 & 20 & $30 \%$ & 3 \\
\hline 0.05 & 0.20 & 25 & $30 \%$ & 4 \\
\hline 0.05 & 0.20 & 30 & $30 \%$ & 5 \\
\hline 0.05 & 0.20 & 35 & $30 \%$ & 6 \\
\hline 0.05 & 0.20 & 40 & $30 \%$ & 7 \\
\hline 0.05 & 0.20 & 45 & $30 \%$ & 9 \\
\hline 0.05 & 0.20 & 50 & $30 \%$ & 10 \\
\hline
\end{tabular}


Table B.5. Mean within 30\% of the Envelope Limit (Page 2 of 2)

\begin{tabular}{|c|c|c|c|c|}
\hline Apha & Beta & $\mathrm{RSD}(\%)$ & Grvelope & $\mathrm{N}^{\prime}$ \\
\hline 0.10 & 0.05 & 5 & $30 \%$ & 1 \\
\hline 0.10 & 0.05 & 10 & $30 \%$ & 2 \\
\hline 0.10 & 0.05 & 15 & $30 \%$ & 2 \\
\hline 0.10 & 0.05 & 20 . & $30 \%$ & 3 \\
\hline 0.10 & 0.05 & 25 & $30 \%$ & 4 \\
\hline 0.10 & 0.05 & 30 & $30 \%$ & $\overline{6}$ \\
\hline 0.10 & 0.05 & 35 & $30 \%$ & 7 \\
\hline 0.10 & 0.05 & 40 & $30 \%$ & 9 \\
\hline 0.10 & 0.05 & 45 & $30 \%$ & 11 \\
\hline 0.10 & 0.05 & 50 & $30 \%$ & 13 \\
\hline 0.10 & 0.10 & 5 & $30 \%$ & 1 \\
\hline 0.10 & 0.10 & 10 & $30 \%$ & 2 \\
\hline 0.10 & 0.10 & 15 & $30 \%$ & 2 \\
\hline 0.10 & 0.10 & 20 & $30 \%$ & 3 \\
\hline 0.10 & 0.10 & 25 & $30 \%$ & 4 \\
\hline 0.10 & 0.10 & 30 & $30 \%$ & 5 \\
\hline 0.10 & 0.10 & 35 & $30 \%$ & 6 \\
\hline 0.10 & 0.10 & 40 & $30 \%$ & 7 \\
\hline 0.10 & 0.10 & 45 & $30 \%$ & 9 \\
\hline 0.10 & 0.10 & 50 & $30 \%$ & 10 \\
\hline 0.10 & 0.20 & 5 & $30 \%$ & 1 \\
\hline 0.10 & 0.20 & .10 & $30 \%$ & 2 \\
\hline 0.10 & 0.20 & 15 & $30 \%$ & 2 \\
\hline 0.10 & 0.20 & 20 & $30 \%$ & 2 \\
\hline 0.10 & 0.20 & 25 & $30 \%$ & 3 \\
\hline 0.10 & 0.20 & 30 & $30 \%$ & 4 \\
\hline 0.10 & 0.20 & 35 & $30 \%$ & 4 \\
\hline 0.10 & 0.20 & 40 & $30 \%$ & 5 \\
\hline 0.10 & 0.20 & 45 & $30 \%$ & 6 \\
\hline 0.10 & 0.20 & 50 & $30 \%$ & 7 \\
\hline
\end{tabular}

*: Approximate 
Table B.6. Mean within $40 \%$ of the Envelope Limit (Page 1 of 2)

\begin{tabular}{|c|c|c|c|c|}
\hline Alpha & Beta & $\mathrm{RSD}(\%)$ & Groclope Linut & $\mathrm{N}$ \\
\hline 0.05 & 0.05 & 5 & $40 \%$ & 2 \\
\hline 0.05 & 0.05 & 10 & $40 \%$ & 2 \\
\hline 0.05 & 0.05 & 15 & $40 \%$ & 2 \\
\hline 0.05 & 0.05 & 20 & $40 \%$ & 3 \\
\hline 0.05 & 0.05 & 25 & $40 \%$ & 3 \\
\hline 0.05 & 0.05 & 30 & $40 \%$ & 4 \\
\hline 0.05 & 0.05 & 35 & $40 \%$ & 5 \\
\hline 0.05 & 0.05 & 40 & $40 \%$ & 6 \\
\hline 0.05 & 0.05 & 45 & $40 \%$ & 7 \\
\hline 0.05 & 0.05 & 50 & $40 \%$ & 8 \\
\hline 0.05 & 0.10 & 5 & $40 \%$ & 2 \\
\hline 0.05 & 0.10 & 10 & $40 \%$ & 2 \\
\hline 0.05 & 0.10 & 15 & $40 \%$ & 2 \\
\hline 0.05 & 0.10 & 20 & $40 \%$ & 3. \\
\hline 0.05 & 0.10 & 25 & $40 \%$ & 3 \\
\hline 0.05 & 0.10 & 30 & $40 \%$ & 4 \\
\hline 0.05 & 0.10 & 35 & $40 \%$ & 4 \\
\hline 0.05 & 0.10 & 40 & $40 \%$ & 5 \\
\hline 0.05 & 0.10 & 45 & $40 \%$ & 6 \\
\hline 0.05 & 0.10 & 50 & $40 \%$ & 7 \\
\hline 0.05 & 0.20 & 5 & $40 \%$ & 2 \\
\hline 0.05 & 0.20 & 10 & $40 \%$ & 2 \\
\hline 0.05 & 0.20 & 15 & $40 \%$ & 2 \\
\hline 0.05 & 0.20 & 20 & $40 \%$ & 2 \\
\hline 0.05 & 0.20 & 25 & $40 \%$ & 3 \\
\hline 0.05 & 0.20 & 30 & $40 \%$ & 3 \\
\hline 0.05 & 0.20 & 35 & $40 \%$ & 4 \\
\hline 0.05 & 0.20 & 40 & $40 \%$ & 4 \\
\hline 0.05 & 0.20 & 45 & $40 \%$ & 5 \\
\hline 0.05 & 0.20 & 50 & $40 \%$ & 5 \\
\hline
\end{tabular}


Table B.6. Mean within $40 \%$ of the Envelope Limit (Page 2 of 2)

\begin{tabular}{|c|c|c|c|c|}
\hline Alpha & Beta & $\mathrm{RSD}(\%)$ & Envelope 1 rinit & $\mathrm{N}^{*}$ \\
\hline 0.10 & 0.05 & 5 & $40 \%$ & 1 \\
\hline 0.10 & 0.05 & 10 & $40 \%$ & 2 \\
\hline 0.10 & 0.05 & 15 & $40 \%$ & 2 \\
\hline 0.10 & 0.05 & 20 & $40 \%$ & 2 \\
\hline 0.10 & 0.05 & 25 & $40 \%$ & 3 \\
\hline 0.10 & 0.05 & 30 & $40 \%$ & 3 \\
\hline 0.10 & 0.05 & 35 & $40 \%$ & 4 \\
\hline 0.10 & 0.05 & 40 & $40 \%$ & 4 \\
\hline 0.10 & 0.05 & 45 & $40 \%$ & 5 \\
\hline 0.10 & 0.05 & 50 & $40 \%$ & 6 \\
\hline 0.10 & 0.10 & 5 & $40 \%$ & 1 \\
\hline 0.10 & 0.10 & 10 & $40 \%$ & 1 \\
\hline 0.10 & 0.10 & 15 & $40 \%$ & 2 \\
\hline 0.10 & 0.10 & 20 & $40 \%$ & 2 \\
\hline 0.10 & 0.10 & 25 & $40 \%$ & 2 \\
\hline 0.10 & 0.10 & 30 & $40 \%$ & 3 \\
\hline 0.10 & 0.10 & 35 & $40 \%$ & 3 \\
\hline 0.10 & 0.10 & 40 & $40 \%$ & 4 \\
\hline 0.10 & 0.10 & 45 & $40 \%$ & 4 \\
\hline 0.10 & 0.10 & 50 & $40 \%$ & 5 \\
\hline 0.10 & 0.20 & 5 & $40 \%$ & 1 \\
\hline 0.10 & 0.20 & 10 & $40 \%$ & 1 \\
\hline 0.10 & 0.20 & 15 & $40 \%$ & 2 \\
\hline 0.10 & 0.20 & 20 & $40 \%$ & 2 \\
\hline 0.10 & 0.20 & 25 & $40 \%$ & 2 \\
\hline 0.10 & 0.20 & 30 & $40 \%$ & 2 \\
\hline 0.10 & 0.20 & 35 & $40 \%$ & 3 \\
\hline 0.10 & 0.20 & 40 & $40 \%$ & 3 \\
\hline 0.10 & 0.20 & 45 & $40 \%$ & 3 \\
\hline 0.10 & 0.20 & 50 & $40 \%$ & 4 \\
\hline
\end{tabular}

*: Approximate 
Table B.7. Mean within $50 \%$ of the Envelope Limit (Page 1 of 2)

\begin{tabular}{|c|c|c|c|c|}
\hline Apha & Beta & $\mathrm{RSD}(\%)$ & Envelope Limit & $\mathrm{N} *$ \\
\hline 0.05 & 0.05 & 5 & $50 \%$ & 2 \\
\hline 0.05 & 0.05 & 10 & $50 \%$ & 2 \\
\hline 0.05 & 0.05 & 15 & $50 \%$ & 2 \\
\hline 0.05 & 0.05 & 20 & $50 \%$ & 2 \\
\hline 0.05 & 0.05 & 25 & $50 \%$ & 3 \\
\hline $0: 05$ & 0.05 & 30 & $50 \%$ & 3 \\
\hline 0.05 & 0.05 & 35 & $50 \%$ & 3 \\
\hline 0.05 & 0.05 & 40 & $50 \%$ & 4 \\
\hline 0.05 & 0.05 & 45 & $50 \%$ & 4 \\
\hline 0.05 & 0.05 & 50 & $50 \%$ & 5 \\
\hline 0.05 & 0.10 & 5 & $50 \%$ & 2 \\
\hline 0.05 & 0.10 & 10 & $50 \%$ & 2 \\
\hline 0.05 & 0.10 & 15 & $50 \%$ & 2 \\
\hline 0.05 & 0.10 & 20 & $50 \%$ & 2 \\
\hline 0.05 & 0.10 & 25 & $50 \%$ & 2 \\
\hline 0.05 & 0.10 & 30 & $50 \%$ & 3 \\
\hline 0.05 & 0.10 & 35 & $50 \%$ & 3 \\
\hline 0.05 & 0.10 & 40 & $50 \%$ & 3 \\
\hline 0.05 & 0.10 & 45 & $50 \%$ & 4 \\
\hline 0.05 & 0.10 & 50 & $50 \%$ & 4 \\
\hline 0.05 & 0.20 & 5 & $50 \%$ & 2 \\
\hline 0.05 & 0.20 & 10 & $50 \%$ & 2 \\
\hline 0.05 & 0.20 & 15 & $50 \%$ & 2 \\
\hline 0.05 & 0.20 & 20 & $50 \%$ & 2 \\
\hline 0.05 & 0.20 & 25 & $50 \%$ & 2 \\
\hline 0.05 & 0.20 & 30 & $50 \%$ & 2 \\
\hline 0.05 & 0.20 & 35 & $50 \%$ & 3 \\
\hline 0.05 & 0.20 & 40 & $50 \%$ & 3 \\
\hline 0.05 & 0.20 & 45 & $50 \%$ & 3 \\
\hline 0.05 & 0.20 & 50 & $50 \%$ & 3 \\
\hline
\end{tabular}


Table B.7. Mean within $50 \%$ of the Envelope Limit (Page 2 of 2)

\begin{tabular}{|c|c|c|c|c|}
\hline Alpha & Beta & $\operatorname{RSD}(\%)$ & Envelope Limit & $N *$ \\
\hline 0.10 & 0.05 & 5 & $50 \%$ & 1 \\
\hline 0.10 & 0.05 & 10 & $50 \%$ & 1 \\
\hline 0.10 & 0.05 & 15 & $50 \%$ & 2 \\
\hline 0.10 & 0.05 & 20 & $50 \%$ & 2 \\
\hline 0.10 & 0.05 & 25 & $50 \%$ & 2 \\
\hline 0.10 & 0.05 & 30 & $50 \%$ & 2 \\
\hline 0.10 & 0.05 & 35 & $50 \%$ & 2 \\
\hline 0.10 & 0.05 & 40 & $50 \%$ & 3 \\
\hline 0.10 & 0.05 & 45 & $50 \%$ & 3 \\
\hline 0.10 & 0.05 & 50 & $50 \%$ & 3 \\
\hline 0.10 & 0.10 & 5 & $50 \%$ & 1 \\
\hline 0.10 & 0.10 & 10 & $50 \%$ & 1 \\
\hline 0.10 & 0.10 & 15 & $50 \%$ & 1 \\
\hline 0.10 & 0.10 & 20 & $50 \%$ & 2 \\
\hline 0.10 & 0.10 & 25 & $50 \%$ & 2 \\
\hline 0.10 & 0.10 & 30 & $50 \%$ & 2 \\
\hline 0.10 & 0.10 & 35 & $50 \%$ & 2 \\
\hline 0.10 & 0.10 & 40 & $50 \%$ & 2 \\
\hline 0.10 & 0.10 & 45 & $50 \%$ & 3 \\
\hline 0.10 & 0.10 & 50 & $50 \%$ & 3 \\
\hline 0.10 & 0.20 & 5 & $50 \%$ & 1 \\
\hline 0.10 & 0.20 & 10 & $50 \%$ & 1 \\
\hline 0.10 & 0.20 & 15 & $50 \%$ & 1 \\
\hline 0.10 & 0.20 & 20 & $50 \%$ & 2 \\
\hline 0.10 & 0.20 & 25 & $50 \%$ & 2 \\
\hline 0.10 & 0.20 & 30 & $50 \%$ & 2 \\
\hline 0.10 & 0.20 & 35 & $50 \%$ & 2 \\
\hline 0.10 & 0.20 & 40 & $50 \%$ & 2 \\
\hline 0.10 & 0.20 & 45 & $50 \%$ & 2 \\
\hline 0.10 & 0.20 & 50 & $50 \%$ & 2 \\
\hline
\end{tabular}

*: Approximate 
Table B.8. Mean within $60 \%$ of the Envelope Limit (Page 1 of 2)

\begin{tabular}{|c|c|c|c|c|}
\hline Alpha & Beta & $\mathrm{RSD}(\%)$ & Envelope & $\mathrm{N} *$ \\
\hline 0.05 & 0.05 & 5 & $60 \%$ & 2 \\
\hline 0.05 & 0.05 & 10 & $60 \%$ & 2 \\
\hline 0.05 & 0.05 & 15 & $60 \%$ & 2 \\
\hline 0.05 & 0.05 & 20 & $60 \%$ & 2 \\
\hline 0.05 & 0.05 & 25 & $60 \%$ & 2 \\
\hline 0.05 & 0.05 & 30 & $60 \%$ & 2 \\
\hline 0.05 & 0.05 & 35 & $60 \%$ & 2 \\
\hline 0.05 & 0.05 & 40 & $60 \%$ & 3 \\
\hline 0.05 & 0.05 & 45 & $60 \%$ & 3 \\
\hline 0.05 & 0.05 & 50 & $60 \%$ & 3 \\
\hline 0.05 & 0.10 & 5 & $60 \%$ & 2 \\
\hline 0.05 & 0.10 & 10 & $60 \%$ & 2. \\
\hline 0.05 & 0.10 & 15 & $60 \%$ & 2 \\
\hline 0.05 & 0.10 & 20 & $60 \%$ & 2 \\
\hline 0.05 & 0.10 & 25 & $60 \%$ & 2 \\
\hline 0.05 & 0.10 & 30 & $60 \%$ & 2 \\
\hline 0.05 & 0.10 & 35 & $60 \%$ & 2 \\
\hline 0.05 & 0.10 & 40 & $60 \%$ & 2 \\
\hline 0.05 & 0.10 & 45 & $60 \%$ & 3 \\
\hline 0.05 & 0.10 & 50 & $60 \%$ & 3 \\
\hline 0.05 & 0.20 & 5 & $60 \%$ & 2 \\
\hline 0.05 & 0.20 & 10 & $60 \%$ & 2 \\
\hline 0.05 & 0.20 & 15 & $60 \%$ & 2 \\
\hline 0.05 & 0.20 & 20 & $60 \%$ & 2 \\
\hline 0.05 & 0.20 & 25 & $60 \%$ & 2 \\
\hline 0.05 & 0.20 & 30 & $60 \%$ & 2 \\
\hline 0.05 & 0.20 & 35 & $60 \%$ & 2 \\
\hline 0.05 & 0.20 & 40 & $60 \%$ & 2 \\
\hline 0.05 & 0.20 & 45 & $60 \%$ & 2 \\
\hline 0.05 & 0.20 & 50 & $60 \%$ & 3 \\
\hline
\end{tabular}


Table B.8. Mean within $60 \%$ of the Envelope Limit (Page 2 of 2)

\begin{tabular}{|c|c|c|c|c|}
\hline Alpha & Beta & $\mathrm{RSD}(\%)$ & Grvelope Limit & N* \\
\hline 0.10 & 0.05 & 5 & $60 \%$ & 1 \\
\hline 0.10 & 0.05 & 10 & $60 \%$ & 1 \\
\hline 0.10 & 0.05 & 15 & $60 \%$ & 1 \\
\hline 0.10 & 0.05 & 20 & $60 \%$ & 1 \\
\hline 0.10 & 0.05 & 25 & $60 \%$ & 2 \\
\hline 0.10 & 0.05 & 30 & $60 \%$ & 2 \\
\hline 0.10 & 0.05 & 35 & $60 \%$ & 2 \\
\hline 0.10 & 0.05 & 40 & $60 \%$ & 2 \\
\hline 0.10 & 0.05 & 45 & $60 \%$ & 2 \\
\hline 0.10 & 0.05 & 50 & $60 \%$ & 2 \\
\hline 0.10 & 0.10 & 5 & $60 \%$ & 1 \\
\hline 0.10 & 0.10 & 10 & $60 \%$ & 1 \\
\hline 0.10 & 0.10 & 15 & $60 \%$ & 1 \\
\hline 0.10 & 0.10 & 20 & $60 \%$ & 1 \\
\hline 0.10 & 0.10 & 25 & $60 \%$ & 2 \\
\hline 0.10 & 0.10 & 30 & $60 \%$ & 2 \\
\hline 0.10 & 0.10 & 35 & $60 \%$ & 2 \\
\hline 0.10 & 0.10 & 40 & $60 \%$ & 2 \\
\hline 0.10 & 0.10 & 45 & $60 \%$ & 2 \\
\hline 0.10 & 0.10 & 50 & $60 \%$ & 2 \\
\hline 0.10 & 0.20 & 5 & $60 \%$ & 1 \\
\hline 0.10 & 0.20 & 10 & $60 \%$ & 1 \\
\hline 0.10 & 0.20 & 15 & $60 \%$ & 1 \\
\hline 0.10 & 0.20 & 20 & $60 \%$ & 1 \\
\hline 0.10 & 0.20 & 25 & $60 \%$ & 1 \\
\hline 0.10 & 0.20 & 30 & $60 \%$ & 2 \\
\hline 0.10 & 0.20 & 35 & $60 \%$ & 2 \\
\hline 0.10 & 0.20 & 40 & $60 \%$ & 2 \\
\hline 0.10 & 0.20 & 45 & $60 \%$ & 2 \\
\hline 0.10 & 0.20 & 50 & $60 \%$ & 2 \\
\hline
\end{tabular}

*: Approximate 
Table B.9. Mean within $80 \%$ of the Envelope Limit (Page 1 of 3)

\begin{tabular}{|c|c|c|c|c|}
\hline Alpha & Beta & $\operatorname{RSD}(\%)$ & $40 \%$ Envelope l imit & $\mathrm{N}$ \\
\hline 0.05 & 0.05 & 40 & $80 \%$ & 2 \\
\hline 0.05 & 0.05 & 45 & $80 \%$ & 2 \\
\hline 0.05 & 0.05 & 50 & $80 \%$ & 2 \\
\hline 0.05 & 0.05 & 60 & $80 \%$ & 2 \\
\hline 0.05 & 0.05 & 70 & $80 \%$ & 2 \\
\hline 0.05 & 0.05 & 80 & $80 \%$ & 2 \\
\hline 0.05 & 0.05 & 90 & $80 \%$ & 2 \\
\hline 0.05 & 0.05 & 100 & $80 \%$ & 3 \\
\hline 0.05 & 0.05 & 150 & $80 \%$ & 3 \\
\hline 0.05 & 0.05 & 175 & $80 \%$ & 4 \\
\hline 0.05 & 0.05 & 200 & $80 \%$ & 5 \\
\hline 0.05 & 0.10 & 40 & $80 \%$ & 2 \\
\hline 0.05 & 0.10 & 45 & $80 \%$ & 2 \\
\hline 0.05 & 0.10 & 50 & $80 \%$ & 2 \\
\hline 0.05 & 0.10 & 60 & $80 \%$ & 2 \\
\hline 0.05 & 0.10 & 70 & $80 \%$ & 2 \\
\hline 0.05 & 0.10 & 80 & $80 \%$ & 2 \\
\hline 0.05 & 0.10 & 90 & $80 \%$ & 2 \\
\hline 0.05 & 0.10 & 100 & $80 \%$ & 2 \\
\hline 0.05 & 0.10 & 150 & $80 \%$ & 3 \\
\hline 0.05 & 0.10 & 175 & $80 \%$ & 3 \\
\hline 0.05 & 0.10 & 200 & $80 \%$ & 4 \\
\hline
\end{tabular}


Table B.9. Mean within $80 \%$ of the Envelope Limit (Page 2 of 3)

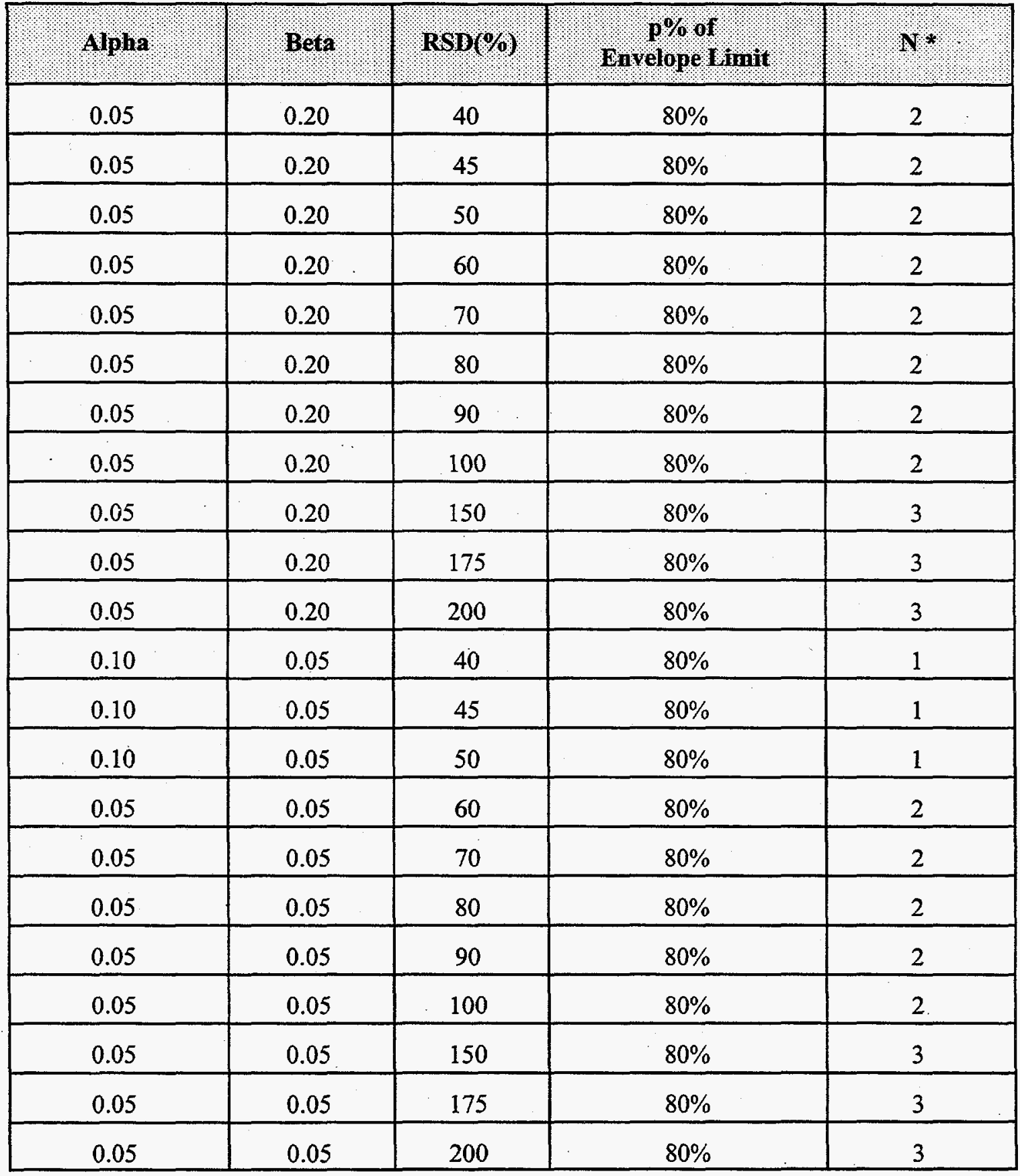


Table B.9. Mean within $80 \%$ of the Envelope Limit (Page 3 of 3)

\begin{tabular}{|c|c|c|c|c|}
\hline Apha & Beta & $\mathrm{RSD}(\%)$ & Envelope L Gimit & $\mathrm{N} *$ \\
\hline 0.10 & 0.10 & 40 & $80 \%$ & 1 \\
\hline 0.10 & 0.10 & 45 & $80 \%$ & 1 \\
\hline 0.10 & 0.10 & 50 & $80 \%$ & 1 \\
\hline 0.10 & 0.10 & 60 & $80 \%$ & 1 \\
\hline 0.10 & 0.10 & 70 & $80 \%$ & 2 \\
\hline 0.10 & 0.10 & 80 & $80 \%$ & 2 \\
\hline 0.10 & 0.10 & 90 & $80 \%$ & 2 \\
\hline 0.10 & 0.10 & 100 & $80 \%$ & 2 \\
\hline 0.10 & 0.10 & 150 & $80 \%$ & 2 \\
\hline 0.10 & 0.10 & 175 & $80 \%$ & 3 \\
\hline 0.10 & 0.10 & 200 & $80 \%$ & 3 \\
\hline 0.10 & 0.20 & 40 & $80 \%$ & 1 \\
\hline 0.10 & 0.20 & 45 & $80 \%$ & 1 \\
\hline 0.10 & 0.20 & 50 & $80 \%$ & 1 \\
\hline 0.10 & 0.20 & 60 & $80 \%$ & 1 \\
\hline 0.10 & 0.20 & 70 & $80 \%$ & 1 \\
\hline 0.10 & 0.20 & 80 & $80 \%$ & 2 \\
\hline 0.10 & 0.20 & 90 & $80 \%$ & 2 \\
\hline 0.10 & 0.20 & 100 & $80 \%$ & 2 \\
\hline 0.10 & 0.20 & 150 & $80 \%$ & 2 \\
\hline 0.10 & 0.20 & 175 & $80 \%$ & 2 \\
\hline 0.10 & 0.20 & 200 & $80 \%$ & 2 \\
\hline
\end{tabular}

*: Approximate 
Table B.10. Mean within $90 \%$ of the Envelope Limit (Page 1 of 3)

\begin{tabular}{|c|c|c|c|c|}
\hline Alpha & Beta & $\mathrm{RSD}(\%)$ & $\mathrm{p} \%$ of Envelope rimit & $\mathrm{N} *$ \\
\hline 0.05 & 0.05 & 60 & $90 \%$ & 2 \\
\hline 0.05 & 0.05 & 70 & $90 \%$ & 2 \\
\hline 0.05 & 0.05 & 80 & $90 \%$ & 2 \\
\hline 0.05 & 0.05 & 90 & $90 \%$ & 2 \\
\hline 0.05 & 0.05 & 100 & $90 \%$ & 2 \\
\hline 0.05 & 0.05 & 150 & $90 \%$ & 2 \\
\hline 0.05 & 0.05 & 175 & $90 \%$ & 2 \\
\hline 0.05 & 0.05 & 200 & $90 \%$ & 2 \\
\hline 0.05 & 0.05 & 300 & $90 \%$ & 3 \\
\hline 0.05 & 0.05 & 400 & $90 \%$ & 4 \\
\hline 0.05 & 0.05 & 500 & $90 \%$ & 5 \\
\hline 0.05 & 0.10 & 60 & $90 \%$ & 2 \\
\hline 0.05 & 0.10 & 70 & $90 \%$ & 2 \\
\hline 0.05 & 0.10 & 80 & $90 \%$ & 2 \\
\hline 0.05 & 0.10 & 90 & $90 \%$ & 2 \\
\hline 0.05 & 0.10 & 100 & $90 \%$ & 2 \\
\hline 0.05 & 0.10 & 150 & $90 \%$ & 2 \\
\hline 0.05 & 0.10 & 175 & $90 \%$ & 2 \\
\hline 0.05 & 0.10 & 200 & $90 \%$ & 2 \\
\hline 0.05 & 0.10 & 300 & $90 \%$ & 3 \\
\hline 0.05 & 0.10 & 400 & $90 \%$ & 4 \\
\hline 0.05 & 0.10 & 500 & $90 \%$ & 4 \\
\hline
\end{tabular}


Table B.10. Mean within $90 \%$ of the Envelope Limit (Page 2 of 3 )

\begin{tabular}{|c|c|c|c|c|}
\hline Alpha & Beta & $\mathrm{RSD}(\%)$ & p\% of Envelope 1 imit & $\mathrm{N} *$ \\
\hline 0.05 & 0.20 & 60 & $90 \%$ & 2 \\
\hline 0.05 & 0.20 & 70 & $90 \%$ & 2 \\
\hline 0.05 & 0.20 & 80 & $90 \%$ & 2 \\
\hline 0.05 & 0.20 & 90 & $90 \%$ & 2 \\
\hline 0.05 & 0.20 & 100 & $90 \%$ & 2 \\
\hline 0.05 & 0.20 & 150 & $90 \%$ & 2 \\
\hline 0.05 & 0.20 & 175 & $90 \%$ & 2 \\
\hline 0.05 & 0.20 & 200 & $90 \%$ & 2 \\
\hline 0.05 & 0.20 & 300 & $90 \%$ & 3 \\
\hline 0.05 & 0.20 & 400 & $90 \%$ & 3 \\
\hline 0.05 & 0.20 & 500 & $90 \%$ & 4 \\
\hline 0.10 & 0.05 & 60 & $90 \%$ & 1 \\
\hline 0.10 & 0.05 & 70 & $90 \%$ & 1 \\
\hline 0.10 & 0.05 & 80 & $90 \%$ & 1 \\
\hline 0.10 & 0.05 & 90 & $90 \%$ & 1 \\
\hline 0.10 & 0.05 & 100 & $90 \%$ & 1 \\
\hline 0.10 & 0.05 & 150 & $90 \%$ & 2 \\
\hline 0.10 & 0.05 & 175 & $90 \%$ & 2 \\
\hline 0.10 & 0.05 & 200 & $90 \%$ & 2 \\
\hline 0.10 & 0.05 & 300 & $90 \%$ & 2 \\
\hline 0.10 & 0.05 & 400 & $90 \%$ & 3 \\
\hline 0.10 & 0.05 & 500 & $90 \%$ & 4 \\
\hline
\end{tabular}


Table B.10. Mean within 90\% of the Envelope Limit (Page 3 of 3)

\begin{tabular}{|c|c|c|c|c|}
\hline Alpha & Beta & $\mathrm{RSD}(\%)$ & p\% of Envelope Limit & N* \\
\hline 0.10 & 0.10 & 60 & $90 \%$ & 1 \\
\hline 0.10 & 0.10 & 70 & $90 \%$ & 1 \\
\hline 0.10 & 0.10 & 80 & $90 \%$ & 1 \\
\hline 0.10 & 0.10 & 90 & $90 \%$ & 1 \\
\hline 0.10 & 0.10 & 100 & $90 \%$ & 1 \\
\hline 0.10 & 0.10 & 150 & $90 \%$ & 2 \\
\hline 0.10 & 0.10 & 175 & $90 \%$ & 2 \\
\hline 0.10 & 0.10 & 200 & $90 \%$ & 2 \\
\hline 0.10 & 0.10 & 300 & $90 \%$ & 2 \\
\hline 0.10 & 0.10 & 400 & $90 \%$ & 3 \\
\hline 0.10 & 0.10 & 500 & $90 \%$ & 3 \\
\hline 0.10 & 0.20 & 60 & $90 \%$ & 1 \\
\hline 0.10 & 0.20 & 70 & $90 \%$ & 1 \\
\hline 0.10 & 0.20 & 80 & $90 \%$ & 1 \\
\hline 0.10 & 0.20 & 90 & $90 \%$ & 1 \\
\hline 0.10 & 0.20 & 100 & $90 \%$ & 1 \\
\hline 0.10 & 0.20 & 150 & $90 \%$ & 1 \\
\hline 0.10 & 0.20 & 175 & $90 \%$ & 1 \\
\hline 0.10 & 0.20 & 200 & $90 \%$ & 2 \\
\hline 0.10 & 0.20 & 300 & $90 \%$ & 2 \\
\hline 0.10 & 0.20 & 400 & $90 \%$ & 2 \\
\hline 0.10 & 0.20 & 500 & $90 \%$ & 3 \\
\hline
\end{tabular}

*: Approximate 
Appendix C

Statistical Methodology 
1. For each analyte from then composite sub-sample results compute the mean concentration $(\hat{\mu})$, standard deviation of the mean $\left(s_{\hat{\mu}}\right)=s / \sqrt{n}$, and the RSD associated with the mean $\left(\operatorname{RSD}(\hat{\mu}) ; s_{\hat{\mu}} / \hat{\mu} \times 100\right)$. Both $s_{\hat{\mu}}$ and $\left(s_{\hat{\mu}} / \hat{\mu} \times 100\right)$ represent the random variability associated with the analytical measurements.

2. For each analyte obtain the results of the spike and reference standards analyzed in conjunction with the composite subsamples. Calculate the mean percent recovery $(z)$ and the standard deviation associated with the mean recovery $\left(s_{z} / \sqrt{n}\right)$ for each analyte from the spike results. The bias of the analytical measurement is estimated using $|100-z|$. The systematic variability is estimated using the larger of $\left(s_{z} / \sqrt{n}\right)$ or $|100-z|$.

If spike results are not available or not possible then use either the reference standards results or the serial dilution results. If reference standards results are used then the formulas listed in the first paragraph are used to estimate the systematic variability. If serial dilution results are used then the variability between the different dilution results is used to estimate the systematic variability.

3. For each analyte convert the data from standard laboratory units $(\mu \mathrm{g} / \mathrm{mL}$ or $\mu \mathrm{Ci} / \mathrm{mL})$ to privatization units (mole analyte/mole $\mathrm{Na}$ or $\mathrm{Bq}$ analyte/mole $\mathrm{Na}$ ).

4. For each analyte compute the $(\mathrm{R})$ ratio mole analyte/mole $\mathrm{Na}$ or Becquerel analyte/mole $\mathrm{Na}$. The estimate of $\mathrm{R}(\hat{R})$ is the ratio $\mathrm{X} / \mathrm{Y}$ where $\mathrm{X}$ is the mean concentration of an analyte (e.g., moles $/ \mathrm{L}$ ) and $\mathrm{Y}$ is the mean $\mathrm{Na}$ concentration (e.g., moles $/ \mathrm{L}$ ).

5. The random variability (in terms of RSD) associated with $\hat{R}$ is approximated by $\left([\mathrm{RSD}(\mathrm{X})]^{2}+[\mathrm{RSD}(\mathrm{Y})]^{2}\right)^{0.5}$. This assumes that $\mathrm{X}$ and $\mathrm{Y}$ are independent. The degrees of freedom, $d f$, are approximate, they will be the smaller of the $d f$ for the estimate of the variance (random) of the numerator or of the denominator.

6. The total variability (in terms of RSD) associated with $\hat{\mathrm{R}}$ is approximated by $\left(\left([\operatorname{RSD}(\mathrm{X})]^{2}+\left(\mathrm{X}_{\text {sys }}\right)^{2}\right)+\left([\operatorname{RSD}(\mathrm{Y})]^{2}+\left(\mathrm{Y}_{\text {sys }}\right)^{2}\right)^{0.5}\right.$ where $\mathrm{X}_{\text {sys }}$ and $\mathrm{Y}_{\text {sys }}$ represent the systematic variability estimates (\%) determined in item 2 above.

7. For each analyte compute the upper limit of an approximate one-sided $95 \%$ confidence interval (CI) for $\hat{\mathrm{R}}$ using the random variability estimate (determined in item 5). The UL of an approximate 95 percent $\mathrm{CI}$ for the concentration mean uses the following equation where $\mathrm{t}_{(\mathrm{df}, 0.05)}$ is the quantile from Student's $t$ distribution with $d f$ degrees of freedom (determined in item 5).

$$
\hat{\mathbf{R}}+\mathbf{t}_{(\mathrm{df}, 0.05)} \times \mathrm{S}_{\hat{\mathrm{R}}} \text {, where } \mathrm{S}_{\hat{\mathrm{R}}}=\operatorname{RSD}(\hat{\mathrm{R}}) \times \hat{\mathrm{R}}
$$

8. For each analyte compute the upper limit of an approximate one-sided $95 \%$ confidence interval (CI) for $\hat{\mathrm{R}}$ using the total variability estimate (determined in item 6). The UL of an approximate 95 percent $\mathrm{CI}$ for the concentration mean uses the following equation where $t_{(\mathrm{dr}, 0.05)}$ is the quantile from Student's $t$ distribution with $d f$ degrees of freedom (determined in item 5 ).

$$
\hat{R}+t_{(d f, 0.05)} \times S_{\hat{R}} \text {, where } S_{\hat{R}}=\operatorname{RSD}(\hat{R}) \times \hat{R}
$$


9. For each analyte compare the "ratio", the upper limit of an approximate $95 \%$ CI for the ratio based on the random variability, and the upper limit of an approximate $95 \% \mathrm{CI}$ for the ratio based on the total variability to the envelope specification limit.

a. If the upper limit for the "mean ratio" based on the total variability is less than the envelope specification limit for that analyte, then no further action is required.

b. If the upper limit for the "mean ratio" based on the total variability is greater than the envelope specification limit for an analyte but the upper limit for the "mean ratio" based on the random variability is less than the envelope specification limit for an analyte and the average spike recovery was greater than $100 \%$, then no further action is required.

c. If the upper limit for the "mean ratio" based on the total variability is greater than the envelope specification limit for an analyte but the upper limit for the "mean ratio" based on the random variability is less than the envelope specification limit for an analyte and the average spike recovery was less than $100 \%$, then additional investigations into the data analysis (analytical) are required.

1. Verify the laboratory calculations.

2. Investigate the reason(s) for the low spike (reference standard) recoveries.

d. If both the upper limit for the "mean ratio" based on the total variability and the upper limit for the "mean ratio" based on the random variability are greater than the envelope specification limit for an analyte but the "mean ratio" is less than the envelope specification limit for an analyte, then additional investigations into the data analysis (analytical and statistical) are required.

1. Verify the laboratory calculations. Check and make sure the spike recoveries and the reference standard recoveries are within the specified limits.

2. For each analyte compute the approximate probability that the ratio will exceed the envelope specification limit; i.e., compute $t^{\prime}=(E L-R) / S_{R}$ and determine the probability of exceeding $t^{\prime}$ using the $t$-distribution with $d f$ degrees of freedom.

3. Use the observed mean and RSD to estimate the number of additional composite subsamples that would be necessary to increase the certainty of the envelope comparison to the desired level using the tables in Appendix B. Assess the selection of the appropriate probability of Type I and Type II errors to be used in calculations.

e. If the "mean ratio" is greater than the envelope specification limit for an analyte, then the analyte is flagged. No additional investigations into the data analysis (analytical and statistical) are required. 


\section{Distribution}

No. of

Copies

ONSITE

B\&W Protec

T.L. Welsh

T4-40

7 DOE Richland Operations Office

N. R. Brown

$\mathrm{A} 0-21$

R. Carreon

N. C. Welliver (5)

Flour Daniel Northwest

F. M. Mann

R1-04 $\mathrm{A} 0-21$

$\mathrm{A} 0-21$
No. of

Copies

5 Lockheed Martin Hanford Co.

D. L. Banning

R2-12

J. M. Conner

R2-11

T. A. Hu

R2-11

J. Jo

R2-12

J. H. Rasmussen

$\mathrm{R} 2-12$

18 Pacific Northwest National Laboratory

J. L. Kovach (TAP)

A0-21

G. K. Patello

K6-24

B. A. Reynolds

A0-21

M. J. Truex (3)

K2-10

K. D. Wiemers (5)

A0-21

Information Release Office (7)

K1-06

Distr.1 